Prepared in cooperation with the West Virginia Conservation Agency and the Eastern Panhandle Conservation District

\title{
Hydrogeology, Aquifer Geochemistry, and Ground-Water Quality in Morgan County, West Virginia
}

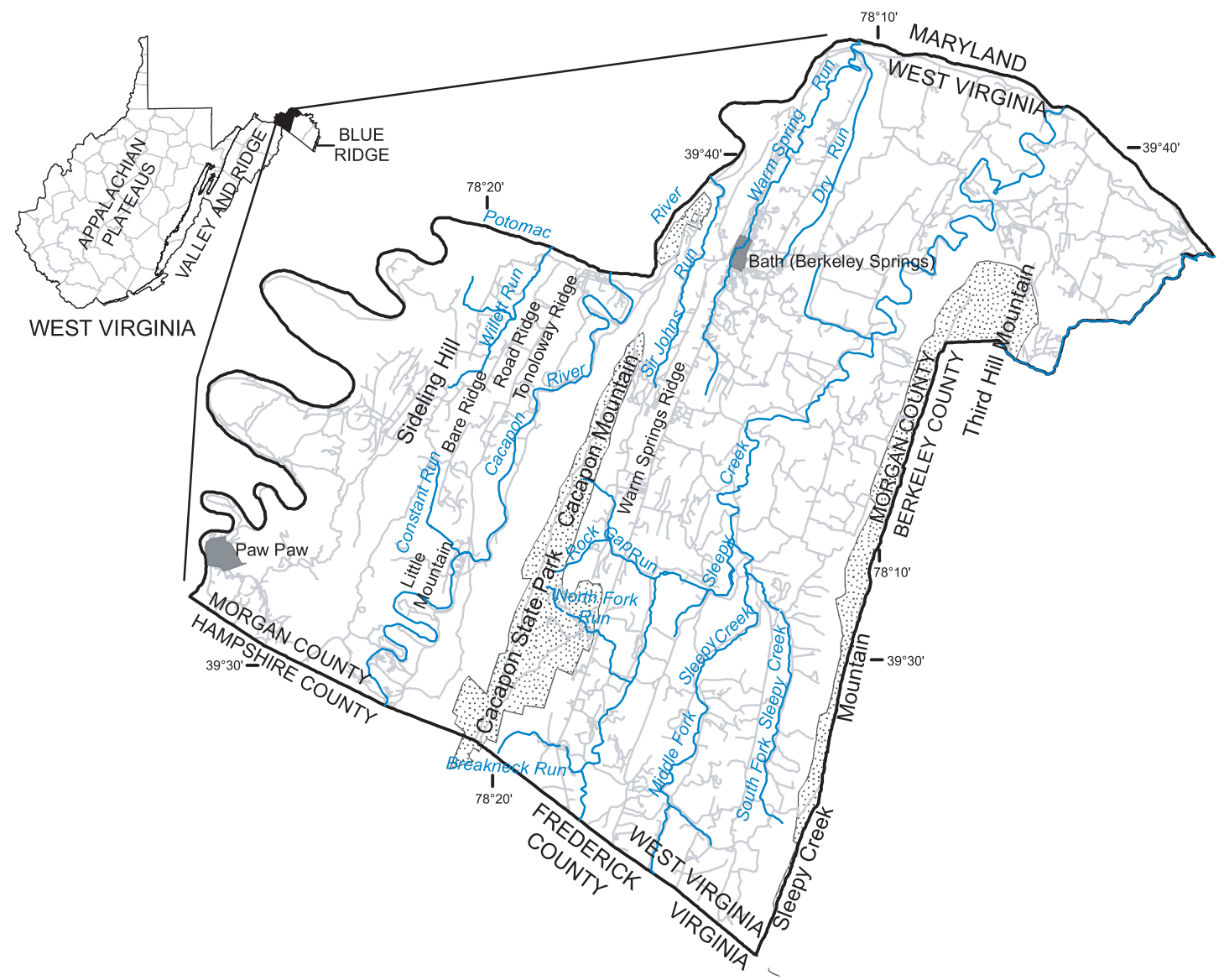

Scientific Investigations Report 2006-5198 



\section{Hydrogeology, Aquifer Geochemistry, and Ground-Water Quality in Morgan County, West Virginia}

By Carol J. Boughton and Kurt J. McCoy

Prepared in cooperation with the West Virginia Conservation Agency and the Eastern Panhandle Conservation District

Scientific Investigations Report 2006-5198 


\title{
U.S. Department of the Interior \\ DIRK KEMPTHORNE, Secretary
}

\section{U.S. Geological Survey \\ P. Patrick Leahy, Acting Director}

U.S. Geological Survey, Reston, Virginia: 2006

\author{
For product and ordering information: \\ World Wide Web: http://www.usgs.gov/pubprod \\ Telephone: 1-888-ASK-USGS
}

For more information on the USGS - the Federal source for science about the Earth, its natural and living resources, natural hazards, and the environment:

World Wide Web: http://www.usgs.gov

Telephone: 1-888-ASK-USGS

\begin{abstract}
Any use of trade, product, or firm names is for descriptive purposes only and does not imply endorsement by the U.S. Government.

Although this report is in the public domain, permission must be secured from the individual copyright owners to reproduce any copyrighted materials contained within this report.
\end{abstract}

Suggested citation:

Boughton, C.J., and McCoy, K.J., 2006, Hydrogeology, aquifer geochemistry, and ground-water quality in Morgan County, West Virginia: U.S. Geological Survey Scientific Investigations Report 2006-5198, 56 p. 


\section{Contents}

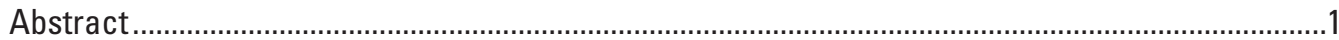

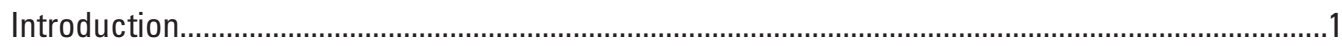

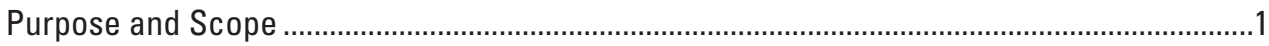

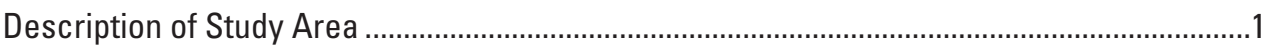

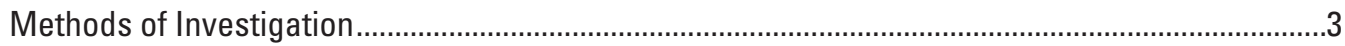

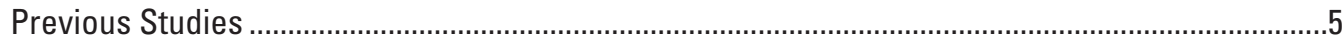

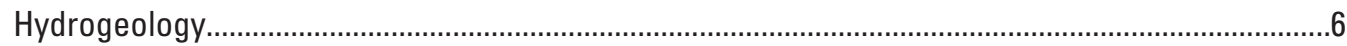

Geology

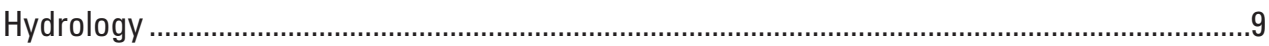

Relation of Geology to Ground-Water Flow.................................................................

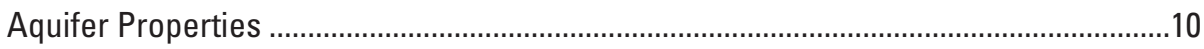

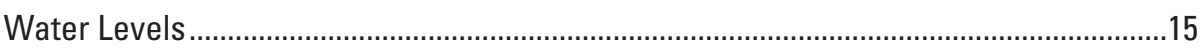

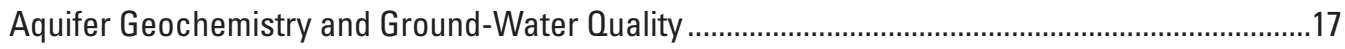

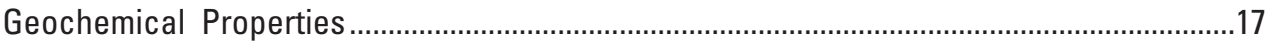

Water-Quality Characteristics .............................................................................................

$\mathrm{pH}$

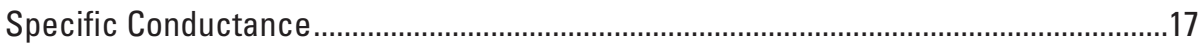

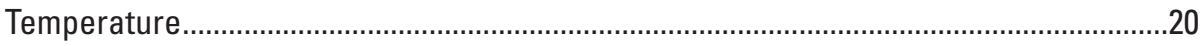

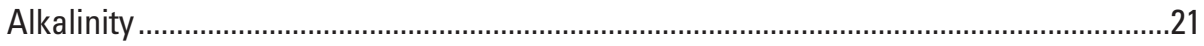

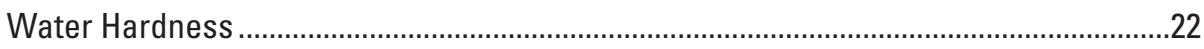

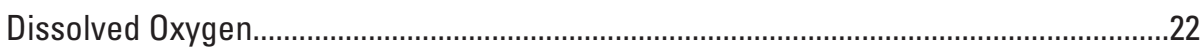

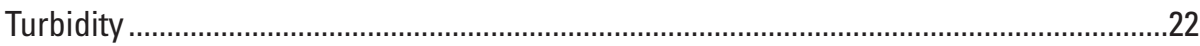

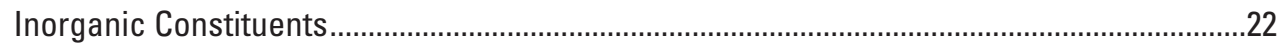

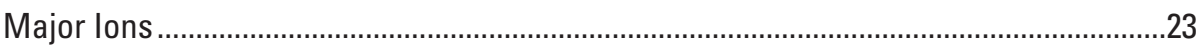

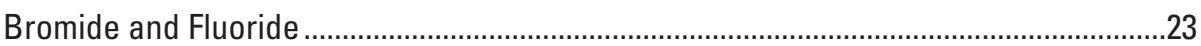

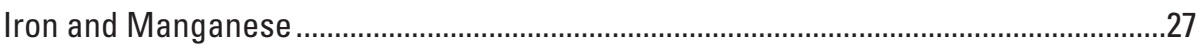

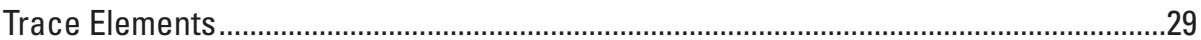

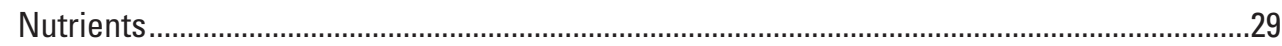

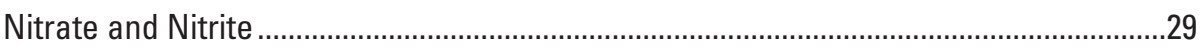

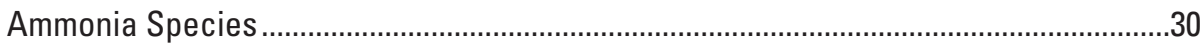

Phosphorous and Orthophosphate ...............................................................................

Radon-222

Bacteria

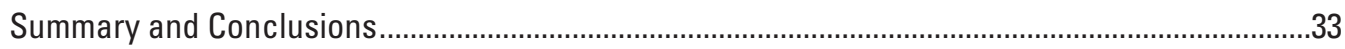

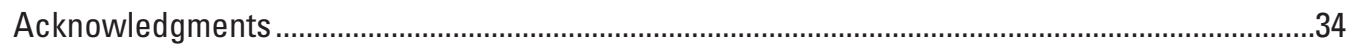

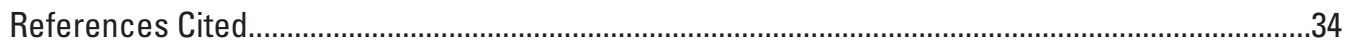

Appendix 1. Well-construction and aquifer properties for selected wells, Morgan County,

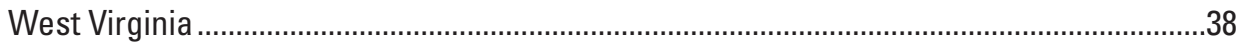

Appendix 2a-d. Water-quality data values for wells, Morgan County, West Virginia....................41

Appendix 3a-c. Water-quality data values for springs, Morgan County, West Virginia................54 


\section{Figures}

1.-3. Maps showing:

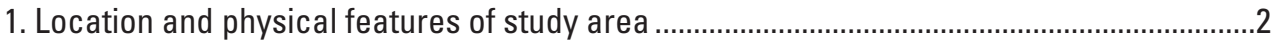

2. Location of wells and springs sampled in Morgan County, West Virginia .............................4

3. Geology of Morgan County, West Virginia, including major structural features and

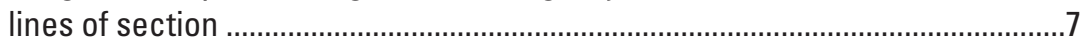

4. Generalized geologic section of the Great Cacapon and Paw Paw quadrangles,

Morgan County, West Virginia.........................................................................................8

5. Generalized geologic section of Stotlers Crossroads quadrangle, Morgan County,

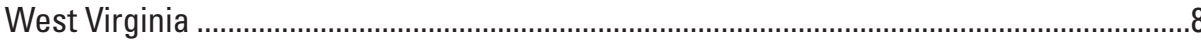

6. Conceptual model of ground-water flow through a faulted and fractured anticlinal ridge bordered by a synclinal ridge .....................................................................................11

7. Block diagram showing possible circulation of flow to a warm spring located near the crest of an anticline at the intersection of two faults....................................................11

8. Map showing locations and magnitudes of transmissivities, Morgan County,

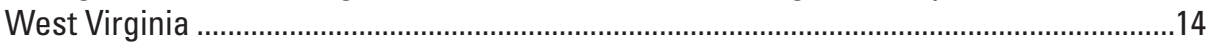

9. Map showing ground-water-level altitudes and depth to static water levels in Morgan County, West Virginia....................................................................................16

10.-15. Boxplots showing:

10. Distribution of $\mathrm{pH}$ values in ground-water samples from hydrogeologic units located in Morgan County, West Virginia ...................................................18

11. Relation between concentration of $\mathrm{pH}$ and alkalinity in ground-water samples from Morgan County, West Virginia ...........................................................18

12. Relation between concentration of $\mathrm{pH}$ and dissolved silica in ground-water samples from Morgan County, West Virginia..

13. Distribution of specific conductance in ground-water samples from hydrogeologic units located in Morgan County, West Virginia.

14. Distribution of temperature in ground-water samples from springs and wells located in Morgan County, West Virginia ......................................................20

15. Distribution of temperature in ground-water samples from hydrogeologic units located in Morgan County, West Virginia ......................................................21

16. Diagrams showing relative geochemical composition of ground water from springs and wells, by hydrogeologic unit, Morgan County, West Virginia....................................24

17.-22. Boxplots showing:

17. Distribution of concentrations of iron in ground-water samples from hydrogeologic units located in Morgan County, West Virginia.

18. Distribution of concentrations of manganese in ground-water samples from hydrogeologic units located in Morgan County, West Virginia...

19. Relation between concentrations of iron and manganese in ground-water samples from Morgan County, West Virginia...............................................................28

20. Relation between concentrations of zinc and aluminum in ground-water samples from Morgan County, West Virginia.

21. Distribution of concentration of radon-222 in ground-water samples from hydrogeologic units located in Morgan County, West Virginia......................31

22. Relation between the ratio of casing length to well depth and the occurrence of bacteria in wells located in Morgan County, West Virginia 


\section{Table}

1. Comparison of historical transmissivity and specific-capacity data (Kozar and Mathes, 2001)

with results from this study for geologic units occurring in Morgan County,

West Virginia

\section{Conversion Factors, Datum, and Abbreviations}

\begin{tabular}{|c|c|c|}
\hline Multiply & By & To obtain \\
\hline \multicolumn{3}{|c|}{ Length } \\
\hline inch (in.) & 25.4 & millimeter (mm) \\
\hline foot $(\mathrm{ft})$ & 0.3048 & meter $(\mathrm{m})$ \\
\hline mile (mi) & 1.609 & kilometer (km) \\
\hline \multicolumn{3}{|c|}{ Area } \\
\hline square mile $\left(\mathrm{mi}^{2}\right)$ & 2.590 & square kilometer $\left(\mathrm{km}^{2}\right)$ \\
\hline \multicolumn{3}{|c|}{ Flow rate } \\
\hline gallon per minute (gal/min) & 0.06309 & liter per second $(\mathrm{L} / \mathrm{s})$ \\
\hline inch per year (in/yr) & 25.4 & millimeter per year $(\mathrm{mm} / \mathrm{yr})$ \\
\hline \multicolumn{3}{|c|}{ Radioactivity } \\
\hline picocurie per liter (pCi/L) & 0.037 & becquerel per liter $(\mathrm{Bq} / \mathrm{L})$ \\
\hline \multicolumn{3}{|c|}{ Specific capacity } \\
\hline $\begin{array}{l}\text { gallon per minute per foot } \\
[(\mathrm{gal} / \mathrm{min}) / \mathrm{ft})]\end{array}$ & 0.2070 & liter per second per meter $[(\mathrm{L} / \mathrm{s}) / \mathrm{m}]$ \\
\hline \multicolumn{3}{|c|}{ Transmissivity } \\
\hline foot squared per day $\left(\mathrm{ft}^{2} / \mathrm{d}\right)$ & 0.09290 & meter squared per day $\left(\mathrm{m}^{2} / \mathrm{d}\right)$ \\
\hline
\end{tabular}

Temperature in degrees Celsius $\left({ }^{\circ} \mathrm{C}\right)$ may be converted to degrees Fahrenheit $\left({ }^{\circ} \mathrm{F}\right)$ as follows:

$$
{ }^{\circ} \mathrm{F}=\left(1.8 \times{ }^{\circ} \mathrm{C}\right)+32
$$

Vertical coordinate information is referenced to the National Geodetic Vertical Datum of 1929 (NGVD 29).

Horizontal coordinate information is referenced to the North American Datum of 1983 (NAD 83).

Altitude, as used in this report, refers to distance above the vertical datum.

Transmissivity: The standard unit for transmissivity is cubic foot per day per square foot times foot of aquifer thickness $\left[\left(\mathrm{ft}^{3} / \mathrm{d}\right) / \mathrm{ft}^{2}\right] \mathrm{ft}$. In this report, the mathematically reduced form, foot squared per day $\left(\mathrm{ft}^{2} / \mathrm{d}\right)$, is used for convenience.

Specific conductance is given in microsiemens per centimeter at 25 degrees Celsius $\left(\mu \mathrm{S} / \mathrm{cm}\right.$ at $\left.25^{\circ} \mathrm{C}\right)$.

Concentrations of chemical constituents in water are given either in milligrams per liter (mg/L) or micrograms per liter $(\mu \mathrm{g} / \mathrm{L})$. 
This page intentionally blank. 


\title{
Hydrogeology, Aquifer Geochemistry, and Ground-Water Quality in Morgan County, West Virginia
}

\author{
By Carol J. Boughton and Kurt J. McCoy
}

\section{Abstract}

Private and public wells throughout Morgan County, W. Va., were tested to determine aquifer hydraulic, geochemical, and water-quality characteristics. The entire study area is located in the Valley and Ridge Physiographic Province, a region of complex geologic structure and lithology. Aquifers in the study area are characterized by thin to thick bedded formations with interbedding among the various limestones, shales, sandstones, and siltstones that are folded into a series of steeply dipping north-south trending anticlines and synclines. Zones of ground-water production typically consist of one to two fracture sets, with little to no production from unfractured bedrock matrix. Measurements of transmissivity range from 2 to 1,490 feet squared per day, with the larger transmissivities occurring near bedding contacts and in zones with cross-faulting or jointing. Ground water flows from recharge areas in the uplands to local drainages and to deeper flow systems that appear to be controlled by regional geologic structure. The overall flow direction is from south to north within the study area.

Ground water within the study area is predominantly a calcium-bicarbonate type water reflecting contact with carbonate rocks. Sodium-bicarbonate and calcium-magnesium-sulfate end-members also exist, with many samples exhibiting mixing, which may be the result of flow between the differing rock types or within units containing both carbonate rocks and shales. Values of water-quality characteristics that were greater than U.S. Environmental Protection Agency drinking-water standards included radon-222, $\mathrm{pH}$, turbidity, iron, manganese, aluminum, and total- and fecal-coliform and Escherichia coli (E. coli) bacteria. Concentrations of radon-222 were detected in all samples from all units, with the largest concentrations (1,330 and 2,170 picocuries per liter) from the Clinton Formation.

\section{Introduction}

Economic expansion and population growth from the Baltimore, Md., and Washington, D.C., metropolitan corridor to Morgan County has led to increased construction of homes and businesses with commensurate demands on available ground-water supplies. Additional sources of good-quality water are needed to allow for continued population and economic growth and to provide alternative supplies in the event of a drought such as that during 2001-02. The U.S. Geological Survey (USGS), in cooperation with the West Virginia Conservation Agency and the Eastern Panhandle Conservation District, conducted a study to assess ground-water conditions to provide technical data that could be used as a basis for management of Morgan County water resources and future planning. Additionally, USGS assessed water-quality and geochemical characteristics of springs in cooperation with West Virginia University.

\section{Purpose and Scope}

This report describes hydrogeologic, geochemical, and water-quality characteristics of aquifers and geochemical and water-quality characteristics of select springs located in Morgan County, W. Va. The aquifer characteristics include the hydrogeologic, physical, and geochemical setting that may affect the observed quality. Geochemical, water-quality, and hydraulic data were collected over a 1-year period beginning in the spring of 2004 through the spring of 2005.

\section{Description of Study Area}

Morgan County occupies approximately $231 \mathrm{mi}^{2}$ in the eastern panhandle of West Virginia (fig. 1). The county was formed in 1820 from parts of Hampshire and Berkeley Counties and was named in honor of General Daniel Morgan, a prominent soldier of the Revolution (Holmes, 1995). The Potomac River forms the county's western and northern boundaries. Hampshire County, W. Va., and Frederick County, Va., form the southwestern and southeastern boundaries, respectively. Berkeley County, W. Va., bounds Morgan County to the east.

Morgan County lies in the Valley and Ridge Physiographic Province as defined by Fenneman (1946) and is characterized by a series of north-northeast trending anticlines and synclines, which form prominent valleys and ridges. The major physiographic features of much of Morgan County are steep-sloped mountains alternating with narrow valleys. 


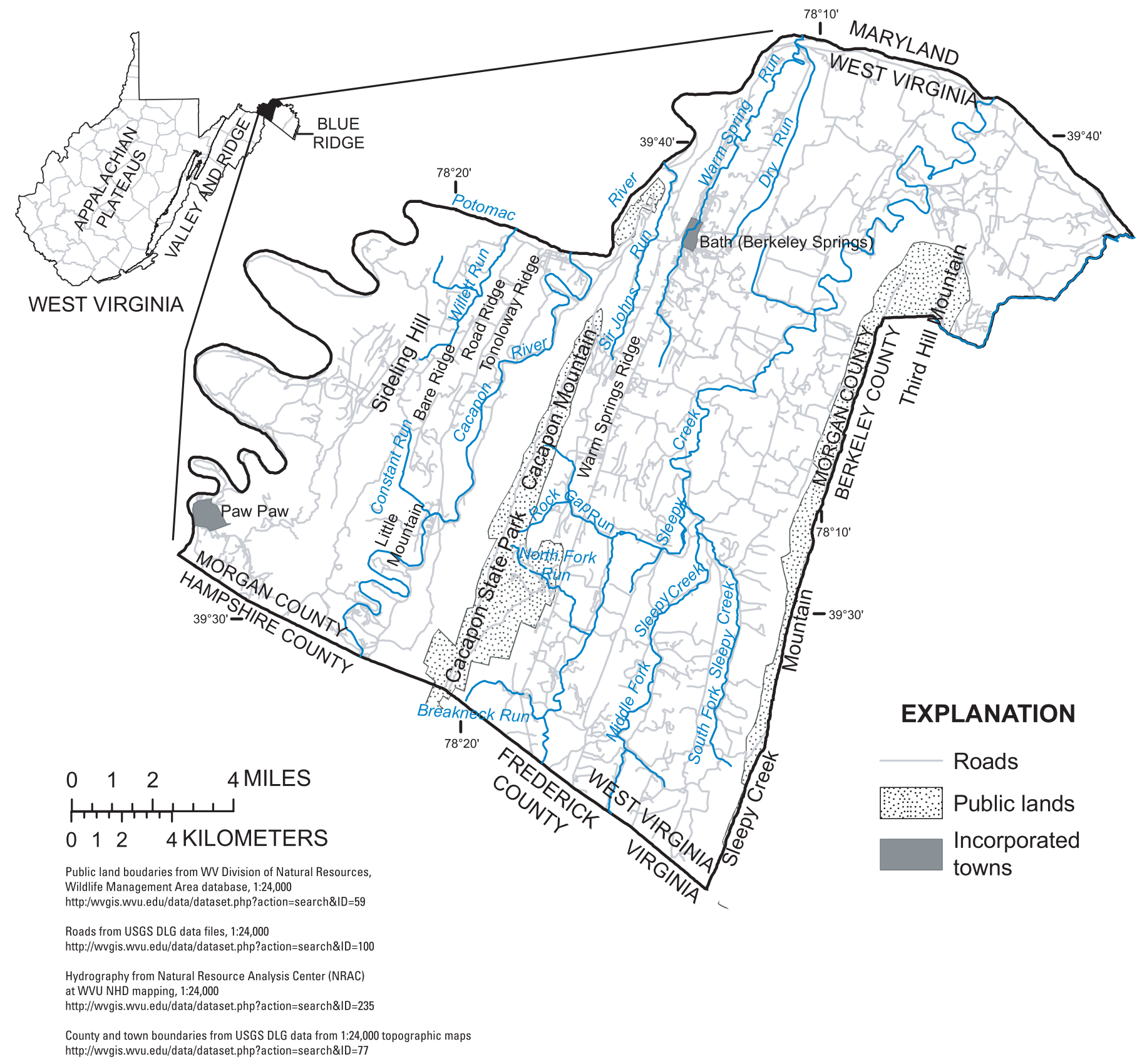

Figure 1. Location and physical features of study area. 
The exception is the eastern part of the county, which is characterized by rolling terrain transitioning to the Great Valley along the Route 9 corridor.

The climate of Morgan County is affected both by prevailing continental storm tracks from the west and maritime effects from the Atlantic Ocean (Doll and others, 1963). Precipitation in Morgan County falls as winter snow and as spring, summer, and fall rains. Weakened hurricanes can produce considerable rain during the late summer and early fall as the storm tracks flow northeastward along the Allegheny front. The mean annual precipitation as measured at Cacapon State Park is approximately $39 \mathrm{in} / \mathrm{yr}$ (National Oceanic and Atmospheric Administration, 2002) and ranges from approximately $36 \mathrm{in} / \mathrm{yr}$ in the valleys to $44 \mathrm{in} / \mathrm{yr}$ along the Sleepy Creek Mountain divide (Hobba and others, 1972).

In addition to the Potomac River, the Cacapon River and Sleepy Creek are two relatively large perennial streams within the county. Both streams flow in a northerly direction and drain into the Potomac River. The Sleepy Creek watershed is entirely within the county.

Smaller streams include Warm Springs Run, Breakneck Run, and Dry Run. The Potomac River bounds Morgan County on the west and north. All other streams tend to flow in a northerly direction parallel to major geologic structural controls and discharge into the Potomac River. Tributaries tend to follow trellis geomorphic patterns within structurally controlled basins. Sir Johns Run and Rock Gap Run are among exceptions that flow through interbasin water gaps controlled by lineaments (Lessing and others, 1991).

Historically, land use in Morgan County has been that of the rural landscape. Grimsley (1916) reported that Morgan County was one of the important peach and apple orchard sections of the state, exporting large quantities of those fruits. Additionally, the county had up to 25 canneries, mostly for tomatoes, another significant agricultural product (Grimsley, 1916). Two incorporated towns existed in 1910, Berkeley Springs (Bath) and Paw Paw, having populations of 864 and 725 , respectively (Grimsley, 1916). The leading industry was sand and glass, derived from the relatively pure, silica-rich Oriskany Sandstone that occurs in the county (Ice, 1933).

As reported in 1980, approximately 81 percent of land use in Morgan County was forest, 17 percent was agricultural land, and 1 percent was urban or built-up land (McColloch and Lessing, 1980). However, landscape and demographics within the county have changed appreciably during the past 20 years. In 1980, the Morgan County population was 10,606 (U.S. Department of Commerce, 1991). According to the 2000 census, the population had increased to 14,943 , an approximate 40 percent increase in 20 years. During 19902000 , the population increased by 23.2 percent
(U.S. Department of Commerce, 2005). Former agricultural and forested land is being urbanized to accommodate the increasing population.

\section{Methods of Investigation}

Well sampling sites were selected on the basis of (1) spatial distribution throughout the county and within representative geologic formations; (2) well age, in that wells that were recently completed were preferred, whenever possible; and (3) landowner's willingness to provide permission for access to existing wells.

Well-completion reports from the West Virginia Bureau for Public Health for 565 wells completed in Morgan County during 1997-2002 were reviewed for potential sampling-site suitability. The well-completion reports were evaluated for completeness and lithologic accuracy based upon knowledge of the geology within the county. Recently completed wells were preferred to ensure that the wells were properly grouted and sealed, thereby minimizing the potential for surface contamination along an open well bore (West Virginia Bureau for Public Health, 1984). After initial screening, less than one-half of the reports were considered to represent potentially appropriate well sites. Wells were excluded on the basis of incorrect lithologic descriptions and inadequate detail.

Potential wells were evaluated to provide spatial distribution throughout the county and among geologic formations. Most of the wells that were sampled were domestic wells used daily by the homeowners. Others were used seasonally or only for watering yards or for watering livestock, and some were public-supply wells.

Hydrogeologic units were sampled in an east-west cross section through the county with most aquifers having representative sites to the northern and the southern limits of the county to maximize areal distribution of sampling sites. Researchers at West Virginia University selected the spring sites for sampling. The USGS sampled these in cooperation with the university researchers who did a detailed assessment of springs in the study area. The resulting ground-water sampling network of 91 wells and 8 springs provides information about the variability of hydrogeologic characteristics, groundwater quality, and aquifer geochemistry within and among the water-bearing units (fig. 2).

Ground water was sampled using the techniques described in Wilde and others (1999) by purging each well with its existing pump. Springs were sampled with a pump as close to the point of emergence as possible. Measurements of $\mathrm{pH}$, specific conductance (SC), dissolved oxygen (DO), water temperature, and turbidity in water from the pumping well or spring were recorded until stability criteria were met. 


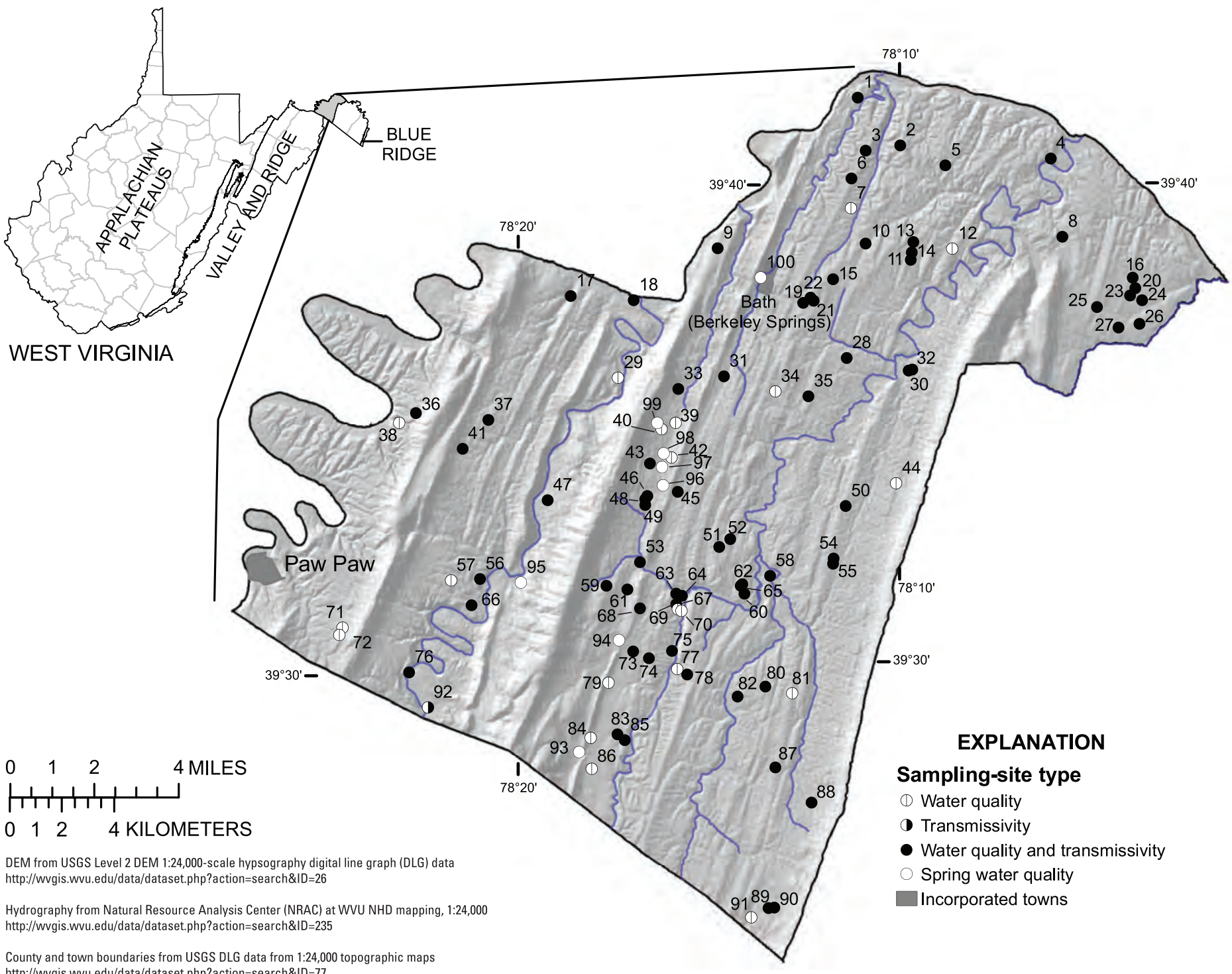

Figure 2. Location of wells and springs sampled in Morgan County, West Virginia. 
Then samples were collected and preserved in the field. Samples were shipped to the USGS National Water Quality Laboratory (NWQL) in Lakewood, Colo., where they were analyzed for concentrations of calcium, magnesium, sodium, potassium, chloride, sulfate, fluoride, iron, manganese, silica, total dissolved solids, hardness, and nutrients (nitrogen and phosphorous species) (American Public Health Association, 1998; Fishman, 1993; Fishman and Friedman, 1989; Patton and Truitt, 1992). Subsets of ground-water samples were analyzed for the trace elements bromide, barium, arsenic, aluminum, zinc, strontium, cadmium, lead, antimony, and nickel (Faires, 1993; Fishman and Friedman, 1989; Garbarino, 1999; Garbarino and Struzeski, 1998) and for the naturally occurring radioactive gas radon-222 (American National Standards Institute, 2004).

Carbonate alkalinity, bicarbonate alkalinity, and total alkalinity were measured in the field using the techniques described in Wilde and Radtke (1998). Total-coliform, fecalcoliform, and Escherichia coli (E. coli) bacteria were plated on site, incubated, and counted using techniques described in Myers and Wilde (2003).

\section{Previous Studies}

A detailed, systematic assessment of ground-water conditions throughout Morgan County has not been published previously. Grimsley (1916) provided an account of the historical and industrial development, the physiography, and the geology of the eastern panhandle counties, including Morgan County. The warm springs now known as Berkeley Springs in the town of Bath, W. Va., were prized by native Americans before the arrival of white settlers and George Washington noted them in his journal as early as 1747. According to Grimsley's account (1916), the springs were known for their uniform water temperature from 21 to $23^{\circ} \mathrm{C}$ throughout the year. Erskine (1948) documented seasonal temperatures and discharge from Berkeley Spring, Ziler Spring, and Breakneck Run Springs in his discussion of the principal springs in West Virginia.

Hoffman (1962) anticipated that the water needs of individual states, including West Virginia, might parallel the future national trend. He further suggested that West Virginia needed a close appraisal of its water resources and water problems due, in part, to its proximity to the eastern seaboard. According to Doll and others (1963), inadequate hydrologic data for planning purposes and increasing competition for water were among the water problems facing West Virginia.

Morgan County has been included in several regional studies. Doll and others (1963) described the water resources of the Potomac River Basin in West Virginia. Three wells in Morgan County, one from the Oriskany Sandstone and two from the Chemung Group, were identified as yielding $50 \mathrm{gal} / \mathrm{min}$ or more. They noted that artesian conditions occur in the deep-lying sandstone beds, reducing the amount of lift required but not necessarily producing large well yields. The largest reported concentration of total iron from shale aquifers was $10.0 \mathrm{mg} / \mathrm{L}$ and from limestone aquifers was $5.0 \mathrm{mg} / \mathrm{L}$. Water from shale aquifers tended to be more acidic than that from limestone aquifers. Within the Potomac River Basin, water from shallow, karstic limestone aquifers tended to have larger concentrations of nitrate and chloride at some locations. The one sample from Morgan County had much smaller concentrations of nitrate and chloride than other sites discussed (Doll and others, 1963).

Hobba and others (1972) published a compendium of water-resources information for the Potomac River Basin. Sandstone and carbonate-rock aquifers within the basin were characterized as having the largest supplies available, owing to fractures and solution cavities. Throughout the Potomac River Basin, carbonate aquifer yields are highly variable, from 5 to over $500 \mathrm{gal} / \mathrm{min}$, and depend upon the well depth and local geologic structure. The Oriskany Sandstone yields were variable depending upon whether the unit is well jointed, cemented, or friable. Low water tables may occur beneath ridges underlain by permeable zones of the Oriskany Sandstone as ground-water drains from the unit. In Morgan County, only one well, near Paw Paw, W. Va., was identified as producing from alluvium. Ground-water quality throughout the Potomac River Basin was found to be variable because of the complexity of the lithology and structure (Hobba and others, 1972).

Schwietering (1981) expanded on the work of Hobba and others (1972), describing ground-water conditions and aquifers on a statewide scale for West Virginia. Geohydrologic units were described in detail; however, few data were published specific to Morgan County except for a further discussion of Berkeley Springs.

Hobba (1985) describes ground-water quantity and quality in Hardy, Hampshire, and western Morgan Counties. These limited published data illustrate wide ranges in hydrogeologic and water-quality characteristics for sites in Morgan County.

Ferrell (1987) and Mathes and others (1998) provide summaries of available ground-water quality data, and Kozar and Mathes (2001) provide a compendium of aquifer characteristics throughout West Virginia. However, few data were available for Morgan County in these studies.

Cooper and Hanna (1988) compiled instantaneous discharge and temperature data for surface-water stations throughout West Virginia for 1945-75. Cacapon River near Great Cacapon, W. Va., was the only site located in Morgan County for which data were available.

Hobba and others (1979) discussed the geology, hydrology, and geochemistry of the Berkeley Springs area in their study of thermal springs in the Appalachians. McColloch (1986) produced a compendium of springs of West Virginia that summarizes available data for 14 springs in Morgan County, including Hancock Station Spring, Michael Farm Spring, Berkeley Springs, Robert Milborn Spring, Fahren Spring, Mitchum Farm Spring, Coolfont Spring, Whisner Farm Spring, Neely Farm Spring, Ziler Spring, Cacapon State 
Hydrogeology, Aquifer Geochemistry, and Ground-Water Quality in Morgan County, West Virginia

Park Spring, Ridge Hatchery Spring, O.B. Overmale Springs, and an unnamed spring.

\section{Hydrogeology}

Ground water is stored in intergranular spaces, in bedrock fracture features, and in solutionally enhanced fractures within Morgan County. The intergranular space within the bedrock matrix is referred to as primary porosity. Ground water does not flow readily through the intergranular spaces in bedrock because of a lack of connectivity and of cementation of voids. Ground water flows more readily through bedrock with secondary porosity. Secondary porosity occurs in fracture features, including faults, joints, and partings at contact zones and in solutionally enhanced features, which have much larger effective porosity. The structural and depositional geology controls the directional orientation and size of the fractures.

\section{Geology}

The rocks of Morgan County (fig. 3) are of Ordovician (Oswego and Juniata Formations), Silurian (Tuscarora Sandstone, Clinton Group, McKenzie Formation, Williamsport Sandstone, Wills Creek Formation, Tonoloway Formation), Devonian (Helderberg Group, Oriskany Sandstone, Onesquethaw Group, Marcellus Formation, Mahantango Formation, Harrell Shale, Brallier Formation, Chemung Group, and Hampshire Formation), and Mississipian (Pocono Group), ages (Cardwell and others, 1968). The rocks were folded and faulted extensively during the formation of the Appalachian Mountains, resulting in a series of northeast-southwest trending anticlines and synclines with beds of varying width (figs. 4 and 5). The beds plunge slightly to the north. Underlying resistant rocks such as sandstones form the ridges and less resistant rocks such as shales typically form the valleys (Hobba and others, 1972).

Lithologic descriptions in well-completion reports and other available mapping are approximate on a site-specific basis; therefore, throughout this report, undifferentiated references to the Brallier Formation will include the Brallier Formation and the Harrell Shale and references to the Tonoloway Formation will include the Tonoloway Formation, Wills Creek Formation, and Williamsport Sandstone. The Needmore Shale and Huntersville Chert are mapped as the Onesquethaw Group (Cardwell and others, 1968), but the section is so narrow in the study area that it is not mappable at the 1:250,000 scale.

Deposits of unconsolidated alluvial material typically occur near major streams and consist primarily of clay and silt, with some discontinuous lenses of sand and gravel. Alluvial deposits occasionally occur on terraces, but are typically unsaturated. Significant saturated thicknesses are generally found only near major streams (Hobba and others, 1972). No wells were identified as producing from the alluvium in this study; therefore, the alluvial aquifer system is not discussed further in this report.

The Pocono Group is gray, hard, massive sandstone with some shale beds. The thickness of the Pocono Group is as much as 1,030 ft (Cardwell and others, 1968). It is underlain by the Hampshire Formation, a maroon to reddish-brown siltstone and shale in the upper 300 to $400 \mathrm{ft}$ of the formation and fine-grained, well-cemented, hard, massive red sandstone with some shale in the lower part. The thickness of the Hampshire Formation is as much as 3,350 ft (Cardwell and others, 1968). The Chemung Group is typically a rusty-yellowish brown. The upper formation is thin-bedded, hard, blocky sandstone underlain principally by thin-bedded siltstone and shale. The thickness of the Chemung Group is as much as $2,115 \mathrm{ft}$ (Cardwell and others, 1968). A massive sandstone member occurs at its base in the easternmost areas (Hobba and others, 1972). The Pocono Group, Hampshire Formation, and Chemung Group occur extensively in both the western and eastern parts of the county.

The Brallier Formation is a greenish-gray shale with siltstone and sandstone that constitutes approximately 35 percent of the formation. The thickness of the Brallier Formation is as much as $1,300 \mathrm{ft}$ (Cardwell and others, 1968). The Harrell Shale is black shale that occurs in the lower 50 to $400 \mathrm{ft}$ of this formation. The thickness of the Harrell Shale is zero to $50 \mathrm{ft}$ (Cardwell and others, 1968). Lying below the Harrell Shale, the Mahantango Formation consists of brown sandy shales with occasional sandstone beds and concretions found near the contact with the underlying Marcellus Formation. The thickness of the Mahantango Formation is as much as 1,200 ft (Cardwell and others, 1968). The Marcellus Formation is black carbonaceous, clayey, thinly laminated, fissile shale containing pyrite and minor amounts of siltstone (Reger, 1924). The thickness of the Marcellus Formation is as much as $200 \mathrm{ft}$ (Cardwell and others, 1968). Thinly bedded and 20 to $40 \mathrm{ft}$ thick, the Purcell Member of Pennsylvanian limestone (Cardwell and others, 1968) occurs approximately 50 to $150 \mathrm{ft}$ from the base (Reger, 1924), and large limestone concretions are known to occur near the base of the Marcellus Formation (Hobba and others, 1972).

The Onesquethaw Group, consisting of the Needmore Shale and Huntersville Chert, occurs below the Marcellus Formation. The Needmore Shale is a predominately dark gray or green, calcitic, mostly nonfissile, gamma-ray-emitting shale. It includes the Black Beaver Dam Shale member and grades westward into the Huntersville Chert. The Tioga bentonite occurs near the top of the Needmore Shale. The thickness of the Needmore Shale ranges from $75 \mathrm{ft}$ to $140 \mathrm{ft}$ (Cardwell and others, 1968). 


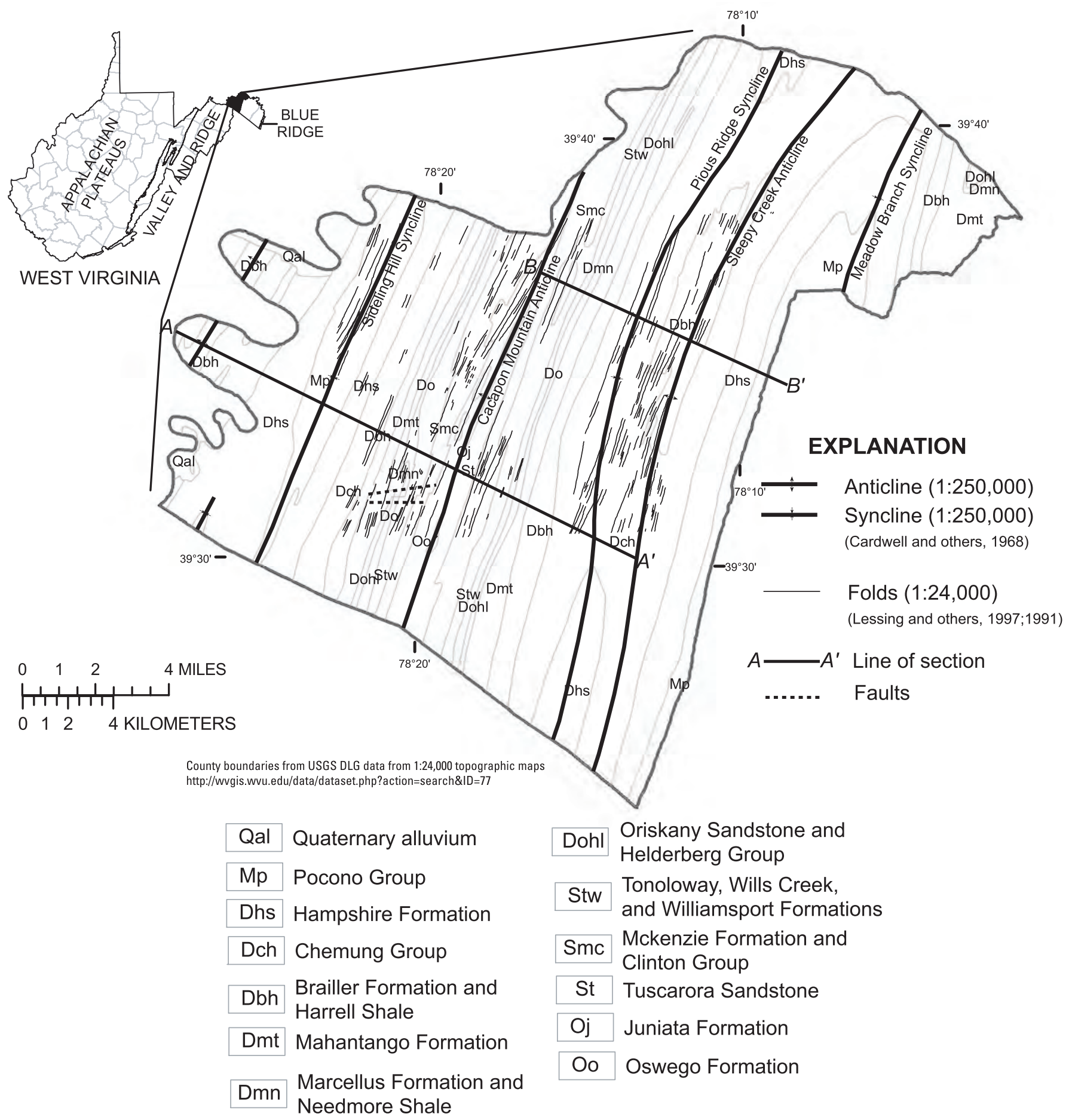

Figure 3. Geology of Morgan County, West Virginia, including major structural features and lines of section. Geology modified from Lessing and others (1997), Lessing and others (1991), and Cardwell (1968). 


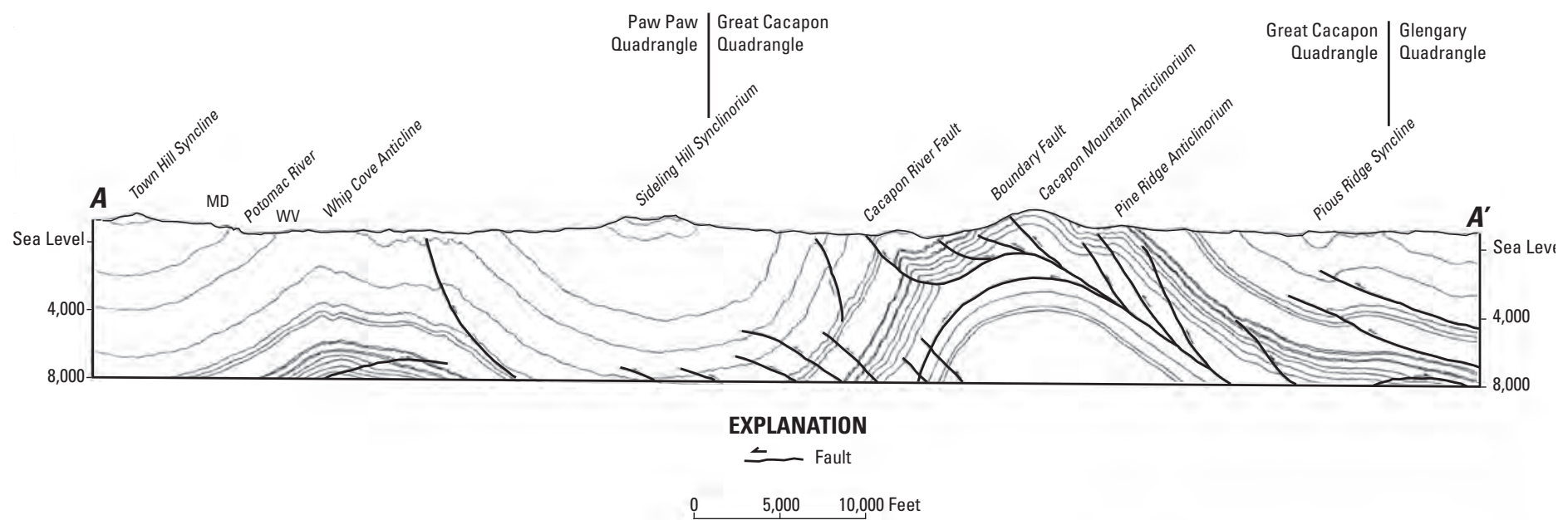

Figure 4. Generalized geologic section of the Great Cacapon and Paw Paw quadrangles, Morgan County, West Virginia. Modified from Lessing and others (1997). (Line section of $A-A^{\prime}$ as shown on figure 3.)

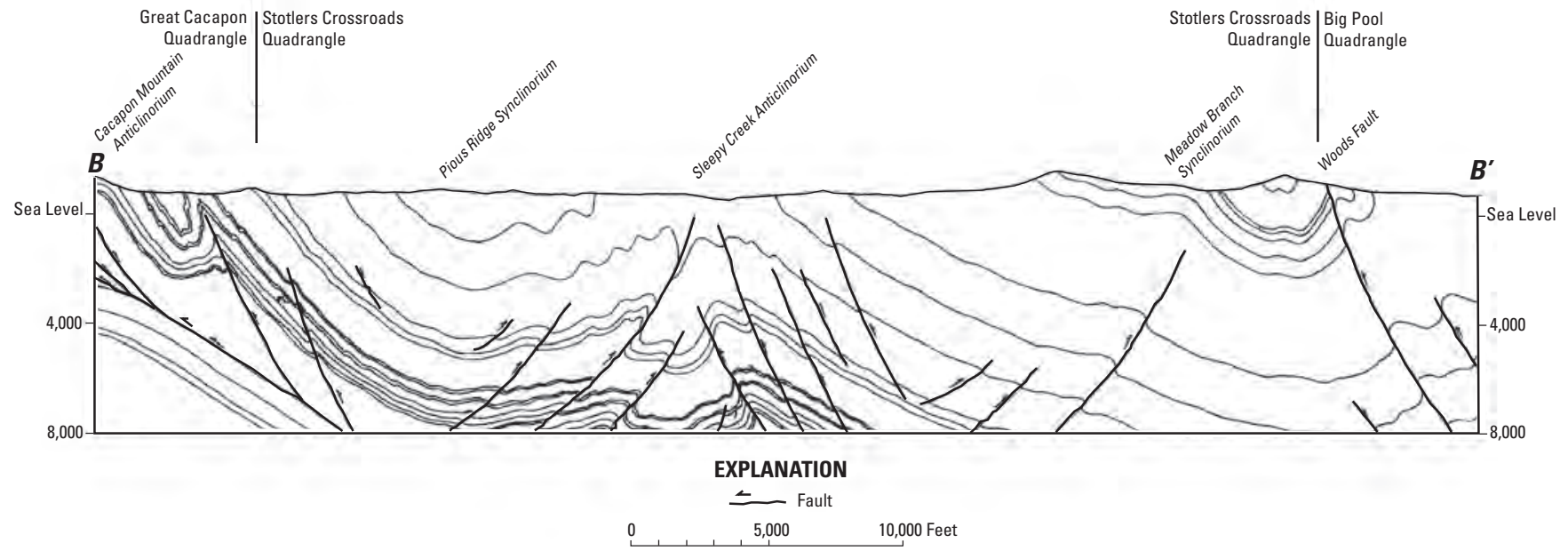

Figure 5. Generalized geologic section of Stotlers Crossroads quadrangle, Morgan County, West Virginia. Modified from Kulander and others (1995). (Line of section $B-B^{\prime}$ as shown on figure 3.) 
The other member of the Onesquethaw Group is the Huntersville Chert, which grades from a nearly pure, slightly calcitic or dolomitic chert (interbedded with the Needmore Shale), to a limestone westward. That limestone, commonly referred to as the Onondaga, includes the glauconitic $[(\mathrm{K}, \mathrm{Na})($ $\left.\mathrm{Fe}^{3+}, \mathrm{Al}, \mathrm{Mg}\right)_{2}(\mathrm{Si}, \mathrm{Al})_{4} \mathrm{O}_{10}(\mathrm{OH})_{2}$ ] Bobs Ridge Sandstone member (Cardwell and others, 1968). Although the Onesquethaw (Onondaga) Group is narrow and may not constitute a potentially significant aquifer, its mineralogy may affect groundwater quality where it does occur. The gamma-ray emissions may be associated with radon in drinking water. Glauconite is used as a water softener, so its occurrence could account for zones of naturally occurring soft water.

The Oriskany Sandstone is a medium- to thick-bedded brown to white sandstone lying between two layers of soft calcareous chert. The thickness of the Oriskany Sandstone ranges from $12 \mathrm{ft}$ to $275 \mathrm{ft}$ (Cardwell and others, 1968). Cementation of these rocks varies from very hard silica cement to softer carbonate cement to friable and devoid of cement depending upon the location. The upper chert layer ranges in thickness from 0 to $100 \mathrm{ft}$. In Morgan County, the lower Shriver Chert is very thin or absent (Hobba and others, 1972).

The Helderberg Group varies from thin-bedded, light-colored, cherty limestone in the upper part to thin-bedded shale in the middle part to massive-bedded relatively pure limestone in the lower part. The thickness of the Helderberg Group is as much as $170 \mathrm{ft}$ (Cardwell and others, 1968). The underlying Tonoloway Formation consists of gray, flaggy, thin beds containing some silica and dolomite and grading downward into flaggy limestone and calcareous shales of the Wills Creek Shale. Red or green sandy shales and one hard sandstone bed occur at the base (Hobba and others, 1972). The thickness of the Tonoloway Formation is as much as $590 \mathrm{ft}$ and the thickness of the Wills Creek Shale is as much as $400 \mathrm{ft}$ (Cardwell and others, 1968).

The McKenzie Formation is a bluish-gray, wavy-bedded, flaggy limestone and limy shale, whereas the underlying Clinton Group consists of red shale with thin beds of sandstone and occasional limestone layers. The thickness of the McKenzie Formation is as much as $240 \mathrm{ft}$ (Cardwell and others, 1968). The Tuscarora Sandstone is thick-bedded, extremely hard, resistant, and is colored gray to pink. By way of contrast, the "red beds" of the Juniata Formation are thinbedded block sandstone and shale. In places, this formation is underlain by thick-bedded gray Oswego Sandstone (Hobba and others, 1972). The thickness of the Tuscarora Sandstone is as much as $100 \mathrm{ft}$; of the Juniata Formation is as much as $320 \mathrm{ft}$; and of the Oswego Sandstone is as much as $300 \mathrm{ft}$ (Cardwell and others, 1968).

\section{Hydrology}

The study area is predominantly underlain by folded, faulted, and fractured sedimentary shale, carbonate, and sandstone rocks that form the aquifer systems. Recharge occurs throughout the study area, particularly in the upland areas. Discharge occurs locally to streams and springs, then regionally to the Potomac River. Ground-water discharge, including spring discharge, provides base flow to the streams.

\section{Relation of Geology to Ground-Water Flow}

The flow of ground water in the study area is complicated because of the structural and lithologic complexity of the Valley and Ridge Physiographic Province. The bedrock generally has small primary permeability in the rock matrix and much larger secondary permeability in fractures, along bedrock contacts, and in solutionally enhanced zones of preferential flow. Similar to the hydrogeology of the Appalachian Plateaus Physiographic Province (Wyrick and Borchers, 1981), wells that do not penetrate fractures or solution channels will not produce usable amounts of water. Flow paths in Morgan County are complicated by the complex system of steeply dipping, northsouth trending anticlines and synclines that form the topography typical of the Valley and Ridge Physiographic Province.

Well yields in primarily limestone rock along the axes of anticlines are found to be appreciably larger than those along axes of synclines (Clark and others, 1976). Siddiqui and Parizek (1972) found that variation in structural control is not a statistically significant factor in the productivity of wells not located on fracture traces. Ground-water flow in Morgan County may occur through fracture sets that parallel anticlinal axes. Where deep vertical faults or horizontal thrust faults intersect these fractures, they provide conduits for potentially large well yield.

McCoy and others (2005a, 2005b) found in Berkeley and Jefferson Counties that discrete fracture zones within the bedrock yield water to the majority of wells tested. Over 500 recent (1997-2004) well-completion reports for Morgan County were examined during the course of this study. Not all completion reports clearly indicated the water-production zones encountered. The completion reports that indicate location of production zones show a clear pattern of production from one to two discrete zones, sometimes described as being at contacts between units and sometimes as apparent fracture zones within a given bedrock unit. There was no indication of usable, continuous production along the well bore from either fractures or bedrock matrix. Although many fractures intersect a borehole, only a few may yield usable quantities of ground water. Aquifer yields are dependent upon water produced from fractures, faults, or along contact zones.

Ground water flows from areas with higher hydraulic head toward areas of lower hydraulic head. The preferential flow path followed will be that which has the largest transmissivity or ability to transmit water. Toth (1963) describes an idealized model for flow systems in most field areas with negligible local topographic relief; however, in areas with pronounced local relief, such as the Valley and Ridge Province, it is possible that only local systems develop (Freeze and Cherry, 1979). 
Within the study area, the ground water flows from recharge areas in the uplifted geologic features such as Cacapon Mountain and Sleepy Creek Mountain toward the valleys and then discharges to the north toward the Potomac River. Locally, ground water flows to springs, streams, or nearby pumping wells that intercept the flow and cause minor, localized perturbations in the flow path.

Transmissivity, typically, is the largest downdip along bedding planes or fractures parallel to bedding planes, although intersecting faults or fracture zones may act as drains and route flow across structural features. The folded and uplifted bedrock of the Appalachian Mountains may serve as a barrier to flow between major tributary basins such as the Cacapon and Warm Springs Run watersheds except where flow occurs along bedding planes or through other fractured and faulted features (fig. 6).

Cross-faulting occurs near the town of Bath, where the Berkeley Springs arise (Hobba and others, 1979). Ground water contributing to the Berkeley Springs is thought to be derived from recharge to and deep flow through the Oriskany Sandstone. Water budget, temperature, and geochemical data tend to support this conceptual model (Hobba and others, 1979). Water is recharged rapidly into and through the friable Oriskany Sandstone and the cross-faulting serves as a drain, routing water to the Berkeley Springs (fig. 7).

Other structural offsets occur in addition to the fault trace depicted above. Structural offsets also occur at Rock Gap Run, North Fork Run, and Breakneck Run, which dissect Warm Springs Ridge and at Constant Run (Ziler Ford), which dissects Tonoloway Ridge at its southern edge. Cardwell and others (1968) mapped joints (approximately perpendicular to faults) coincident with the Constant Run, Rock Gap Run, and North Fork Run drainages. In addition to the Berkeley Springs, other regional springs occur in the study area.

Lessing and others (1991) report the relations between eight warm springs and the geology of eastern West Virginia by use of side-looking airborne-radar (SLAR). All of the springs discharge from Oriskany Sandstone or adjacent limestones of the Helderberg Group, although deep ground-water circulation to the Helderberg Group may be through the Oriskany Sandstone. They hypothesize that precipitation recharges the Oriskany Sandstone at ridgetop outcrops, then percolates deeply through the friable Oriskany Sandstone along fault zones where the ground water is geothermally heated. The ground water then flows through the highly permeable lineament, surfacing at the spring sites rapidly enough that the heat is not dissipated.

Ridge Hatchery Spring (site 93) surfaces in Breakneck Run, and Cacapon Spring (site 94) occurs in North Fork Run. Bedrock in lower Breakneck Run is highly fractured and occurs as blocky rubble along the mountainside and onto the valley floor. Zones of blocky fractured bedrock and bedrock rubble are very transmissive to water. Shallow subsurface flow can be heard beneath the rubblized deposits along the val- ley floor in the Breakneck Run drainage. Recharge areas for the Ridge Hatchery Springs include Cacapon Mountain and potentially some local component of flow from Warm Springs Ridge. Ridge Hatchery Springs does not appear to have come from a deep flow system, as evidenced by water temperature and specific conductance.

\section{Aquifer Properties}

The specific capacity of a well is the rate of discharge of a well divided by the drawdown of the water level in the well and depends both upon the hydraulic properties of the aquifer and upon the construction and other features of the well. Specific-capacity estimates may be used to evaluate regional differences in transmissivity, which is the capability of an aquifer to transmit water through a unit width of aquifer under a unit hydraulic gradient (Heath, 1983). Short-term, single-well aquifer tests are used as the basis for estimating transmissivity of aquifer units in Morgan County. Transmissivity estimates are useful for developing a conceptual model of the aquifer and as input for modeling a ground-water flow system; however, transmissivity can be highly variable from one geographic location to another, both within a given geologic unit and among units. Additionally, an aquifer with a large transmissivity may be vulnerable to rapid contaminant transport, and aquifers with large transmissivities may be locally depleted if stressed beyond their sustainable yield.

Kozar and Mathes (2001) compiled aquifer characteristics from existing sources for the entire State of West Virginia. Two key characteristics discussed in that publication are specific capacity, defined as the rate of discharge of a well divided by the drawdown of the water level in the well; and transmissivity, defined as the rate at which water of a prevailing viscosity is transmitted through a unit width of aquifer under a unit hydraulic gradient (Kozar and Mathes, 2001). Although few of the data originated from wells in Morgan County, the values provide insight as to the range of values for hydraulic properties that occur throughout the extent of the hydrogeologic units. Specific-capacity and tranmissivity data from throughout West Virginia (Kozar and Mathes, 2001) are summarized in table 1 for hydrogeologic units that occur in the study area. Except where otherwise noted, no data from the Kozar and Mathes (2001) report are available for the study area.

The largest specific capacity $(600(\mathrm{gal} / \mathrm{min}) / \mathrm{ft})$ and transmissivity $\left(60,000 \mathrm{ft}^{2} / \mathrm{d}\right)$ are in the Helderberg Group, Tonoloway Formation, and Wills Creek Shale. The Pocono Group and related MacCrady Formation, Hampshire Formation, and Chemung Group have the potential for moderate yields with maximum specific capacities of $8.67(\mathrm{gal} / \mathrm{min}) / \mathrm{ft}$, $12.5(\mathrm{gal} / \mathrm{min}) / \mathrm{ft}$, and $30.7(\mathrm{gal} / \mathrm{min}) / \mathrm{ft}$, respectively, and maximum transmissivities of $2,300 \mathrm{ft}^{2} / \mathrm{d}, 2,900 \mathrm{ft}^{2} / \mathrm{d}$, and $8,300 \mathrm{ft}^{2} / \mathrm{d}$, respectively. One site located in the study area has a specific capacity of $0.89(\mathrm{gal} / \mathrm{min}) / \mathrm{ft}$ and an estimated transmissivity of $240 \mathrm{ft}^{2} / \mathrm{d}$ from the Hampshire Formation (Kozar and Mathes, 2001). 


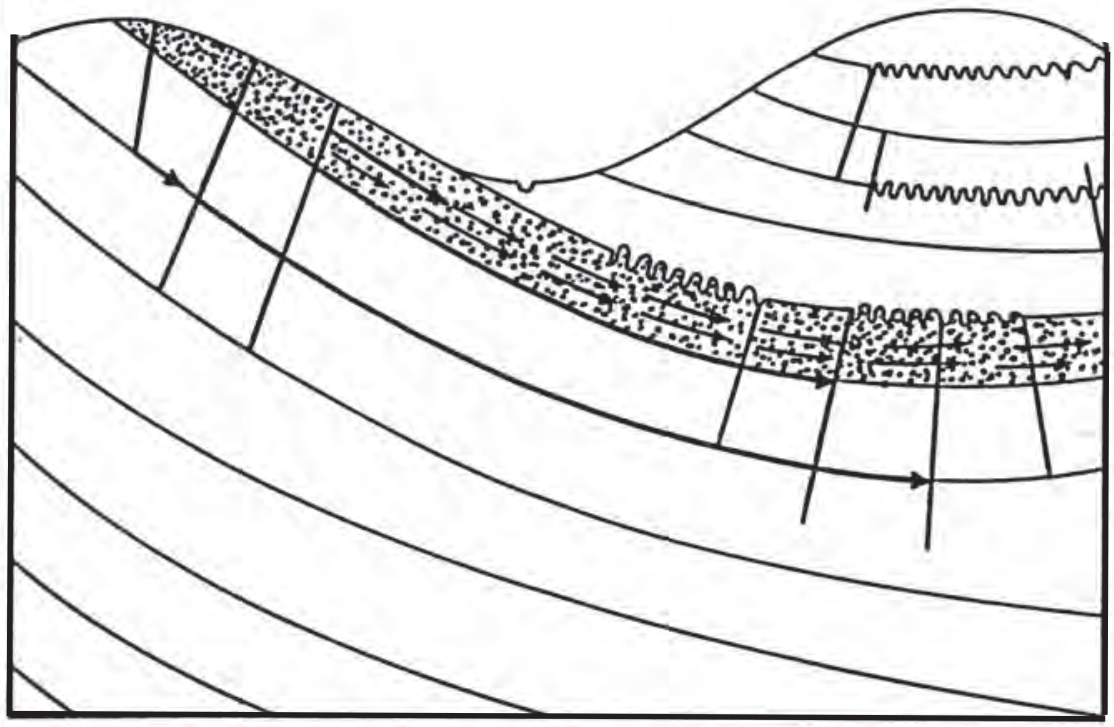

Figure 6. Conceptual model of ground-water flow through a faulted and fractured anticlinal ridge bordered by a synclinal ridge. Water infiltrates through faults and fractures along the anticlinal ridge, then flows parallel to the bedding plane to recharge a confined aquifer underlying the nearby syncline (modified from Hobba and others, 1979).

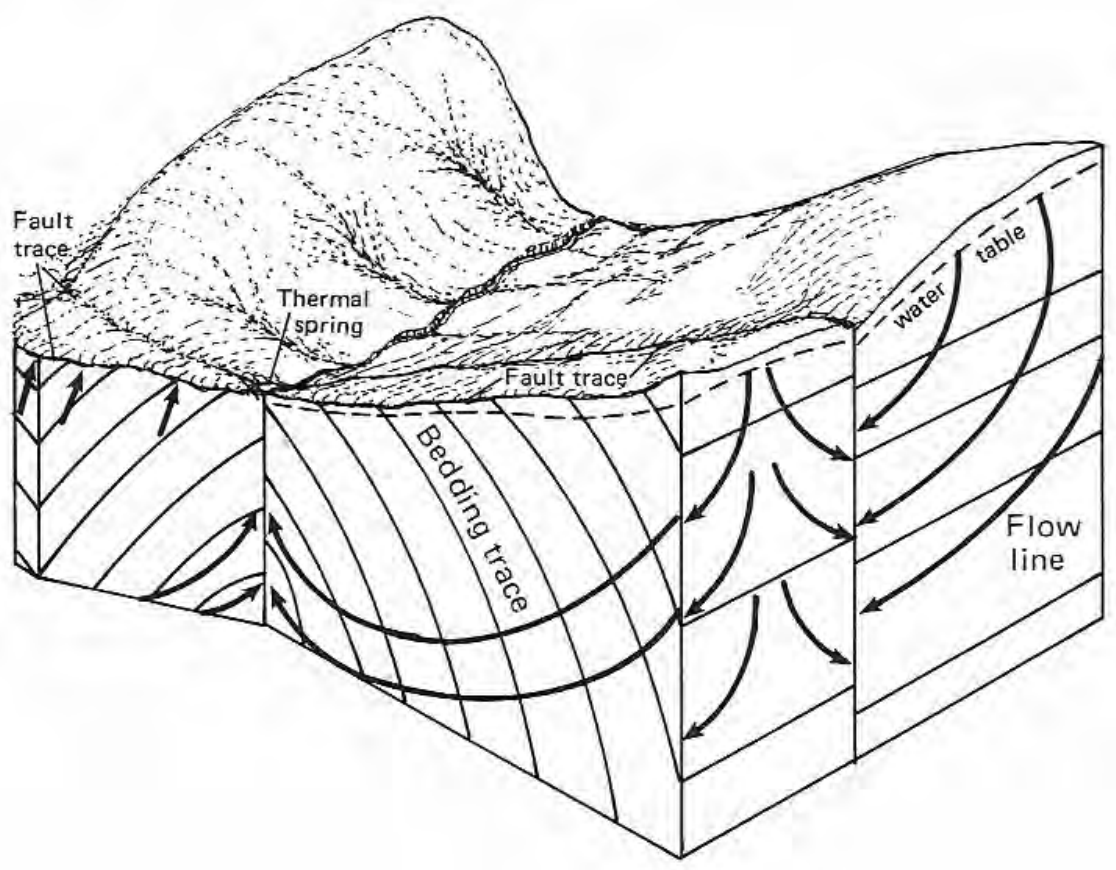

Figure 7. Block diagram showing possible circulation of flow to a warm spring located near the crest of an anticline at the intersection of two faults (modified from Hobba and others, 1979). 


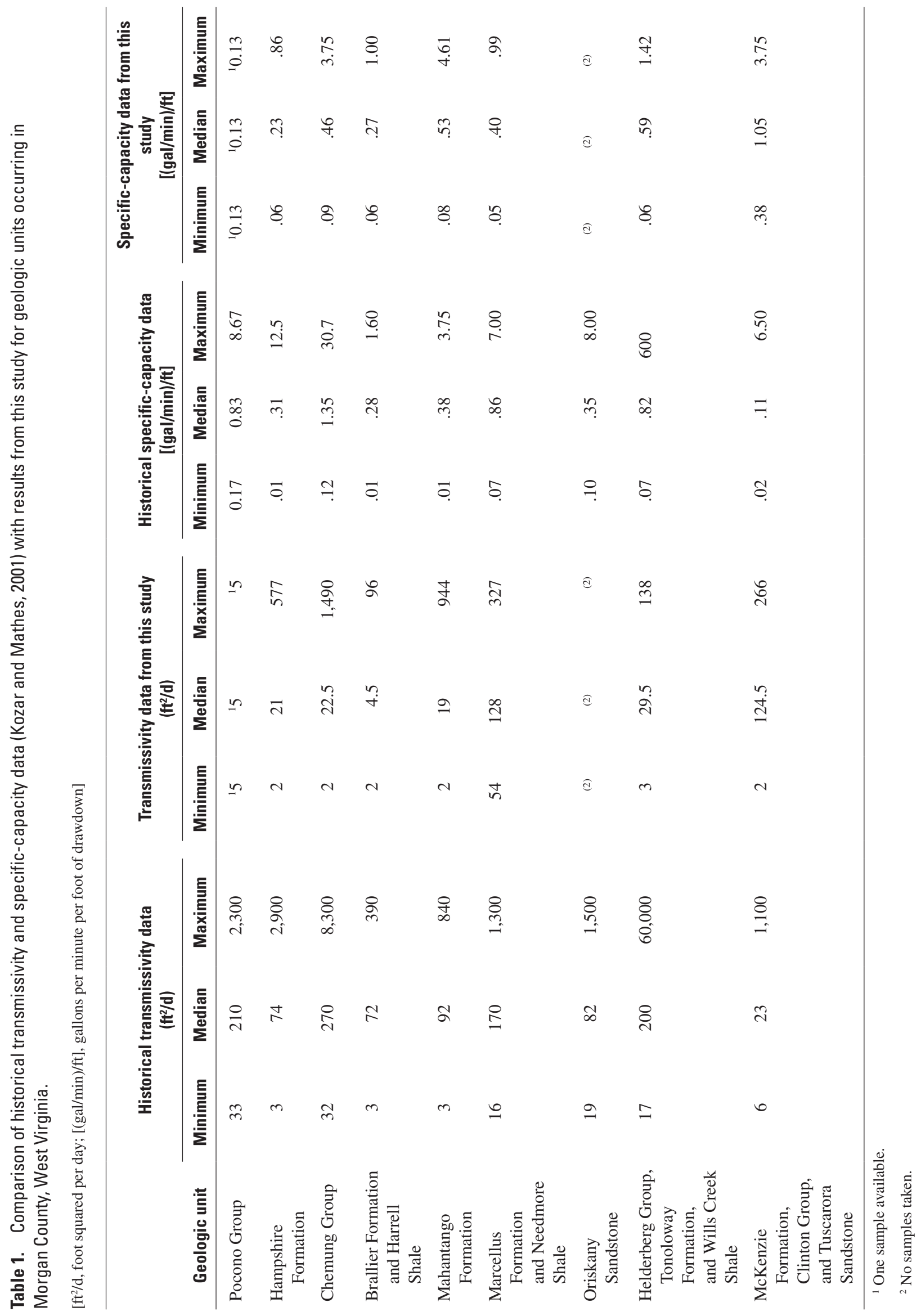


The Mahantango Formation; Marcellus Formation and Needmore Shale; Oriskany Sandstone; and McKenzie Formation, Clinton Group, and Tuscarora Sandstone generally have much smaller maximum specific capacities of $3.75(\mathrm{gal} / \mathrm{min}) / \mathrm{ft}$, $7.00(\mathrm{gal} / \mathrm{min}) / \mathrm{ft}, 8.00(\mathrm{gal} / \mathrm{min}) / \mathrm{ft}$, and $6.50(\mathrm{gal} / \mathrm{min}) / \mathrm{ft}$, respectively, and transmissivities of $840 \mathrm{ft}^{2} / \mathrm{d}, 1,300 \mathrm{ft}^{2} / \mathrm{d}$, $1,500 \mathrm{ft}^{2} / \mathrm{d}$, and 1,100 $\mathrm{ft}^{2} / \mathrm{d}$, respectively. The Brallier Formation and Harrell Shale have the smallest maximum specific capacity $(1.60(\mathrm{gal} / \mathrm{min}) / \mathrm{ft})$ and maximum transmissivity (390 $\mathrm{ft}^{2} / \mathrm{d}$ ) (Kozar and Mathes, 2001) (table 1).

Single-well aquifer tests were done on private and publicsupply wells to estimate transmissivity of aquifers in Morgan County (Appendix 1). Short-term aquifer tests, consisting of a drawdown phase and recovery phase, were done at most sites. In some instances, well production was so small and drawdown was so rapid that aquifer tests were discontinued prior to completion of the tests to avoid effects to the homeowner's well. In other instances, water levels were at a depth greater than $300 \mathrm{ft}$ and could not be measured with available equipment. Some wells contained spacers or other equipment that precluded downhole placement of the pressure transducer necessary to conduct the test. Pump-cycling (the pump turning on and off) occurred at many of the sites.

During the drawdown test, the wells were pumped for approximately 30 minutes at a flow rate ranging from 0.80 to $60.0 \mathrm{gal} / \mathrm{min}$. The analytical technique of Theis (1935) could not be used for tests in which interference occurred because of pump cycling. Transmissivity was computed only from recovery data at those sites.

When the pumping is terminated, water from within the aquifer flows toward the well bore and, over time, the water level recovers to static conditions. During this aquifer recovery period, water-level data typically were recorded for approximately 60 minutes, with some recorded for as long as 131 minutes. Recovery data were analyzed by using the techniques of Theis (1935), which are based upon certain simplifying assumptions of aquifer properties: a homogeneous (identical properties throughout), isotropic (same properties with the same values when measured along axes in all directions), confined aquifer that is uniform in thickness and infinite in extent. The well is assumed to be infinitesimally small in diameter and to fully penetrate a confined aquifer. These are considered ideal aquifer conditions. Conditions in Morgan County are nonideal conditions; however, the technique was applied to generate a range of values for the aquifer properties of hydrogeologic units in the study area.

With the exception of the highly friable zones of the Oriskany Sandstone, aquifers in Morgan County are very heterogeneous and anisotropic. Typically, well-completion reports for the county indicate the presence of only one to two isolated zones of production along the length of the wellbore. Parameter estimates in poorly transmissive zones of the aquifer are subject to error because of unaccounted-for wellbore storage effects.
Tiedeman and Hsieh (2001) tested fractured crystallinerock aquifers and concluded that the borehole connects highly permeable zones separated by impermeable rock. Hsieh and Shapiro (1996) further state that single-well tests show the effects of only the few highly transmissive fractures and are not representative of the overall bulk-rock properties. Schad and Teutsch (1994) suggest that the Theis solution can be used for comparison of values within a single dataset rather than representing the values as valid for a rock type. For the purposes of this report, the transmissivity values are used to evaluate the variability within aquifers and among rock types in Morgan County and should not be used for direct comparison with data from other areas, although they may provide a basis for design of more complex aquifer tests.

Parameter estimates from drawdown and recovery tests agreed to within 174 percent of each other. Parameter estimates from recovery tests exceeded those from drawdown tests at 74 percent of the sites. Reported values reflect the average transmissivity derived from both the pumping and recovery tests. The median transmissivity for the entire dataset (91 wells with 21 pumping and 70 recovery tests) was $23.0 \mathrm{ft}^{2} / \mathrm{d}$, with a minimum of $2.0 \mathrm{ft}^{2} / \mathrm{d}$ and a maximum of 1,490 $\mathrm{ft}^{2} / \mathrm{d}$ (Appendix 1).

Linear regression analysis of Morgan County well sites shows no significant correlation $\left(r^{2}=0.00\right)$ between well depth and transmissivity. The median transmissivity for wells with depths less than or equal to $150 \mathrm{ft}$ below land surface is $27.2 \mathrm{ft}^{2} / \mathrm{d}$. The median transmissivity for wells greater than $150 \mathrm{ft}$ below land surface is $21.4 \mathrm{ft}^{2} / \mathrm{d}$. This transmissivity distribution indicates that discrete flow zones, although smaller at depth, are not restricted to the upper portion of the aquifers. The data also are consistent with data from nearby Berkeley County, W. Va., that indicate a slight reduction in aquifer yield below a depth of approximately $150 \mathrm{ft}$ below land surface (Shultz and others, 1995). Transmissivities range over more than two orders of magnitude. The largest calculated transmissivities were at site 77, which lies approximately at the contact between the Chemung Group and the Brallier Formation with a transmissivity of $1,420 \mathrm{ft}^{2} / \mathrm{d}$, and at site 85 , which lies approximately at the contact between the Mahantango and Brallier Formations, with a transmissivity of $944 \mathrm{ft}^{2} / \mathrm{d}$ (fig. 8). In the study area, larger aquifer transmissivity typically occurs at or near geologic contacts and in zones of cross-faulting or thrust-faulting.

Transmissivity data for geologic units located in the study area from previous studies are compared with those from this study (table 1). In general, the transmissivities from this study were smaller than those previously documented for the Hampshire Formation, Chemung Group, and Brallier, Mahantango, Marcellus, Tonoloway, and Clinton Formations (Kozar and Mathes, 2001). Only one site was sampled in the Pocono Group, and that transmissivity was nearly an order of magnitude smaller than those reported by Kozar and Mathes (2001). 


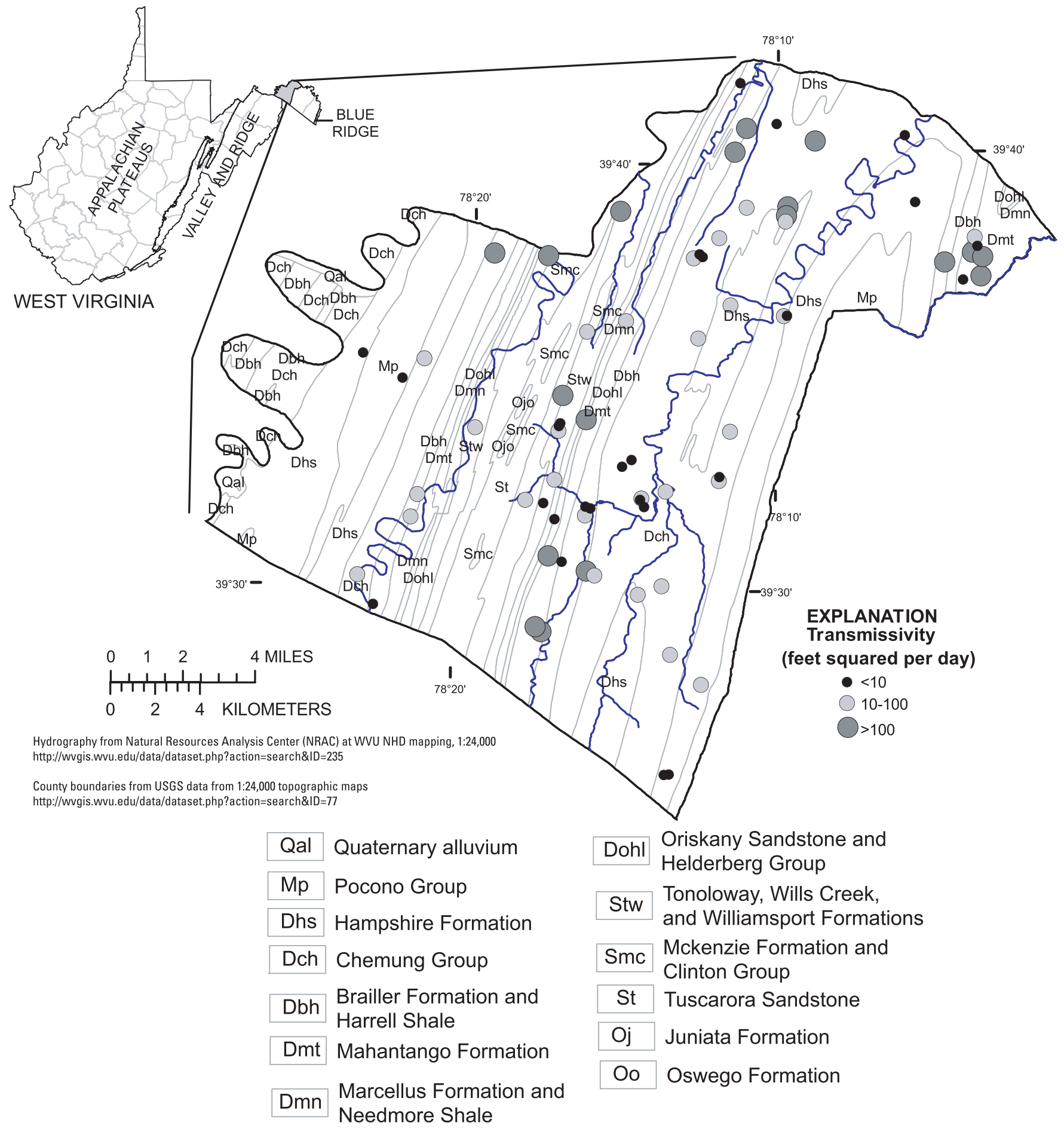

Figure 8. Locations and magnitudes of transmissivities, Morgan County, West Virginia. Geology after Cardwell (1968). 
Values for previous transmissivity data within the study area for the Marcellus and Hampshire Formations (Kozar and Mathes, 2001) are within the range of values obtained during this study. Site-specific hydrogeologic details are difficult to assess from the literature; however, depths for the sites with the largest transmissivities reported by Kozar and Mathes (2001) tend to be shallower than the typical well depth in Morgan County. Well yields decrease appreciably at depths below approximately $150 \mathrm{ft}$ below land surface because of a decrease in fracturing (Shultz and others, 1995). Lithostatic pressure from the mass of overlying rock tends to compress fracture partings. Tranmissivity of the Oriskany Sandstone was not sampled during this study because it has narrow outcrops along Warm Springs Ridge where few dwellings exist, thus limiting availability of sampling sites.

Site-specific geographic location cannot be used to predict transmissivity. Wells in close geographic proximity within the study area have transmissivities that vary by more than two orders of magnitude. The exception is that aquifers tested along ridgetops tend to have smaller transmissivities than those in valley settings, and zones of production tend to be deep, in excess of $400 \mathrm{ft}$ below land surface.

\section{Water Levels}

Ground-water flow paths are a reflection of the complex geologic setting in the study area. Static water-level data were obtained at 84 sites throughout Morgan County (fig. 9).

Data density is not adequate to predict local or site-specific flow systems with any certainty or to develop countywide static water-level contours. These data are used to develop a conceptual model of the generalized ground-water-flow patterns, which will be addressed progressively from west to east in the study area.

The Sideling Hill Syncline is a recharge area with recharge draining to depth through the fractured Hampshire Formation. Wells range from 380 to $460 \mathrm{ft}$ deep and have low yields from fracture sets at depth. Static water levels range from approximately $100 \mathrm{ft}$ to greater than $220 \mathrm{ft}$ below land surface. Bare Ridge, Road Ridge, and Tonoloway Ridge may form structural barriers to the east. Ground-water flow appears to be northward within the Willett Run drainage, as the static water level is several hundred feet lower at the north end of that drainage than at its southern reaches.

Water levels at locations near the Cacapon River range from $20 \mathrm{ft}$ to approximately $60 \mathrm{ft}$ below land surface. The ground-water gradient indicates that ground-water flow follows a path similar to the Cacapon River from the southern boundary of the study area, through a water gap at Constant Run that occurs at the south end of Tonoloway Ridge, and then northward. The Constant Run water gap is coincidental with cross-faulting that occurs in that gap between the south end of Tonoloway Ridge and the north end of Little Mountain (fig. 3). That fault trace appears to be present at the Potomac River to the west and is evident as far east as Cacapon Mountain.
It appears to act as a subsurface drain to the north-northeast, along the Cacapon River Fault. There may be a ground-water divide north of the fault trace, but additional data are required to validate that hypothesis.

Cacapon Mountain is a recharge area. The hinge line of the Cacapon Mountain Anticline may be a drainage divide with ground water flowing to the west and the east; however, the Boundary Fault underlies Cacapon Mountain. This slip-fault extends as deep as the Martinsburg Decollement, several thousand feet below land surface and may serve as a bounding fault to the west or the fault zone may serve as a conduit for deep flow to the ground-water system east of the anticline. Grimsley (1916) characterizes this area has having a series of crumpled, fluted folds mapped at the surface, which tends to support the potential for flow through fractures or joints. Alternatively, ground water could flow toward the west and may leave the system through the Cacapon River Fault zone (fig. 4). Deep flow to the east from the crest of Cacapon Mountain could account for head needed to produce the artesian conditions (water levels within 10 feet or less from land surface) that occur in Sir Johns Run and east of Warm Springs Ridge (sites 33, 34, 61, 70, 73, and 74) (fig. 2).

Hydrogeologic data are not available along the crest of Cacapon Mountain (the anticline hinge-line), but one site (59) near the top of the mountain has a static water level of approximately 1,080 ft above sea level, considerably higher than others in the Sir Johns Run drainage. Sir Johns Run drainage is described by Grimsley (1916) as a Silurian valley lying between the resistant sandstone ridge that caps Cacapon Mountain and Warm Springs Ridge also formed by another resistant sandstone unit, the Oriskany Sandstone. The drainage between was formed by erosion of intervening, less resistant shales. Ground-water level altitudes in Sir Johns Run drainage tend to be lower toward the north, from approximately $890 \mathrm{ft}$ to $710 \mathrm{ft}$ at the north end of the drainage, indicating that ground water flows northward. There is an anomaly in the water levels in Warm Springs Run drainage north of the town of Bath. This localized perturbation of the flow path may be the result of dewatering operations at a mine in Warm Springs Ridge.

The Third Hill Mountain complex lies along the hinge line of the Meadow Branch Synclinorium. Localized recharge occurs along this ridge, which also acts as a ground-water divide with flow to the northeast and northwest following the north-south structural trends with the units plunging slightly to the north. Water levels confirm this conceptual model. Six wells were hydraulically tested in the area east of Third Hill Mountain; the transmissivity measured at four of those wells was more than $100 \mathrm{ft}^{2} / \mathrm{d}$, whereas the transmissivity at two of the sites was appreciably less than $20 \mathrm{ft}^{2} / \mathrm{d}$. This variability may be complicated by the occurrence of the Woods thrust fault in that area that offsets already complex geology. Grimsley (1916) reported the presence of striated and polished rock surfaces, known as slickensides, on the faults near Third Hill Mountain. Slickenside rocks may act as barriers to flow rather than as conduits typical of extensively fractured rock. 


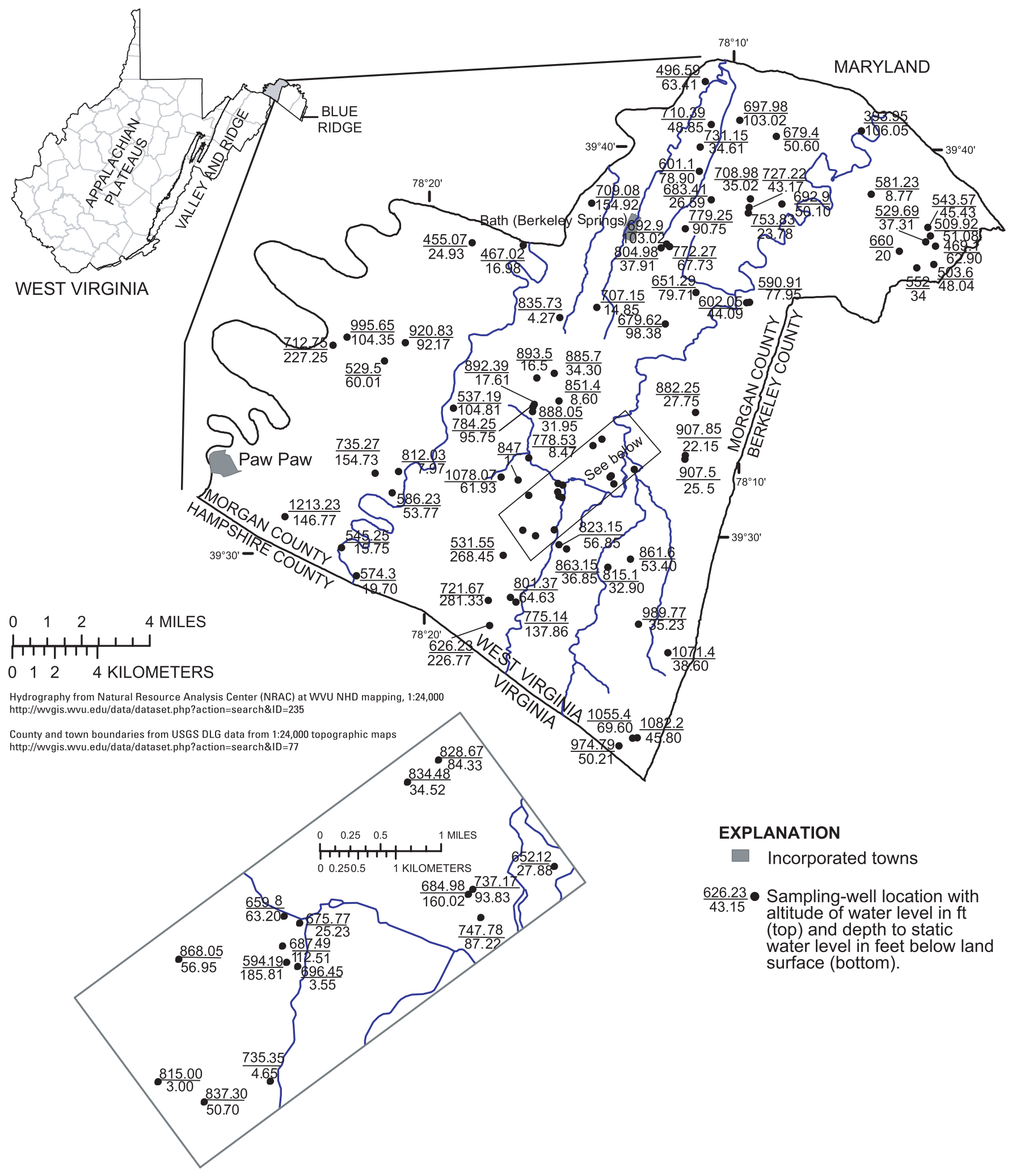

Figure 9. Ground-water-level altitudes and depth to static water levels in Morgan County, West Virginia. 


\section{Aquifer Geochemistry and Ground- Water Quality}

Ninety-one wells and eight springs in the study area were evaluated for aquifer geochemistry and ground-water-quality characteristics (Appendixes 2 and 3). Geochemical properties and ground-water quality are largely affected by composition of the rocks in the aquifer. Additionally, contaminants may be introduced by human activities or other environmental factors. USEPA has established regulatory water-quality standards for specified constituents for the point of delivery from public water supply systems. The standards are based upon potential human-health or esthetic effects (U.S. Environmental Protection Agency, 2005a, b, c).

\section{Geochemical Properties}

Geochemical properties of aquifer systems are naturally variable and dependent upon the mineralogic composition of the rocks encountered along the ground-water flow path. The three major sedimentary rock types (carbonates, sandstones, shales) all occur in Morgan County. Limestone and dolomite rocks have a predominant calcium-bicarbonate or calciummagnesium-bicarbonate geochemical signature, respectively. Pure sandstone is quartzite that may be cemented by silica or by calcium carbonate or may contain little cementation. In Morgan County, cementation of the Oriskany Sandstone varies depending upon location. Sandstone cemented by silica may have up to 99 percent pure silica content, which will be reflected in the geochemical signature. Shales primarily consist of various clay minerals and quartz. Shales formed under anaerobic conditions may retain organic matter and may have a large sulfur content. Other shales may be enriched in metals such as arsenic, barium, boron, chromium, copper, fluoride, gallium, lithium, mercury, selenium, titanium, uranium, yttrium, vanadium, and zinc (Brownlow, 1979). Ground water may reflect a mixture of the geochemical characteristics as it flows progressively through one rock unit and then through another. Complex geochemical interactions may result in dissolution of certain constituents and precipitation of other constituents over time. Geochemical properties and concentrations of water-quality constituents for wells and springs sampled during this study are presented in Appendixes 2 and 3 , respectively.

\section{Water-Quality Characteristics}

Where appropriate, concentrations or other water-quality values are compared with U.S. Environmental Protection Agency (USEPA) Maximum Contaminant Levels (MCLs) and Secondary Maximum Contaminant Levels (SMCLs) drinkingwater standards established for water at the point of delivery from public drinking-water supply systems. The MCLs are health-based drinking-water standards, whereas SMCLs are established on the basis of cosmetic effects such as skin or tooth discoloration, esthetic effects such as taste, odor, or color, and potential damage to plumbing systems such as corrosiveness (U.S. Environmental Protection Agency, 2005b and d). No water-quality standards are established for water from private wells or springs.

$\mathrm{pH}$

The USEPA SMCL states that $\mathrm{pH}$ should range from 6.5 to 8.5 (U.S. Environmental Protection Agency, 2005d). A $\mathrm{pH}$ of 7.0 indicates a neutral aqueous solution. $\mathrm{A} \mathrm{pH}$ higher than 7.0 is indicative of alkaline water, and a $\mathrm{pH}$ lower than 7.0 is indicative of acidic water. The corrosiveness of water to pipes and plumbing increases as the $\mathrm{pH}$ decreases. Excessive alkalinity in water also can attack metals. The $\mathrm{pH}$ of water at 32 sites was lower than $6.5 \mathrm{pH}$ units. No samples had $\mathrm{pH}$ in excess of $8.5 \mathrm{pH}$ units (fig. 10). The maximum $\mathrm{pH}$ measured at any of the sites was $7.7 \mathrm{pH}$ units. The median $\mathrm{pH}$ of samples from the Clinton Formation was 5.55 and from the Marcellus Formation was 5.75. The $\mathrm{pH}$ in all other units combined was 6.75. The $\mathrm{pH}$ of the Marcellus and Clinton Formations is appreciably more acidic than the other units, which tend to be more neutral.

Geochemically, $\mathrm{pH}$ is a significant control on the dissolution of certain naturally occurring metals. Alternatively, $\mathrm{pH}$ is controlled by the aquifer material. For instance, in oxidizing conditions, $\mathrm{pH}$ may be low because of dissolution of ferrous-containing minerals, whereas $\mathrm{pH}$ may rise because of hydrolysis of silicates resulting in a geochemical environment that is both alkaline and reducing (Garrels and Christ, 1965). In the study area, alkalinity increases at $\mathrm{pH}$ measurements greater than approximately 6 (fig. 11). Concentrations of silica increase appreciably at $\mathrm{pH}$ measurements greater than 6 (fig. 12).

\section{Specific Conductance}

Specific conductance is a measure of the ability of a substance to conduct an electrical current and is reported in units of microsiemens per centimeter at 25 degrees Celsius $(\mu \mathrm{S} / \mathrm{cm})$. Specific conductance of water increases as the concentrations of dissolved ions increase. More mineralization produces a higher specific conductance. Specific-conductance values from the Tonoloway Formation had the largest variability among the hydrogeologic units sampled, ranging from 318 to $737 \mu \mathrm{S} / \mathrm{cm}$, with a median value of $445 \mu \mathrm{S} / \mathrm{cm}$ and a standard deviation of $118.7 \mu \mathrm{S} / \mathrm{cm}$ (fig. 13). Specific-conductance values from the Brallier Formation had the least variability, ranging from 202 to $322 \mu \mathrm{S} / \mathrm{cm}$, with a median value of $270 \mu \mathrm{S} / \mathrm{cm}$ and a standard deviation of $35.5 \mu \mathrm{S} / \mathrm{cm}$. Samples from all other formations varied by up to an order of magnitude from the minimum to the maximum specific-conductance value. 
EXPLANATION

6 number of values
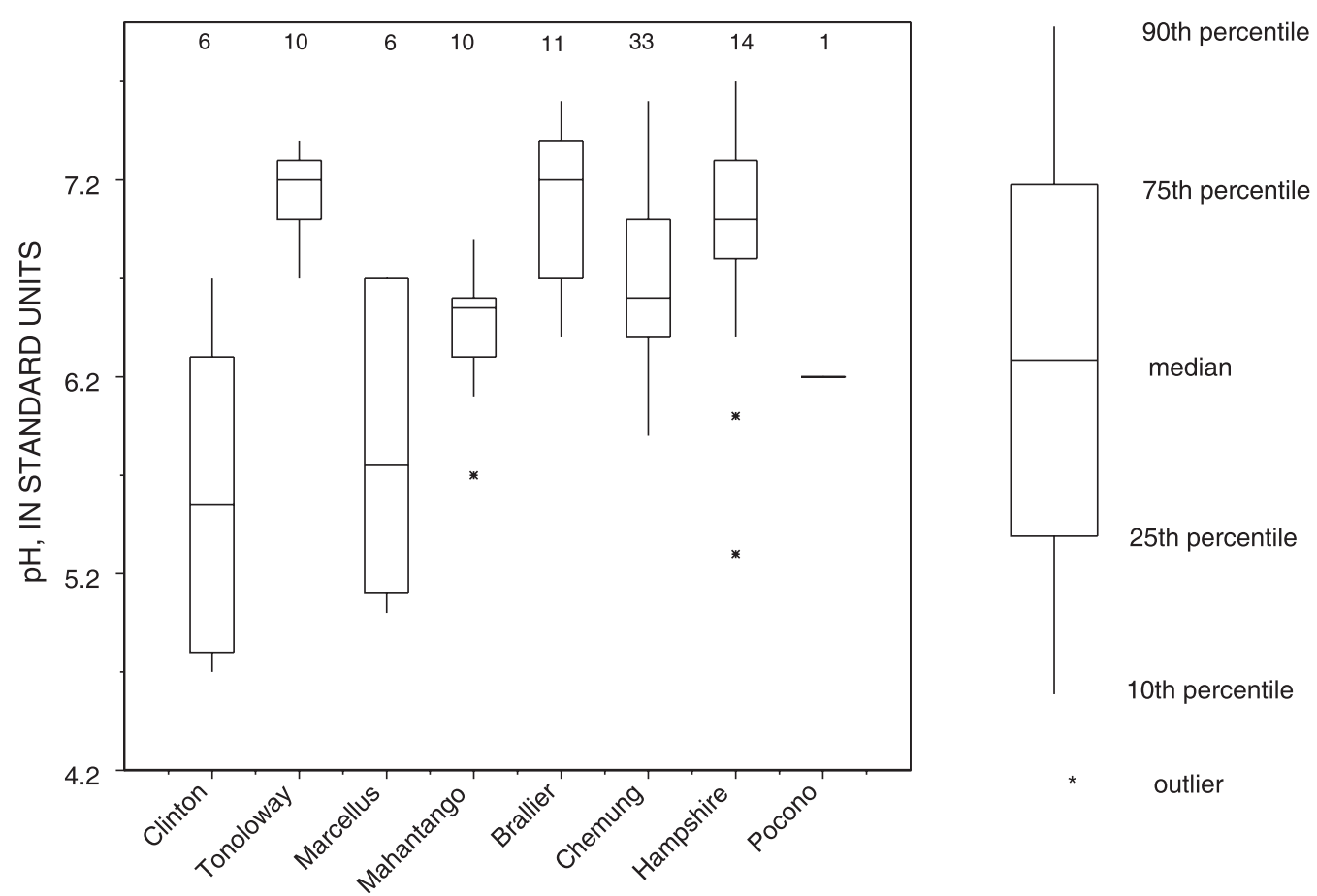

Figure 10. Distribution of $\mathrm{pH}$ values in ground-water samples from hydrogeologic units located in Morgan County, West Virginia.

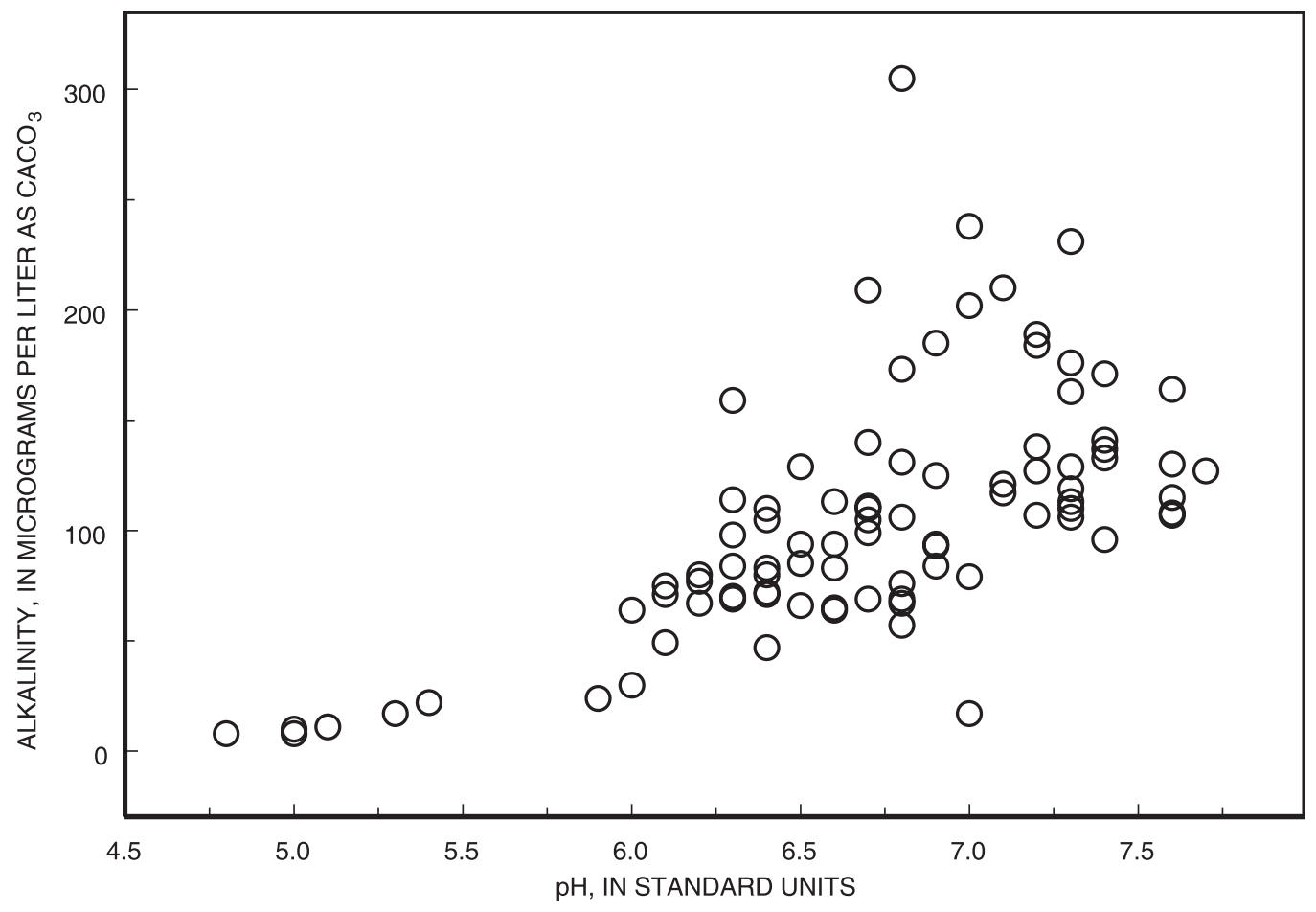

Figure 11. Relation between concentration of $\mathrm{pH}$ and alkalinity in ground-water samples from Morgan County, West Virginia. 


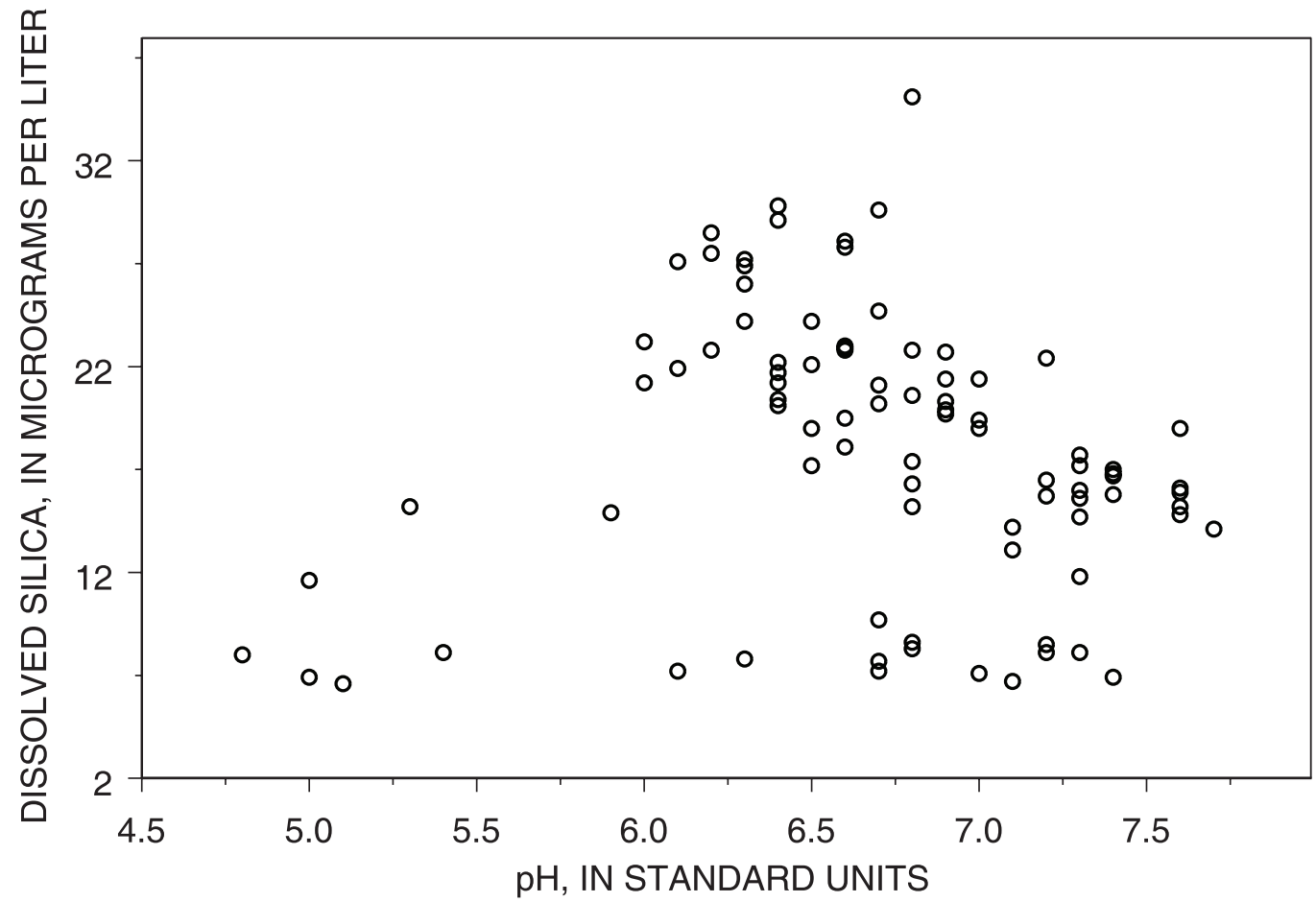

Figure 12. Relation between concentration of $\mathrm{pH}$ and dissolved silica in ground-water samples from Morgan County, West Virginia.

\section{EXPLANATION}

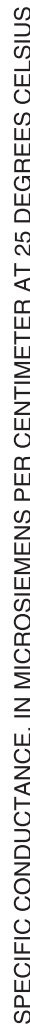

6 number of values

U
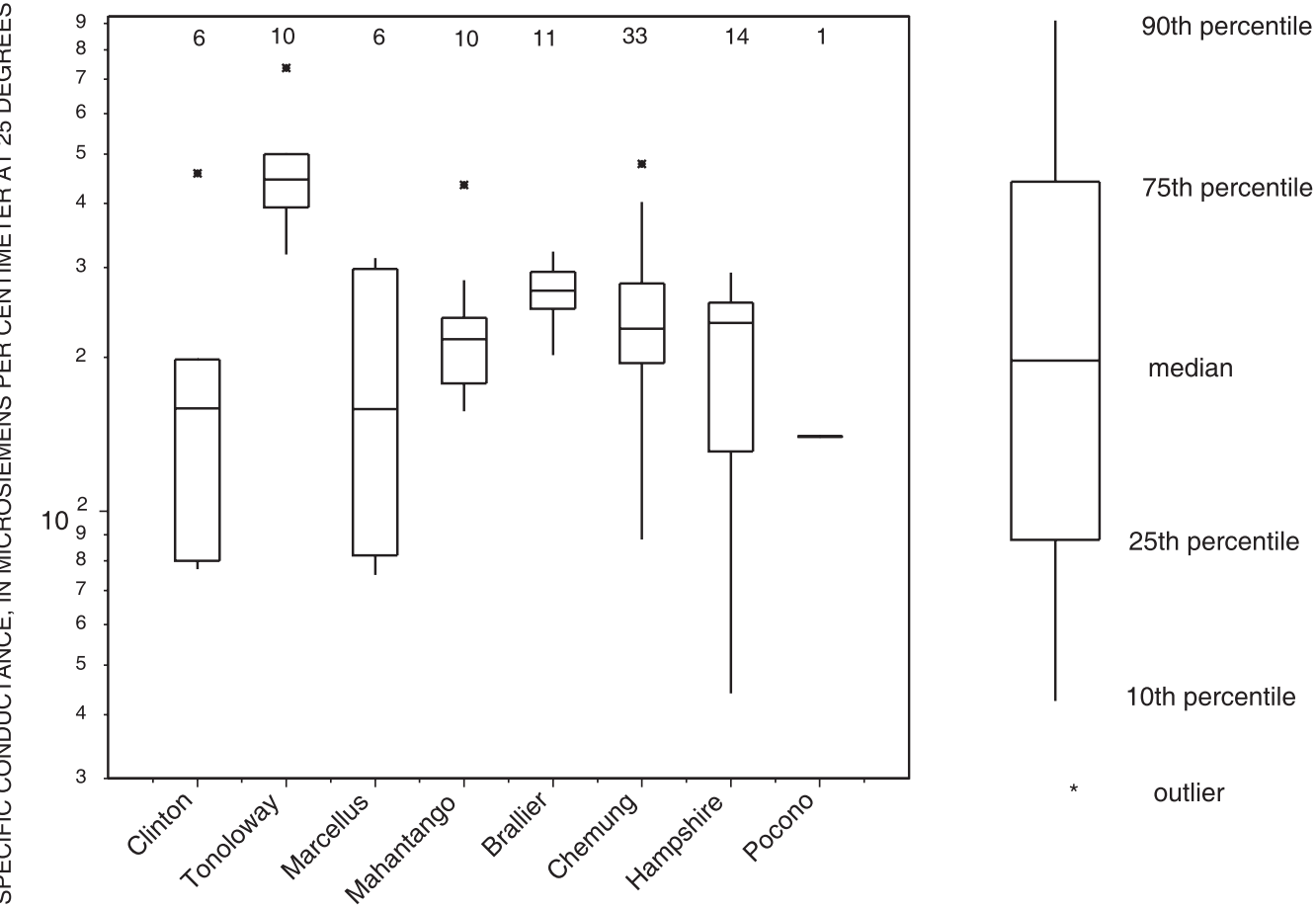

Figure 13. Distribution of specific conductance in ground-water samples from hydrogeologic units located in Morgan County, West Virginia. 


\section{Temperature}

Ground-water temperature responds to heat flow from the Earth's interior and, near the Earth's surface, seasonally variable heat from the sun (Heath, 1983). The near-surface, seasonally variable zone is approximately 30 to $80 \mathrm{ft}$ thick, and ground-water temperatures in that zone may vary seasonally by as much as 5 to $10^{\circ} \mathrm{C}$ (Heath, 1983). Mean annual groundwater temperature of this shallow zone is estimated to be in the range of 10 to $13^{\circ} \mathrm{C}$ in the study area (Heath, 1983). At depths below $100 \mathrm{ft}$ below land surface, ordinary geothermal temperature gradients range from approximately 0.6 to $0.7^{\circ} \mathrm{C}$ per $100 \mathrm{ft}$ (Driscoll, 1986). Elevated ground-water temperatures may indicate that the ground-water flow path is through a deep aquifer system in which geothermal heating has taken place. Meteoric water that is recharged at relatively high elevation on the crest or limb of an anticline may flow along bedding planes or fracture zones deep into an adjacent syncline where geothermal heating takes place. The flow then rises to or near the surface, where the same bed crops out in another anticline (Reeves, 1932) or through zones of weakness in the bedrock such as those caused by transverse or thrust faults. Perry and others (1979) evaluated geothermal heat flow in Bath County, Va., which lies in a physiographic setting similar to that found in Morgan County, W. Va. In that study, the Brallier Formation of Devonian age was found to have a geothermal gradient of approximately $0.4^{\circ} \mathrm{C}$ per $100 \mathrm{ft}$.

The ground-water temperature was measured at all well and spring sites in the study area. The temperatures measured at the well sites ranged from 10.9 to $16.0^{\circ} \mathrm{C}$ with a median temperature of $13.0^{\circ} \mathrm{C}$ (fig. 14). These temperatures indicate that ground water in the study area is derived from flow systems potentially ranging from a near-surface system, less than $200 \mathrm{ft}$ below land surface, to a system as deep as $1,500 \mathrm{ft}$ or more. However, depending upon the flow path, geothermally heated ground water may cool within the flow system before its interception by a well or its issuance at the surface.
EXPLANATION

6 number of values

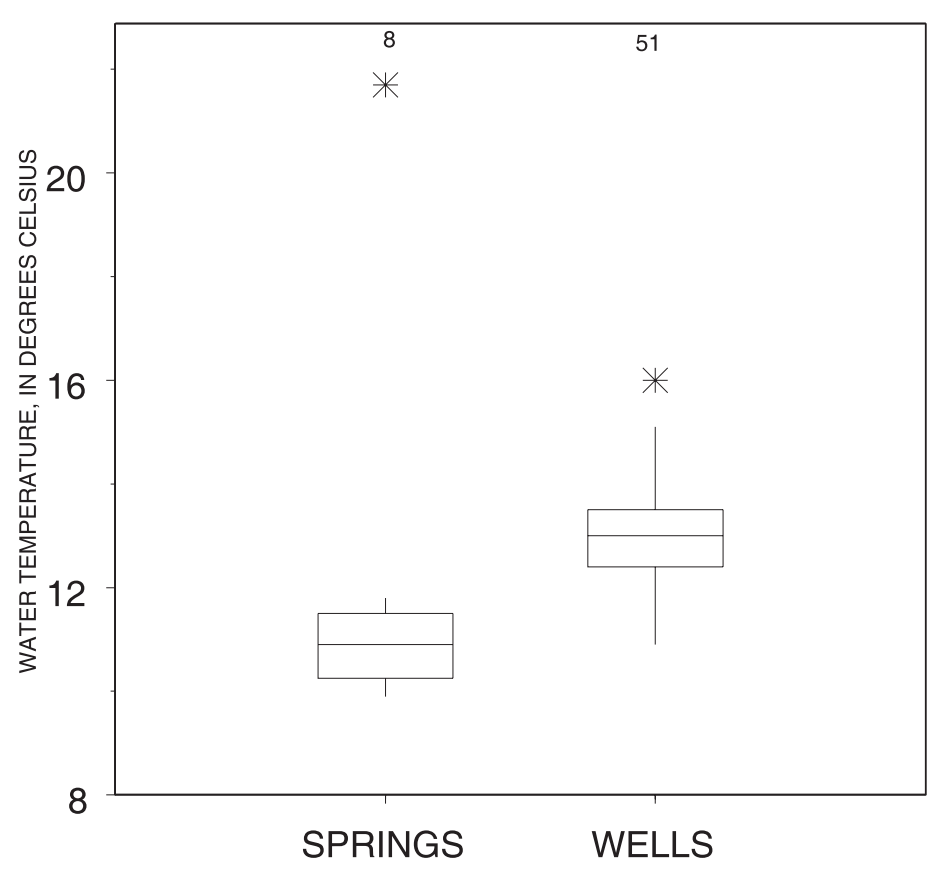

Figure 14. Distribution of temperature in ground-water samples from springs and wells located in Morgan County, West Virginia. 
Temperatures at the spring sites ranged from 9.9 to $21.7^{\circ} \mathrm{C}$. The median temperature of the springs was $10.9^{\circ} \mathrm{C}$. Lessing and others (1991) reported temperatures from geothermally heated warm springs in Morgan County ranging from $15.3^{\circ} \mathrm{C}$ at Hancock Spring to $22.2^{\circ} \mathrm{C}$ at Berkeley Springs. Hancock Spring was not sampled during the current study. The Berkeley Springs discharge from five major orifices, one of which is the Ladies Spring. The Ladies Spring (site 100) sample was $21.7^{\circ} \mathrm{C}$ and was the only spring sampled during this study that had a temperature indicative of a deep flow system. Water produced from the Marcellus Formation was generally warmer than the other formations, ranging from a minimum of $12.3^{\circ} \mathrm{C}$ to a maximum of $16.0^{\circ} \mathrm{C}$ and with a median of $13.8^{\circ} \mathrm{C}$ (fig. 15). Water produced from the Brailler Formation had a similar temperature profile, ranging from a minimum of $12.4^{\circ} \mathrm{C}$ to a maximum of $14.2^{\circ} \mathrm{C}$ and with a median of $13.9^{\circ} \mathrm{C}$. Water samples produced from the Mahantango Formation had the smallest temperature range from 11.6 to $13.0^{\circ} \mathrm{C}$ and a median of $12.4^{\circ} \mathrm{C}$. The results indicate that water sampled from the Marcellus and Brailler Formations may flow along deeper flow paths than those in the Mahantango Formation.

\section{Alkalinity}

Alkalinity is defined as the capacity of a solution to neutralize acid at a designated end-point. Alkalinity may be produced by noncarbonate anions such as sulfate, phosphate, and nitrate. However, in most natural water, nearly all alkalinity is produced by dissolved carbonate and bicarbonate and is commonly expressed in terms of equivalent calcium carbonate or carbonate alkalinity (Hem, 1985). Precipitation contains atmospheric carbon dioxide and dissolves additional carbon dioxide as it infiltrates through the soil zone. Carbonate rocks, such as limestone and dolomite, are composed primarily of calcium carbonate $\left(\mathrm{CaCO}_{3}\right)$. As ground water containing carbon dioxide comes in contact with carbonate rocks, the calcium carbonate in the rocks is dissolved, producing bicarbonate. The USEPA (2005b) has not established a water-quality standard for alkalinity. Concentrations of alkalinity in samples from the Tonoloway Formation were considerably larger than from any other aquifer. The median concentration of alkalinity for the Tonoloway Formation was $184 \mathrm{mg} / \mathrm{L}$, the minimum was $69 \mathrm{mg} / \mathrm{L}$, and the maximum was $305 \mathrm{mg} / \mathrm{L}$. The median

\section{EXPLANATION}

6

number of valu
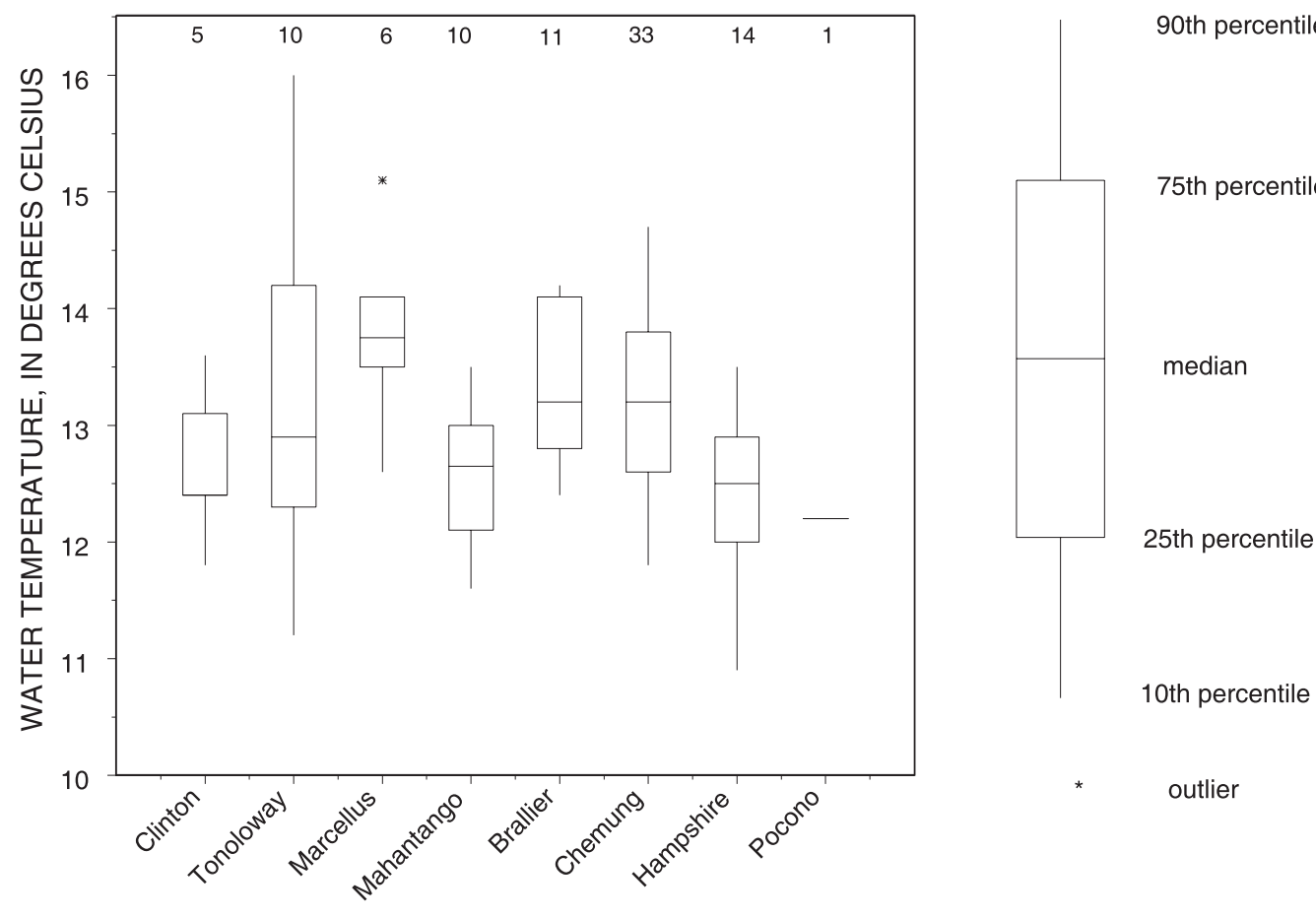

HYDROGEOLOGIC UNITS

Figure 15. Distribution of temperature in ground-water samples from hydrogeologic units located in Morgan County, West Virginia. 
concentration of alkalinity for all other ground-water samples was $94 \mathrm{mg} / \mathrm{L}$, the minimum concentration was $8 \mathrm{mg} / \mathrm{L}$, and the maximum was $238 \mathrm{mg} / \mathrm{L}$. The concentration of alkalinity of all of the ground-water samples collected was produced primarily by bicarbonate.

\section{Water Hardness}

Water hardness is caused primarily by calcium and magnesium ions in solution. In this report, the convention used for expressing hardness is "hardness as $\mathrm{CaCO}_{3}$ " and is calculated as described by (Hem, 1985). The USEPA (2005b) has not established a standard for hardness, which is typically associated with effects observed in the use of soap or with the encrustations left by some types of water when they are heated (Hem, 1985). Hardness is commonly classified as follows: soft (0 to $60 \mathrm{mg} / \mathrm{L}$ ); moderately hard (61 to $120 \mathrm{mg} / \mathrm{L}$ ); hard (121 to $180 \mathrm{mg} / \mathrm{L}$ ); and very hard (greater than $180 \mathrm{mg} / \mathrm{L}$ ) (Durfor and Becker, 1964). On the basis of those criteria, approximately 13 percent of the samples analyzed were soft water, 56 percent were moderately hard water, 18 percent were hard water, and 13 percent were very hard water. Ground-water hardness as $\mathrm{CaCO}_{3}$ in the Tonoloway Formation ranged from 80 to $400 \mathrm{mg} / \mathrm{L}$ with a median concentration of $220 \mathrm{mg} / \mathrm{L}$, considerably larger than from other aquifers. Concentrations of hardness as $\mathrm{CaCO}_{3}$ from all other formations ranged from 16 to $260 \mathrm{mg} / \mathrm{L}$ with a median concentration of $98 \mathrm{mg} / \mathrm{L}$.

\section{Dissolved Oxygen}

Oxygen is supplied to ground water through recharge and by movement of air through the unsaturated zone. Recharge water can be expected to contain concentrations of DO similar to surface water. The equilibrium concentration of DO in water is primarily a function of water temperature and atmospheric pressure. Traditional theory holds that water in deep ground-water systems is typically undersaturated with respect to oxygen. As ground water flows through an aquifer system, DO reacts with available, oxidizable, aquifer material such as pyrite $\left(\mathrm{FeS}_{2}\right)$ and siderite $\left(\mathrm{FeCO}_{3}\right)$ or naturally occurring organic material resulting in a decreased concentration of DO. In settings with shallow soil overlying permeable fractured rock, DO at detectable concentrations may persist throughout the flow system (Freeze and Cherry, 1979). Concentrations of DO from 2 to $8 \mathrm{mg} / \mathrm{L}$ have been measured in ground water from deep aquifers in the south-central Great Basin Physiographic Province (Fenneman, 1946). The residence time for ground water in these aquifers ranges from thousands to more than 10,000 years (Winograd and Robertson, 1982). Edmunds and others (1982) reported appreciable concentrations of DO in recently recharged water in a sandstone aquifer in England, whereas downdip concentrations of DO in the same aquifer were depleted to less than $0.1 \mathrm{mg} / \mathrm{L}$. Hydrogeochemical calculations resulted in an estimate of an approximate 5,000-year residence time for the water in that aquifer to have evolved to those low concentrations.

For this study, concentrations of DO ranged from estimated values of less than 0.1 to $10.3 \mathrm{mg} / \mathrm{L}$. The $10.3 \mathrm{mg} / \mathrm{L}$ concentration represents 100 percent saturation of DO at the measured temperature and barometric pressure. Water was observed to be cascading down the wellbore at sites 30, 39, 40, and 83 , and air bubbles became entrained within the homeowner's plumbing system at site 47; therefore, concentrations of DO at those locations are assumed to be elevated above that which would have occurred naturally within the aquifer. The concentration of DO at several other sites was elevated for no observed reason. It is possible that ground water flows so rapidly through the fracture systems that geochemical reduction of the concentration of DO is minimized. It also is possible that turbulent flow occurs within open fracture systems or solutionally enhanced conduits, thus entraining oxygen in place. Pumping with rapid drawdown in low-production domestic wells may induce mechanical entrainment of DO.

\section{Turbidity}

Turbidity is a measure of the cloudiness of water (U.S. Environmental Protection Agency, 2005b). Turbidity occurs naturally in ground water, depending upon the aquifer medium. Wells may produce nonturbid water at low pumping rates, but at higher pumping rates, turbidity may increase dramatically. The increased turbidity could be from turbid recharging water being pulled into the stressed aquifer or from turbulent flow that picks up sediment in fractures or conduits within the aquifer and suspends it in the ground water (Hobba and others, 1972). The maximum turbidity measured during this study was 330 nephelometric turbidity units (NTU), the median turbidity was 3.9 NTU, and 22 samples had turbidity of less than 1 NTU. USEPA has established a maximum for turbidity in public supply systems as 5 NTU prior to treatment, with more stringent requirements for public-water-supply systems that filter (U.S. Environmental Protection Agency, 2005b). USEPA requirements are established on the basis of turbidity caused by disease-causing organisms typically found in surface water, not ground water. Thirty-five of the wells sampled had turbidity measurements greater than 5 NTU at the pumping rates sustained over approximately a 30-minute time interval. Turbidity measurements typically did not stabilize, but increased throughout the pumping test, indicating that the aquifer could not sustain production at the indicated pumping rate without inducing turbidity.

\section{Inorganic Constituents}

Inorganic constituents are those that do not contain carbon. Ninety-one wells and eight springs were sampled in the study area for a variety of inorganic constituents; results are summarized in Appendixes 2 and 3, respectively. 


\section{Major lons}

Major inorganic ions are calcium, magnesium, sodium, potassium, bicarbonate, chloride, and sulfate, which typically occur in natural water in concentrations of $1 \mathrm{mg} / \mathrm{L}$ or larger. These constituents exist in pairs of cations and anions, which are indicative of the mineralogy of the hydrogeologic setting through which the water has flowed. For instance, calcium-bicarbonate- dominant ground water is indicative of a limestone aquifer, calcium-magnesium-bicarbonate water may be indicative of a dolomite aquifer, and sodium-chloride dominant ground water is typical of a sedimentary setting rich in evaporite salts. Geochemical characterization becomes more complex where the aquifer system consists of a mixture of rock types or if the ground water has flowed through differing types of rock units.

Ground water within a study area may be classified by use of a trilinear diagram suggested by Piper (Hem, 1985). To use this diagram, the concentration of each major cation and anion is expressed as a percentage of the total milliequivalents per liter in each sample. The percentage of major cations and anions in each sample is then plotted as a single point on the lower left and lower right triangles of the diagram, respectively. These points are projected to a single point on the plotting field, which lies between the two triangles. For example, if the point falls near the left point of the plotting field, then the water may be classified as a calcium-bicarbonate-type water. If a point falls near the lower right tip of the plotting field, the water is classified as a sodium-potassium-bicarbonate-type water. The trilinear method describes the percentage of the major cations and anions. That is, the percentage of each constituent or group of constituents is represented by where a point lies in the plotting field; however, this graphical method does not indicate the concentration of the dissolved constituents. Geochemical signatures of ground-water and spring samples analyzed for this study are shown in figure 16.

The predominant geochemical signature of ground water and spring water in Morgan County was calcium-bicarbonatetype water; however, there also were vastly differing groundwater samples with predominantly sodium-bicarbonate and predominantly calcium-magnesium-sulfate signatures.

Most of the spring-water samples were of the calciumbicarbonate type (fig. 16). A distinct exception was that of spring site 94 at Cacapon State Park, which showed a calcium-sulfate-chloride signature similar to that of the Marcellus Formation. Spring site 93 has a geochemical signature that lies between the calcium-bicarbonate and calcium-sulfate-chloride signatures, indicating that the ground water has flowed through some combination of limestone and shale units and plots close to ground-water samples from the Hampshire Formation (fig. 16).
The Pocono Group, Chemung Group, and Hampshire and Tonoloway Formations produce predominantly calcium-bicarbonate waters. Some samples had an elevated sulfate signature. Hobba and others (1972) attributed the possible source of an increased sulfate signature in the Tonoloway Formation as the presence of anhydrite $\left(\mathrm{CaSO}_{4}\right)$ and salt $(\mathrm{NaCl})$ deposits. Anhydrite and salt are known to occur at depth west of the study area but generally are thought to have been removed by ground-water circulation in the Potomac River Basin; however, residual deposits that have not been completely dissolved remain in rocks in the study area. The Hampshire Formation and Chemung Group also had some samples that had an increased sodium-bicarbonate signature. One sample (site 8) that is mapped at the surface in the Hampshire Formation had a nearly 100 percent sodium-bicarbonate composition, a very soft water. A narrow section of the Onesquethaw Group occurs at the surface near that well location. Deposits of glauconite, which is used as water softener, are known to occur in that group. Thicknesses of the Hampshire Formation and underlying units are not well known in that area, which is structurally complex. It is possible that the $300 \mathrm{ft}$ well at that site is tapping water that originates from the Onesquethaw Group. Most samples from the Clinton Formation had a calcium-bicarbonate signature, with one exception: a calcium-sodium sulfate water that bore a signature similar to that from a warm spring in the Oriskany Sandstone (Hobba and others, 1972).

\section{Bromide and Fluoride}

In addition to chloride, analyses were done for two other halides: bromide and fluoride. USEPA (2005b and d) has not established a drinking-water standard currently (2006) for bromide. The largest concentration of bromide detected was $0.13 \mathrm{mg} / \mathrm{L}$ at one site. USEPA (2005b and d) has established standards for fluoride. An MCL of $4.0 \mathrm{mg} / \mathrm{L}$ is established on the basis of potential health effects, including bone disease or mottled teeth. The SMCL of $2.0 \mathrm{mg} / \mathrm{L}$ is established for naturally occurring fluoride that may cause tooth discoloration or pitting during the formative period prior to eruption of teeth in children (U.S. Environmental Protection Agency, 2005d). None of the spring or well samples had concentrations of fluoride greater than the MCL or the SMCL. Approximately 42 percent of the samples had concentrations lower than the detection limit of $0.2 \mathrm{mg} / \mathrm{L}$. The largest concentration was $0.3 \mathrm{mg} / \mathrm{L}$, at three sites. 
SPRING WATER

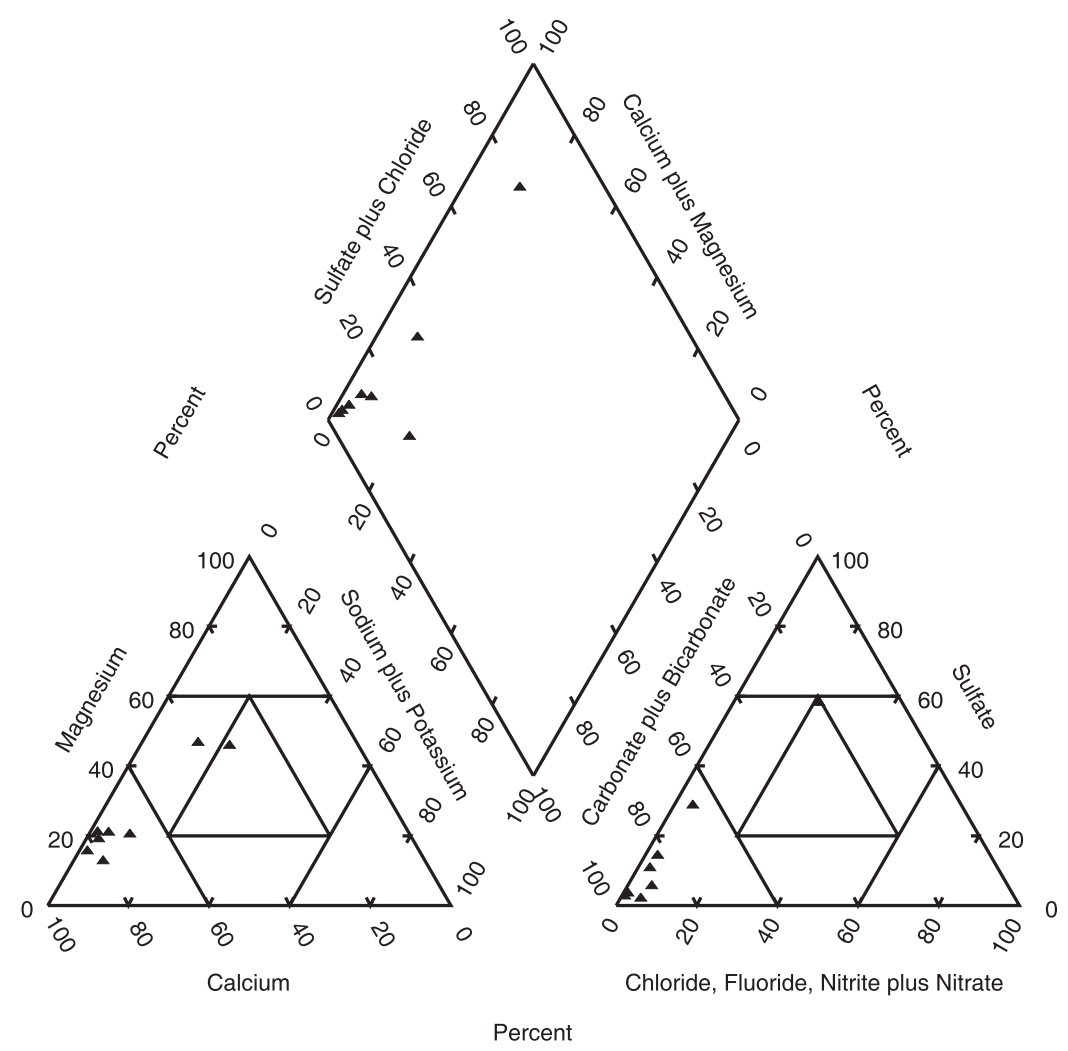

CLINTON GROUND WATER

(B)

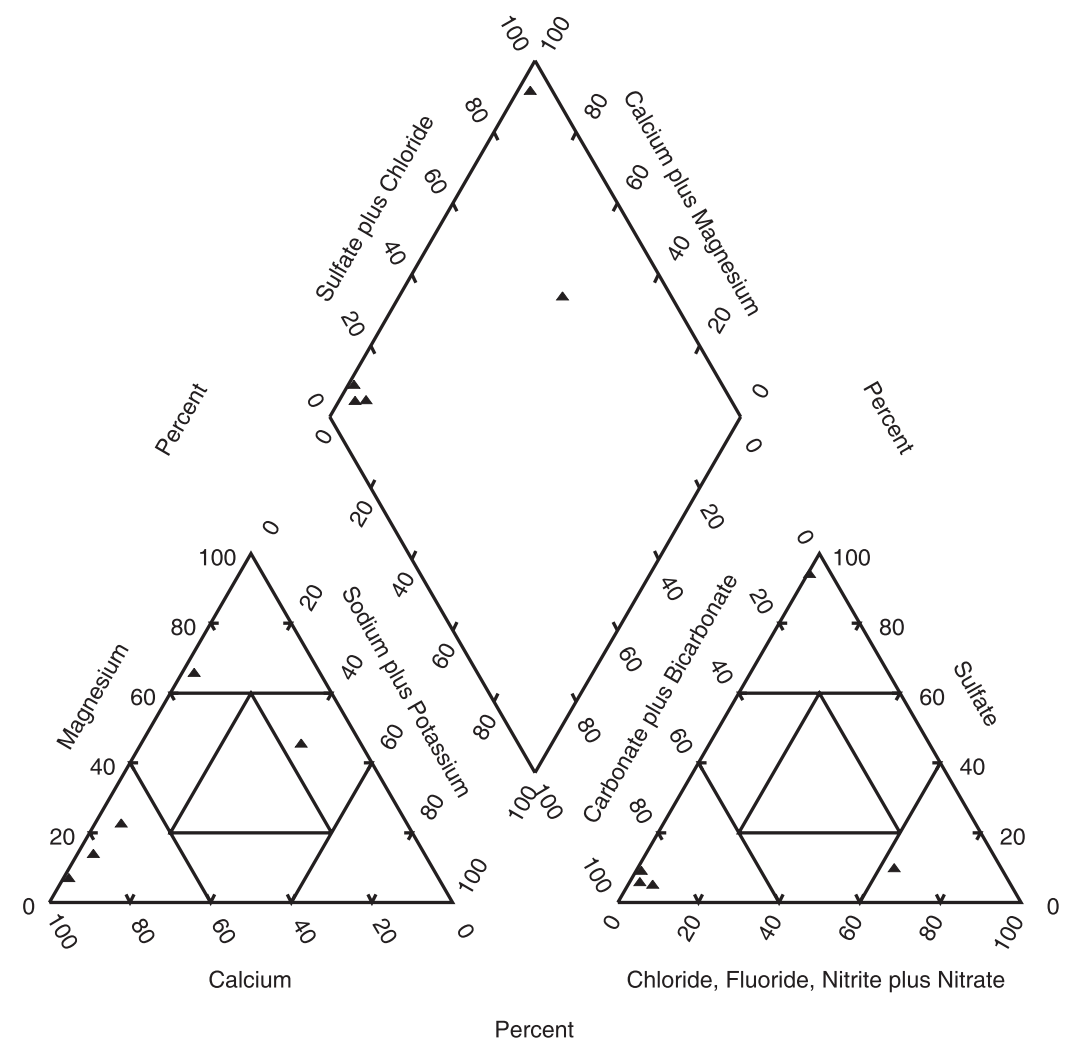

Figure 16. Relative geochemical composition of ground water from springs and wells, by hydrogeologic unit, Morgan County, West Virginia. 
TONOLOWAY GROUND WATER

(C)

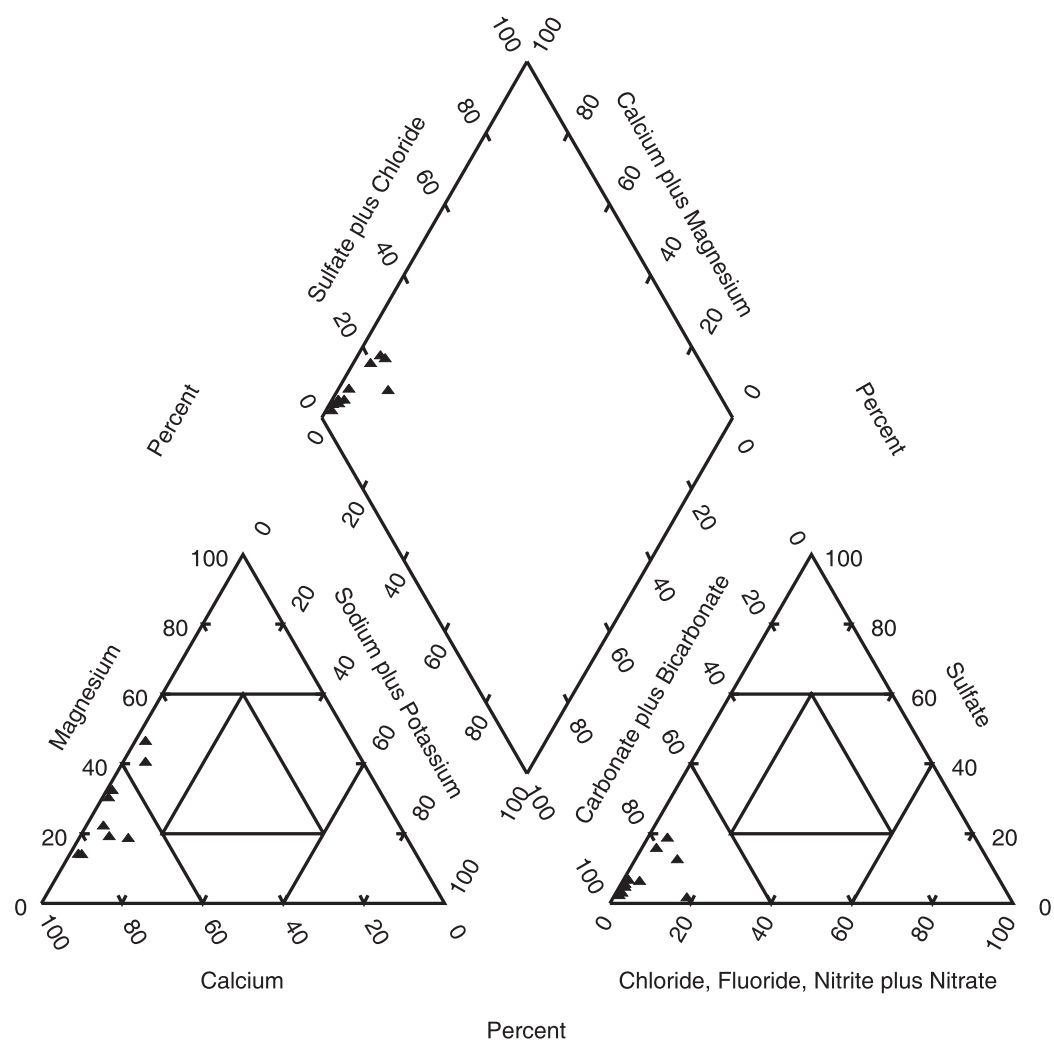

MARCELLUS AND MAHANTANGO GROUND WATER

(D)

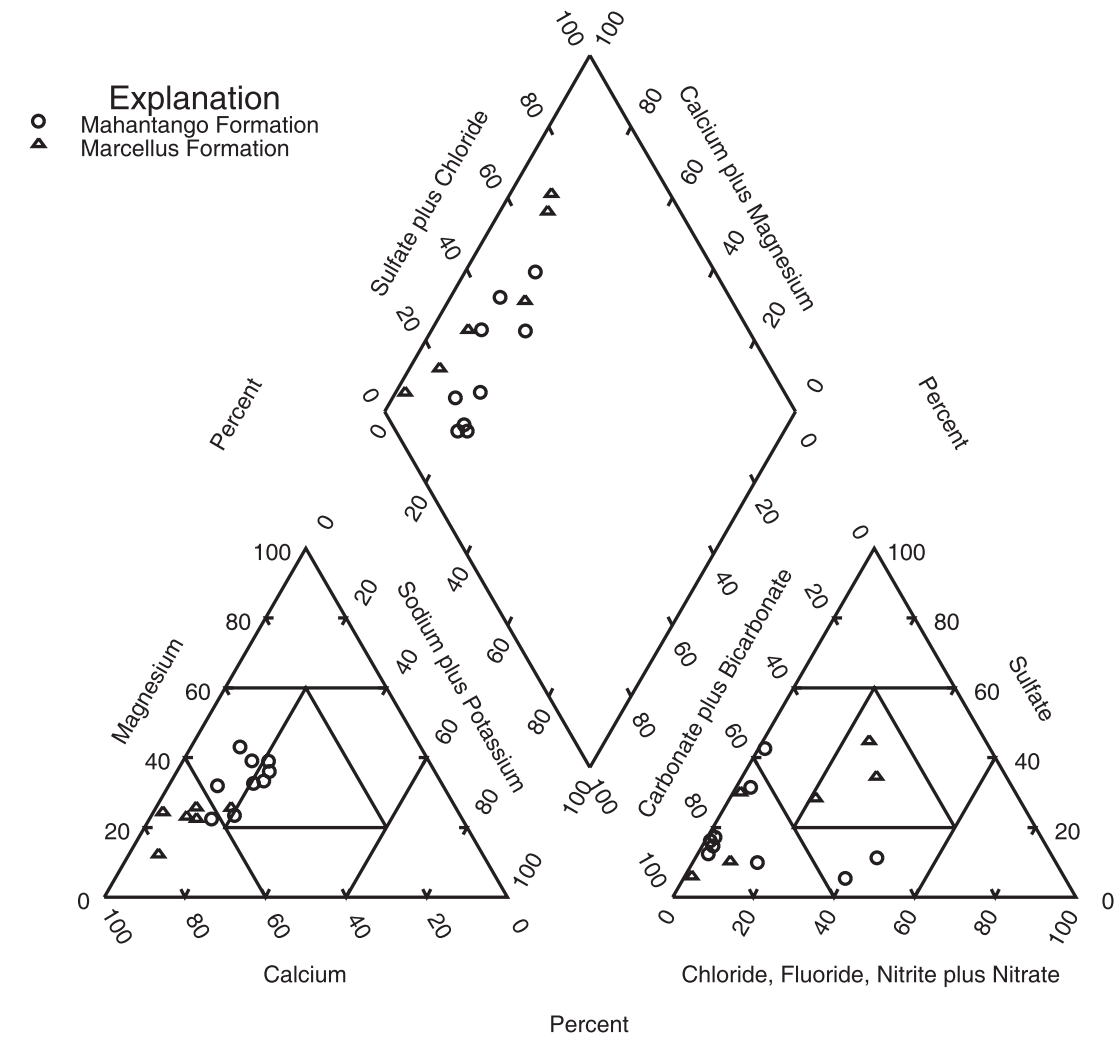

Figure 16. Relative geochemical composition of ground water from springs and wells, by hydrogeologic unit, Morgan County, West Virginia.—Continued 


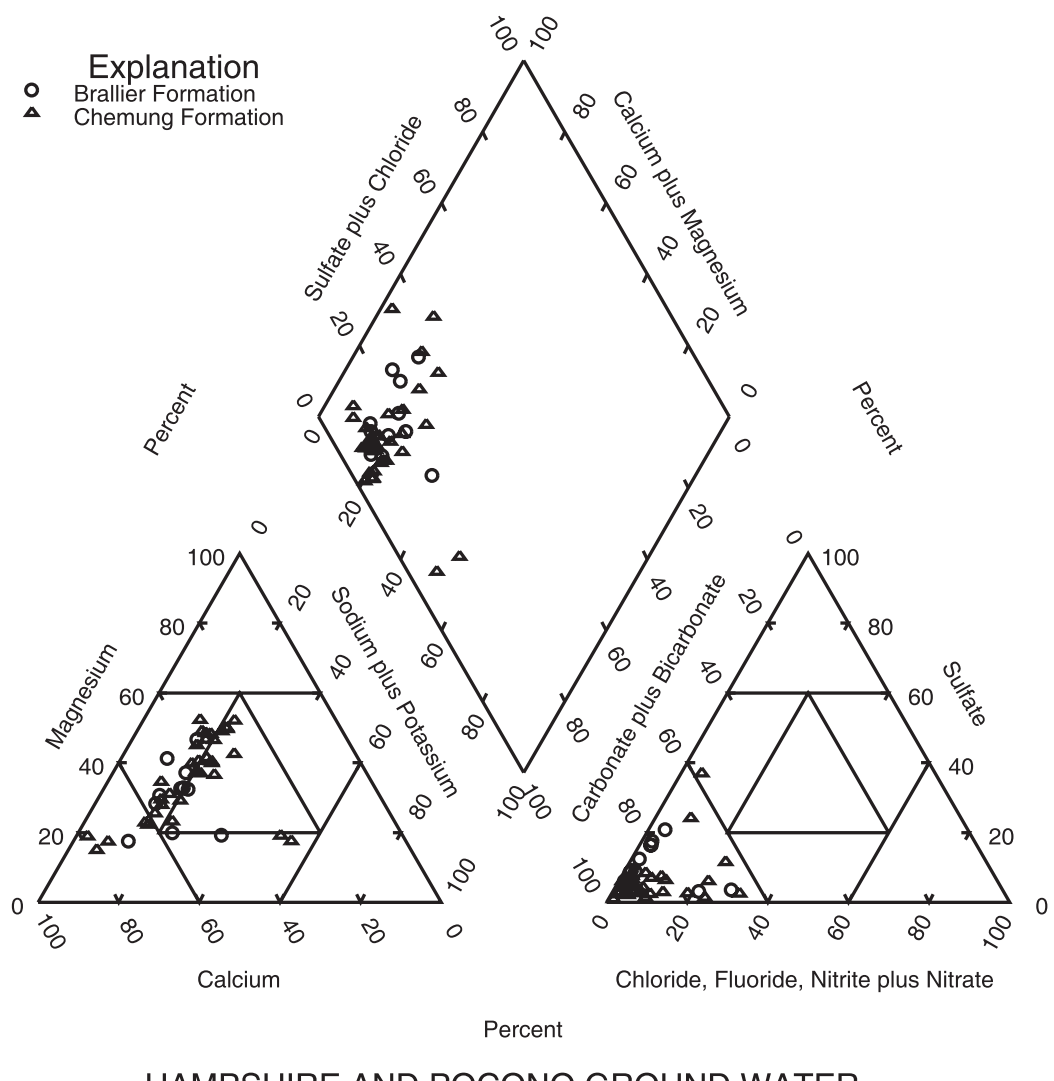

HAMPSHIRE AND POCONO GROUND WATER

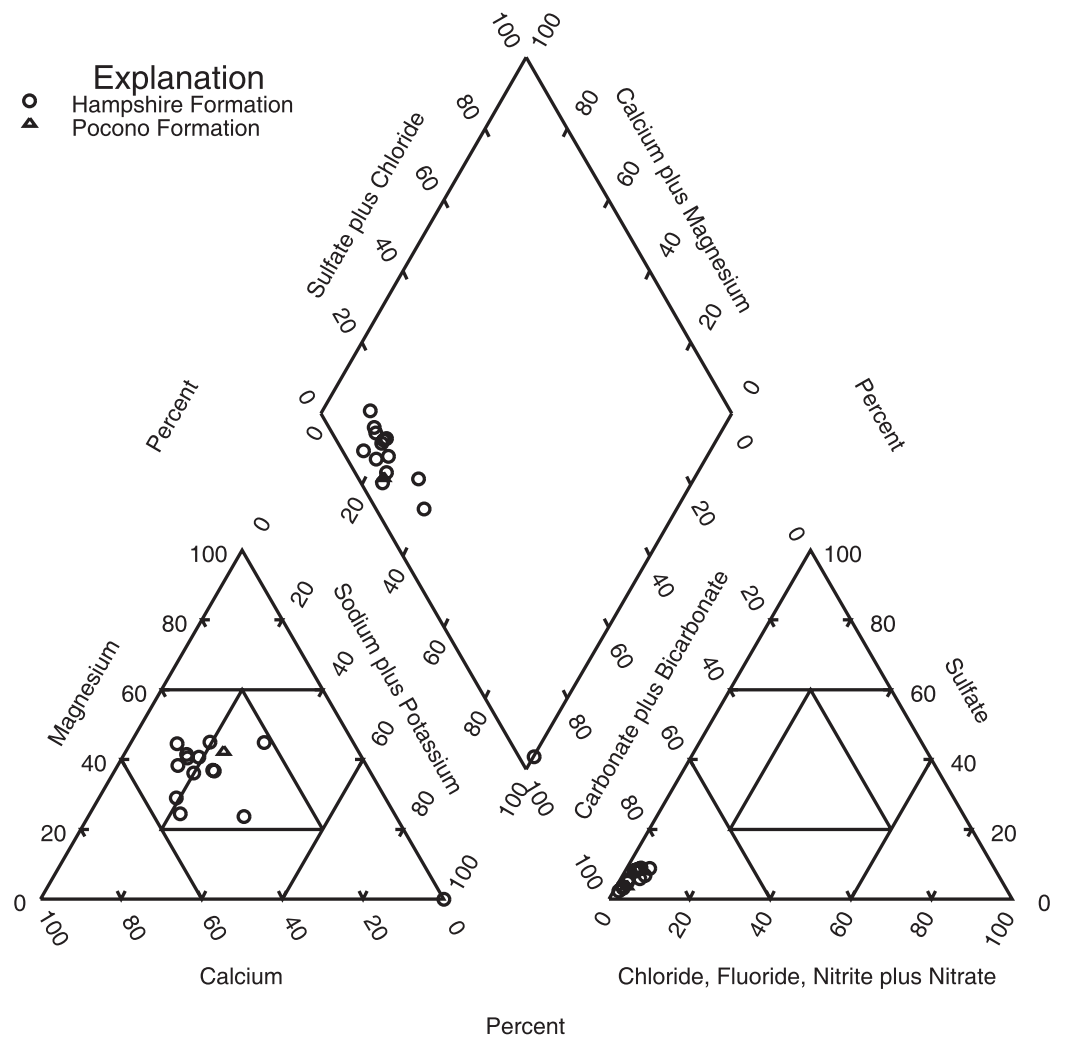

Figure 16. Relative geochemical composition of ground water from springs and wells, by hydrogeologic unit, Morgan County, West Virginia.-Continued 


\section{Iron and Manganese}

Trace concentrations of iron and manganese occur naturally in many rocks and soils as various mineral assemblages. Martens (1945) reported deposits of limonite $\left(\mathrm{Fe}_{2} \mathrm{O}_{3} \cdot \mathrm{H}_{2} \mathrm{O}\right)$, an iron ore mineral occurring 6 mi west of Hedgesville, near the eastern boundary of Morgan County. The deposits are neither large nor of sufficiently high quality to be of contemporary commercial interest. Their occurrence does provide insight as to one potential source of large concentrations of iron in ground water. Concentrations of dissolved iron greater than the SMCL of $300 \mu \mathrm{g} / \mathrm{L}$ typically precipitate when exposed to air or to DO in water and may cause turbidity, staining, and objectionable taste and color, and may corrode pipes, pumps, or other equipment (U.S. Environmental Protection Agency, 2005d). With the exception of the Tonoloway Formation and the one sample from the Pocono Group, ground water with concentrations of dissolved iron greater than $300 \mu \mathrm{g} / \mathrm{L}$ was found in all formations throughout the study area (fig. 17).

Ground water with a concentration of dissolved iron of at least $300 \mu \mathrm{g} / \mathrm{L}$ occurred in approximately 32 percent of the wells sampled (Appendix 2). The maximum concentration of dissolved iron in all ground-water samples was $24,100 \mu \mathrm{g} / \mathrm{L}$ and the median was $42 \mu \mathrm{g} / \mathrm{L}$. The maximum concentration of dissolved iron in spring-water samples (site 93) was $2,010 \mu \mathrm{g} / \mathrm{L}$. The concentration of dissolved iron in all other spring-water samples was less than the detection limit of $6 \mu \mathrm{g} / \mathrm{L}$.

Dissolved manganese in excess of the SMCL of $50 \mu \mathrm{g} / \mathrm{L}$ may result in black to brown color, black staining, and a bitter taste in the water (U.S. Environmental Protection Agency, 2005d). The maximum concentration of dissolved manganese in all ground-water samples was $3,920 \mu \mathrm{g} / \mathrm{L}$ (fig. 18) and the median was $106.5 \mu \mathrm{g} / \mathrm{L}$. The maximum concentration of dissolved manganese in spring-water samples was $212 \mu \mathrm{g} / \mathrm{L}$. The median concentration of dissolved manganese from all springwater samples was $0.60 \mu \mathrm{g} / \mathrm{L}$. Ground water with concentrations of dissolved manganese greater than $50 \mu \mathrm{g} / \mathrm{L}$ was found in all formations (fig. 18). Approximately 60 percent of the ground-water samples had concentrations of dissolved manganese greater than the SMCL (U.S. Environmental Protection Agency, 2005d).

The concentrations of iron and manganese are positively related (fig. 19). If the concentration of iron is small at a site, the concentration of manganese tends to be small. If the concentration of iron is large at a site, the concentration of manganese generally is large also.

\section{EXPLANATION}

6 number of values
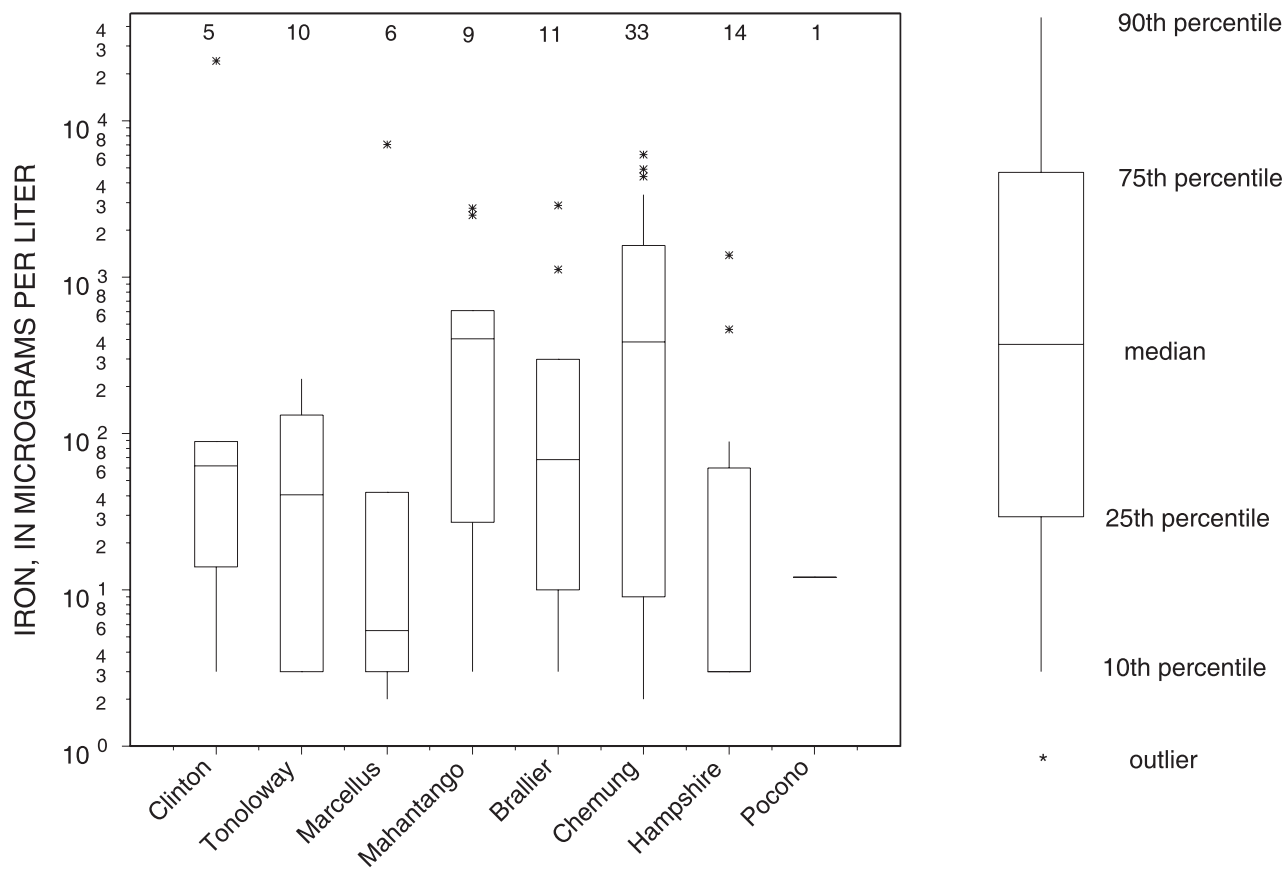

HYDROGEOLOGIC UNITS

Figure 17. Distribution of concentrations of iron in ground-water samples from hydrogeologic units located in Morgan County, West Virginia. 
EXPLANATION

6 number of values
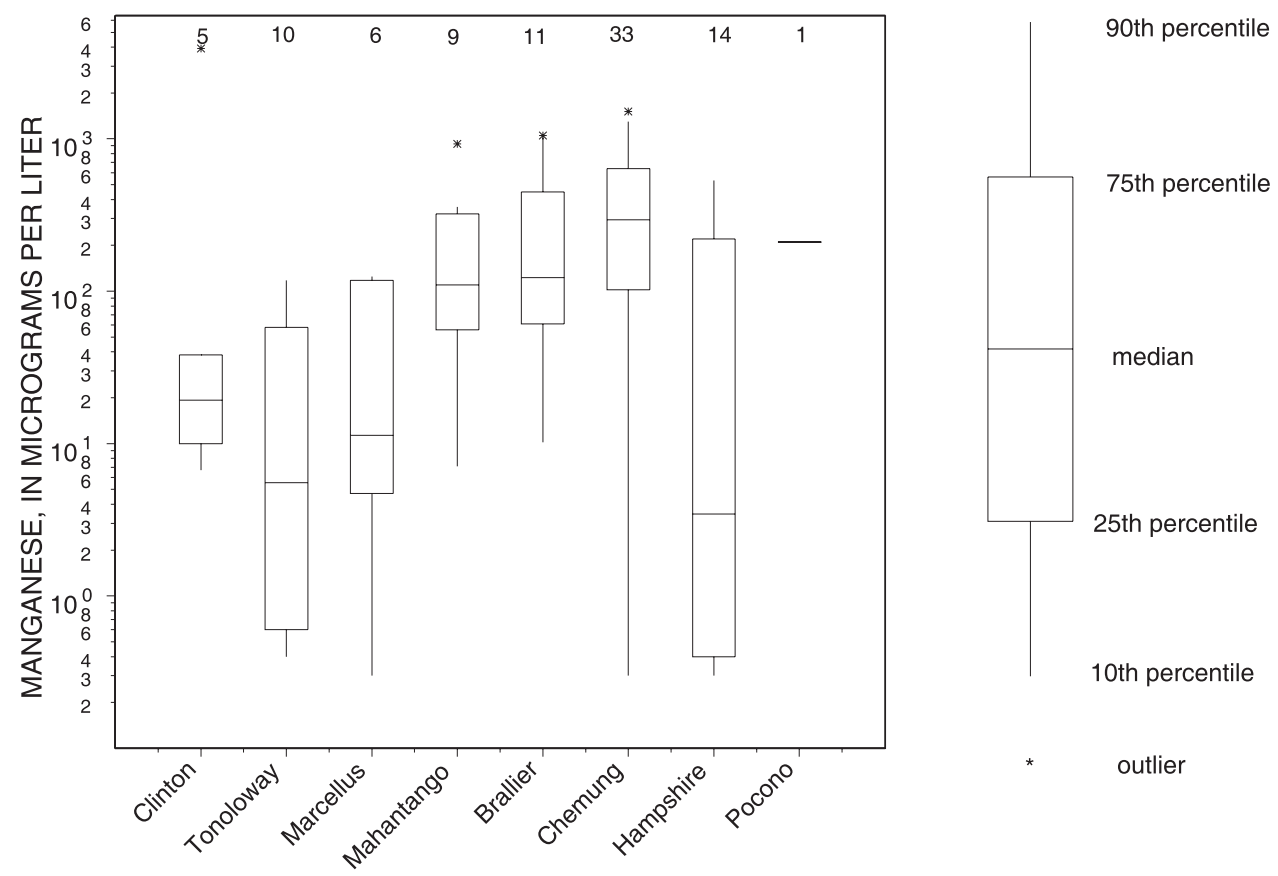

Figure 18. Distribution of concentrations of manganese in ground-water samples from hydrogeologic units located in Morgan County, West Virginia.

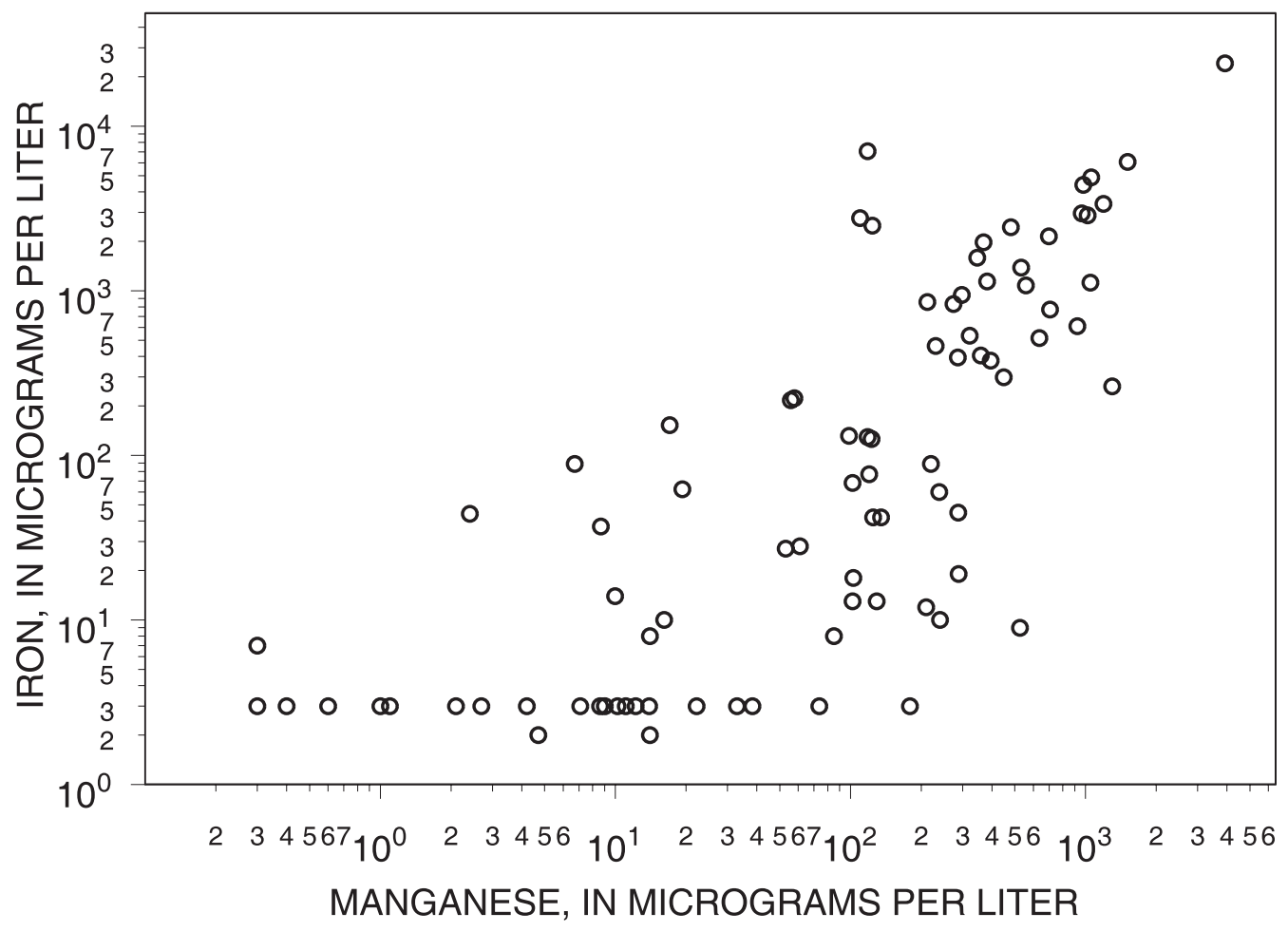

Figure 19. Relation between concentrations of iron and manganese in ground-water samples from Morgan County, West Virginia. 


\section{Trace Elements}

Trace elements occur in aquifer systems in which naturally occurring geochemical conditions are favorable for dissolving the elements from assemblages in the rock matrix. Trace elements sampled at a subset of sites were aluminum, arsenic, antimony, barium, cadmium, lead, nickel, strontium, and zinc.

The SMCL for aluminum (U.S. Environmental Protection Agency, 2005d) is a range from 50 to $200 \mu \mathrm{g} / \mathrm{L}$. Aluminum may cause colored water, scaling, and sedimentation (U.S. Environmental Protection Agency, 2005d). The maximum concentration of aluminum sampled was $2,340 \mu \mathrm{g} / \mathrm{L}$, with nine of the samples equal to or greater than the 50- $\mu \mathrm{g} / \mathrm{L}$ SMCL. Those samples were from the Brallier Formation, Chemung Group, and Clinton and Hampshire Formations. Five samples had concentrations less than the detection limit of $2 \mu \mathrm{g} / \mathrm{L}$. Those samples occurred in the same formations and in the Tonoloway Formation. The median concentration of aluminum was $10 \mu \mathrm{g} / \mathrm{L}$.

The MCL for antimony is $6 \mu \mathrm{g} / \mathrm{L}$ (U.S. Environmental Protection Agency, 2005b). The potential health effects from exposure above that MCL are an increase in blood cholesterol and a potential for blood sugar to be decreased. Antimony was not detected in any sample at the minimum detection level of $0.20 \mu \mathrm{g} / \mathrm{L}$.

The USEPA MCL for arsenic is $10 \mu \mathrm{g} / \mathrm{L}$ (U.S. Environmental Protection Agency, 2005b). Concentrations of arsenic greater than the MCL may cause skin damage, problems with circulatory systems, or increased risk of cancer (U.S. Environmental Protection Agency, 2005b). The maximum concentration of arsenic sampled was $8 \mu \mathrm{g} / \mathrm{L}$, with no sample concentrations greater than the $10 \mu \mathrm{g} / \mathrm{L}$ MCL. Eighteen samples had concentrations less than the detection limit of $2 \mu \mathrm{g} / \mathrm{L}$.

The MCL for barium is $200 \mu \mathrm{g} / \mathrm{L}$ (U.S. Environmental Protection Agency, 2005b). Barium in concentrations exceeding the MCL may cause an increase in blood pressure (U.S. Environmental Protection Agency, 2005b). The maximum concentration of barium sampled was $390 \mu \mathrm{g} / \mathrm{L}$, with nine sample concentrations great than the $200-\mu \mathrm{g} / \mathrm{L}$ MCL. Those samples came from the Brallier Formation, Chemung Group, and Clinton, Hampshire, and Tonoloway Formations. The smallest concentration of barium detected was $16.9 \mu \mathrm{g} / \mathrm{L}$ and the median concentration was $76 \mu \mathrm{g} / \mathrm{L}$.

The MCL for cadmium is $5 \mu \mathrm{g} / \mathrm{L}$ (U.S. Environmental Protection Agency, 2005b). Concentrations of cadmium exceeding the MCL may cause kidney damage. The maximum concentration of cadmium sampled was $0.5 \mu \mathrm{g} / \mathrm{L}$. None of the sample concentrations were greater than the $5-\mu \mathrm{g} / \mathrm{L} \mathrm{MCL}$. The smallest concentration of cadmium was $0.02 \mu \mathrm{g} / \mathrm{L}$ and the median concentration was $0.04 \mu \mathrm{g} / \mathrm{L}$.

The MCL for lead is an action level of $15 \mu \mathrm{g} / \mathrm{L}$ (U.S. Environmental Protection Agency, 2005b). For infants and children, lead may delay physical and mental development and cause slight deficits in attention span and learning abilities. For adults, concentrations of lead exceeding the MCL may cause kidney problems or high blood pressure. The maximum concentration of lead detected was $1.7 \mu \mathrm{g} / \mathrm{L}$ with 10 sample concentrations less than the detection limit of $0.05 \mu \mathrm{g} / \mathrm{L}$. The median concentration of lead was $0.04 \mu \mathrm{g} / \mathrm{L}$.

No MCL or SMCL currently (2006) exists for nickel (U.S. Environmental Protection Agency, 2005b and d). The maximum concentration of nickel detected was $30.6 \mu \mathrm{g} / \mathrm{L}$, and the median concentration was $1.78 \mu \mathrm{g} / \mathrm{L}$. Two samples had concentrations less than the detection limit. The three samples with the largest concentrations occurred in the Hampshire Formation.

No MCL or SMCL currently (2006) exists for elemental strontium (U.S. Environmental Protection Agency, 2005b and d). The maximum concentration of strontium detected was $5,520 \mu \mathrm{g} / \mathrm{L}$. The smallest concentration of strontium was $8.87 \mu \mathrm{g} / \mathrm{L}$ and the median concentration was $87.6 \mu \mathrm{g} / \mathrm{L}$. The three samples with the largest concentrations were from the Hampshire Formation.

The SMCL for zinc is $500 \mu \mathrm{g} / \mathrm{L}$ (U.S. Environmental Protection Agency, 2005d). Concentrations of zinc exceeding the SMCL may give a metallic taste to the water. The maximum concentration of zinc sampled was $696 \mu \mathrm{g} / \mathrm{L}$, the only concentration greater than the 500- $\mu \mathrm{g} / \mathrm{L}$ SMCL; the sample was from the Marcellus Formation. The median concentration was $46.0 \mu \mathrm{g} / \mathrm{L}$. Eleven samples had concentrations below the detection limit of 6-micrograms per liter.

Zinc and aluminum occur contemporaneously in the study area (fig. 20). The concentration of zinc is generally small at sites with a small concentration of aluminum. With little exception, the concentration of aluminum is large at site with a large concentration of zinc. A less strong positive relation exists between concentrations of strontium and lead.

\section{Nutrients}

All samples were analyzed for the following nutrients: ammonia, nitrate-plus-nitrite, nitrate, total phosphorus, and orthophosphate. The occurrence of nutrients in ground water at elevated concentrations frequently is caused by contamination from septic tank effluent, confined animal-feedlot operations, or fertilizer application. At elevated concentrations, certain nutrients may cause adverse effects on human health.

\section{Nitrate and Nitrite}

Small concentrations of nitrogen species occur naturally in rocks. Soils and biological matter contain larger concentrations of nitrogen species. In ground water, nitrate is usually the only nitrogen form of significance, although nitrogen species may occur at all oxidation states from -3 to +5 , depending upon conditions (Hem, 1985). 


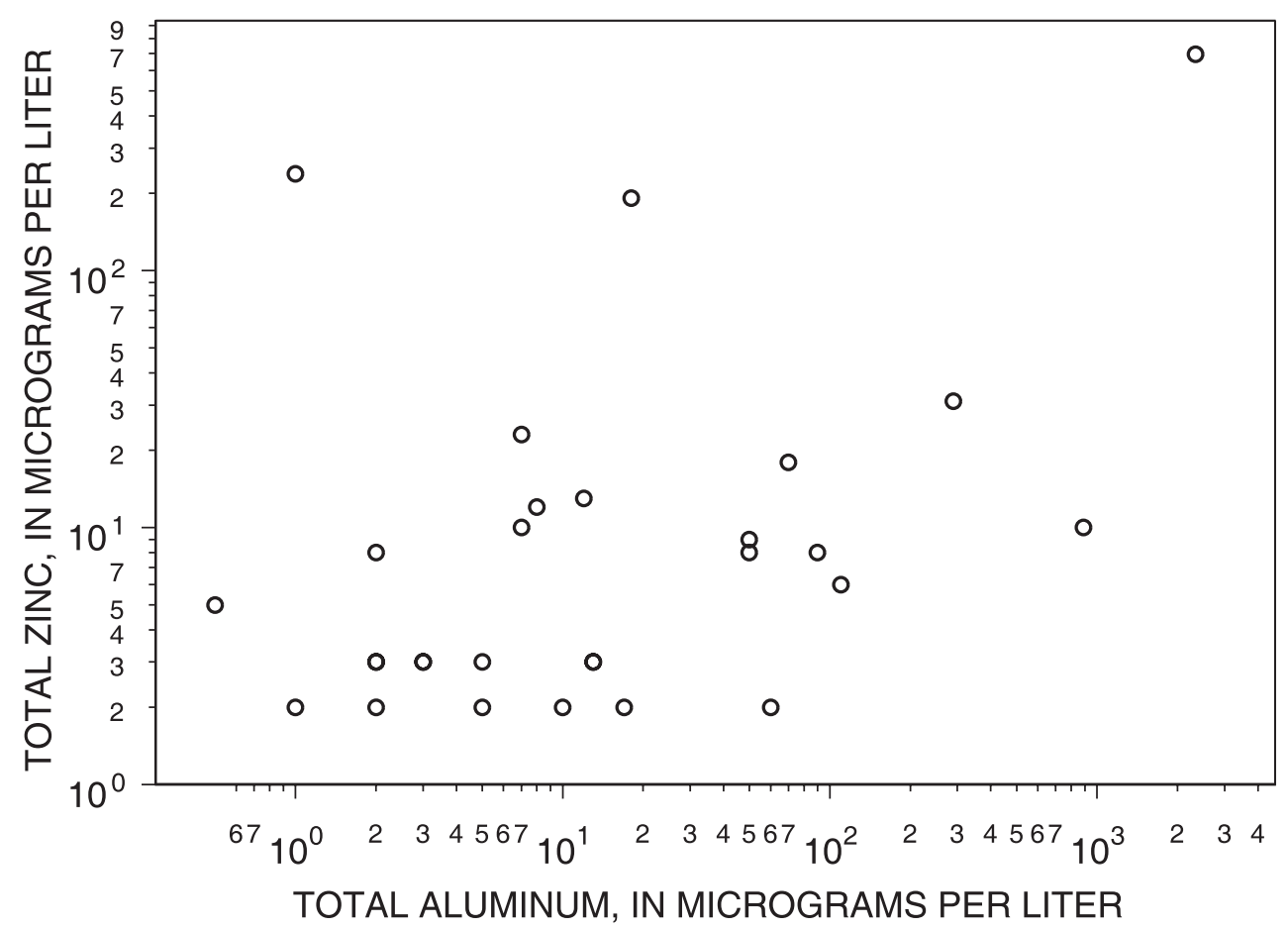

Figure 20. Relation between concentrations of zinc and aluminum in ground-water samples from Morgan County, West Virginia.

USEPA has established MCLs for nitrate of $10 \mathrm{mg} / \mathrm{L}$ as $\mathrm{N}$ and for nitrite of $1.0 \mathrm{mg} / \mathrm{L}$ as N (U.S. Environmental Protection Agency, 2005a). Infants below the age of 6 months may suffer from an acute condition known as methemoglobinemia (blue-baby syndrome) from water containing concentrations that exceed the MCLs. Nitrates and nitrites also have the potential to cause diuresis, increased starchy deposits, and hemorrhaging of the spleen from long-term exposures at concentrations exceeding the MCLs (U.S. Environmental Protection Agency, 2005b).

The largest concentration of nitrate-plus-nitrite as $\mathrm{N}$ was $2.6 \mathrm{mg} / \mathrm{L}$, and 69 percent of the samples had concentrations less than the detection limit of $0.06 \mathrm{mg} / \mathrm{L}$. The maximum concentration of nitrite as $\mathrm{N}, 0.042 \mathrm{mg} / \mathrm{L}$, was the only value larger than the minimum reporting level (MRL), $0.008 \mathrm{mg} / \mathrm{L}$, although there are several estimated values below the MRL.

\section{Ammonia Species}

The sources of ammonia species in natural water are assumed to be similar to those of other nitrogen species and typically are transformed to nitrate; however, ammonia is present in some natural waters (Hem, 1985). The largest concentration of ammonia as $\mathrm{N}$ detected during this study was
$0.20 \mathrm{mg} / \mathrm{L}$, and approximately 70 percent of the samples had concentrations less than the detection limit of $0.04 \mathrm{mg} / \mathrm{L}$. No MCL or SMCL currently (2006) exists for ammonia in drinking water (U.S. Environmental Protection Agency, 2005b).

\section{Phosphorous and Orthophosphate}

Phosphorous occurs in a wide range of oxidation states in natural water; the most probable species are phosphate anions, complexes with metal ions, and colloidal particulate material (Hem, 1985). Phosphorous, as an element essential for animal metabolism, is always present in animal metabolic waste (Hem, 1985). As such, its presence in large concentrations may indicate contamination from animal or human waste. No MCL or SMCL currently (2006) exists for phosphorous or orthophosphate in drinking water (U.S. Environmental Protection Agency, 2005b).

The largest concentration of phosphorous detected during this study was $0.25 \mathrm{mg} / \mathrm{L}$ and more than 85 percent of the samples had concentrations less than the detection limit of $0.04 \mathrm{mg} / \mathrm{L}$. The largest concentration of orthophosphate as $\mathrm{P}$ was $0.17 \mathrm{mg} / \mathrm{L}$ and more than 84 percent of the samples had concentrations less than the detection limit of $0.02 \mathrm{mg} / \mathrm{L}$ (U.S. Environmental Protection Agency, 2005b). 


\section{Radon-222}

Radon-222 is a radioactive gas that occurs naturally as a decay product of uranium. Radon-222 gas is dissolved in ground water and degasses when the water is exposed to the open atmosphere. It can enter homes when water valves are opened, particularly during the use of showers. Rocks that are known to have a high uranium content include granitic rocks, some volcanic rocks, dark shales, sedimentary rocks that contain phosphate, and metamorphic rocks derived from these rocks (Otton and others, 1993). The accumulation and transport of radon in the subsurface depends upon the uranium content, grain size, permeability, and the extent of fracturing in the host rock. The rocks of Morgan County include dark shales and other sedimentary rocks that can contain uranium.

Radon-222 can destroy lung tissue and cause lung cancer (Otton and others, 1993) or can cause stomach cancer (U.S. Environmental Protection Agency, 2005c). In 1999, USEPA reinstated a proposed enforceable maximum contaminant level (PMCL) for radon in drinking water of $300 \mathrm{pCi} / \mathrm{L}$, but with an alternate maximum contaminant level (AMCL) proposed at a concentration of $4,000 \mathrm{pCi} / \mathrm{L}$. The drinking- water standard that would apply for a community water system (CWS) would depend upon whether or not the State or CWS develops a radon Multimedia Mitigation (MMM) program. If a CWS serves 10,000 persons and either the State or the system has an approved MMM program, then the $4,000 \mathrm{pCi} / \mathrm{L}$ AMCL would apply; otherwise, the $300 \mathrm{pCi} / \mathrm{L}$ standard would apply. USEPA further proposes a nonenforceable Maximum Contaminant Level Goal (MCLG) of zero for radon-222 in drinking water (U.S. Environmental Protection Agency, 2005c). MCLGs are defined by USEPA as the level of a contaminant in drinking water below which there is no known or expected risk to health. MCLGs allow for a margin of safety and are nonenforceable public-health goals.

Radon-222 was detected in all wells sampled, ranging from 10 to $2,170 \mathrm{pCi} / \mathrm{L}$, with a median value of $365 \mathrm{pCi} / \mathrm{L}$. The two samples from the Clinton Formation had radon-222 concentrations much larger than the other formations, 1,330 and 2,170 pCi/L. Concentrations in 56 percent of the samples were greater than the PMCL of $300 \mathrm{pCi} / \mathrm{L}$. Concentrations in none of the samples were greater than the proposed AMCL of $4,000 \mathrm{pCi} / \mathrm{L}$ (fig. 21).

\section{EXPLANATION}

6 number of values
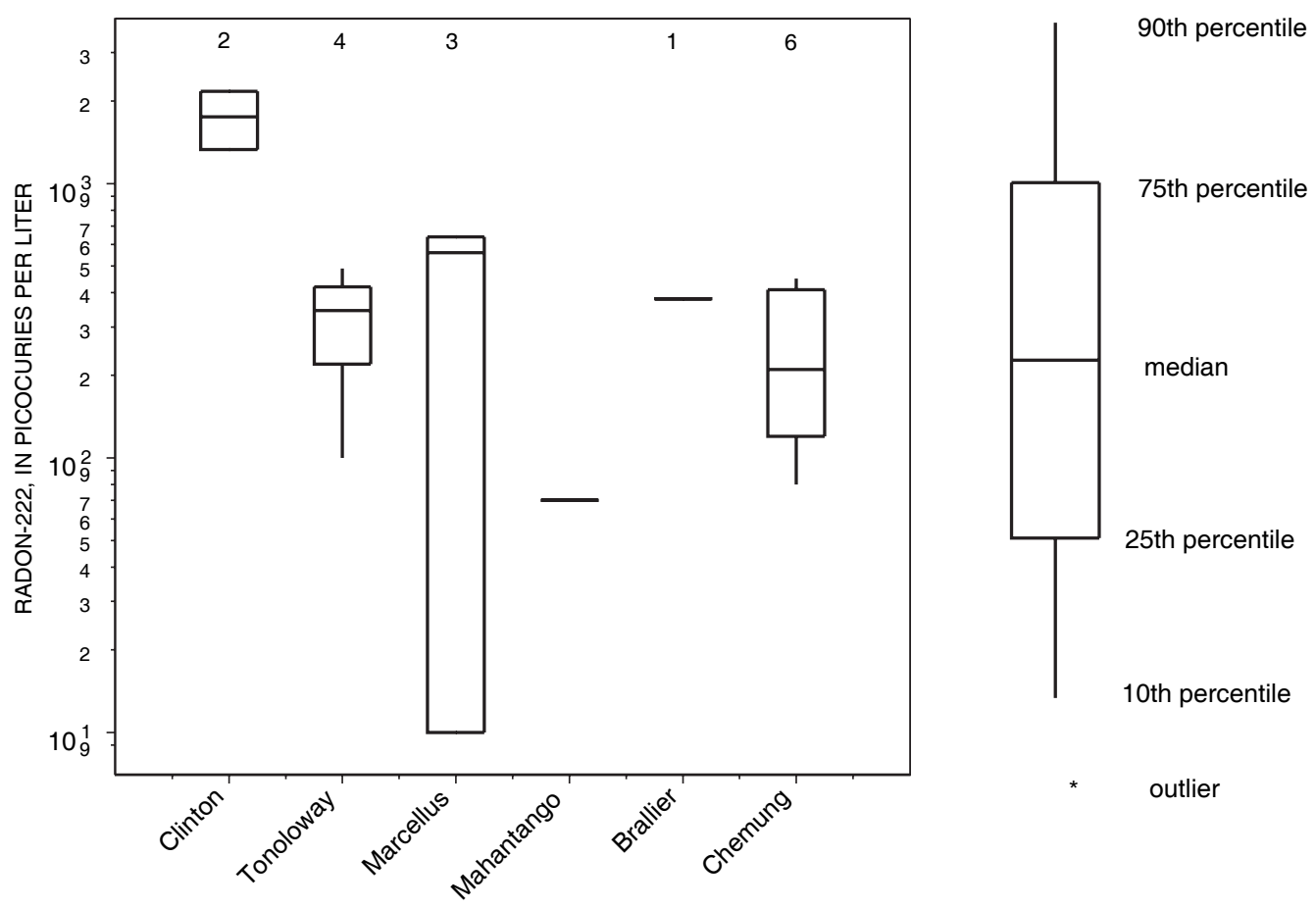

Figure 21. Distribution of concentration of radon-222 in ground-water samples from hydrogeologic units located in Morgan County, West Virginia. 


\section{Bacteria}

Well and spring samples were tested for fecal coliform bacteria, total coliform bacteria, and Escherichia coli (E. coli). These microorganisms occur in the feces of warmblooded animals, including humans. The presence of these microorganisms indicates the presence of fecal contamination and the possible presence of other harmful bacteria, viruses, or other pathogens into the ground-water system. Certain strains of E. coli are of particular concern because they can cause health problems such as fever, diarrhea, and, in certain instances, kidney failure (U.S. Centers for Disease Control and Prevention, 2005). USEPA has established an MCLG for total coliforms (including fecal coliform and E. coli) of zero colonies per 100 milliliters (col/100 mL) for public drinking water supply systems (U.S. Environmental Protection Agency, 2005a).

Ninety-one wells in the study area were tested for coliform bacteria. Fecal coliform bacteria were detected in 5 ground-water samples ( 5 percent), total coliform bacteria were detected in 42 ground-water samples ( 46 percent), and E. coli were detected in 2 ground-water samples (2 percent).

Approximately 69 percent of the wells sampled were constructed after 1983 and constructed with a grout surface seal (West Virginia Bureau for Public Health, 1984). West Virginia Bureau for Public Health (1984) requires installation of a concrete pad around the casing at the surface but does not require grouting the entire length of the casing. Proper surface seals and grouting of wells helps to reduce the potential for transport of fecal contaminants along the casing from the surface to the aquifer. The casings of most of the wells sampled appeared to be in good condition at the surface, although no downhole observations were possible. Additionally, most of the wells were located at a distance from potential fecal-material sources such as barnyard manure or pet waste. Proper siting of wells with respect to septic systems can reduce or eliminate the potential of microbial transport through the aquifer from that source.

The occurrence of total coliform bacteria was compared with geologic unit, age of well, depth of well, the ratio of well depth to casing length, and aquifer transmissivity as determined during the recovery phase of the aquifer test. No significant correlation was found among the occurrence of total coliform bacteria and any of these characteristics. Wellsite proximities to septic systems were not evaluated as part of this study.

Mathes (2000) studied the relation of bacteria to septic systems in Berkeley County, W. Va., and found no apparent relation among septic-system density and the concentration of bacterial colonies detected. This lack of correlation was attributed to the structural complexity of the limestone aquifers in the study area. The geology in Morgan County is equally complex. Soils are generally shallow, and all of the bedrock units have undergone faulting, folding, and fracturing. Septic systems sited on shallow soils may result in percolation through underlying fractures, where contamination may be transported rapidly into the aquifer. Mathes (2000) found little difference in the frequency of total coliform bacteria between shallow wells and deep wells. Similarly, no correlation was found during this study. Mathes (2000) also found that the greatest concentrations of $E$. coli and fecal coliform bacteria were in shallow wells. No such correlation was found during this study; however, evaluation of well-completion reports for Morgan County indicates that well production in the domestic wells frequently consists of two or more fracture zones. The uppermost fracture zone is frequently at a depth of less than $100 \mathrm{ft}$ below land surface, and produces 1 to $2 \mathrm{gal} / \mathrm{min}$, inadequate for a domestic supply well. Drilling is continued until another fracture zone is penetrated, providing a combined production adequate to supply domestic needs. The upper zones are rarely grouted; therefore, the potential exists for contamination from shallower zones even in deep wells.

The ratio of well depth to casing length was developed and correlated with the occurrence of total coliform bacteria. No significant correlation exists; however, the sites with the largest total coliform bacteria concentration had a ratio of total well depth to casing length less than or equal to 0.35 (fig. 22). The most contaminated site with a ratio exceeding 0.35 was a newly constructed well, which may have had residual contamination from drilling. In highly folded, faulted, and fractured terrain, longer grouted casings may be needed to protect underlying aquifers.

Eight springs were sampled for the presence of bacteria. No bacteria were detected in two of the eight springs. Total coliform bacteria were detected in six of the springs, and E. coli were detected at two spring sites.

Natural springs are open to the surrounding environment and are therefore susceptible to microbial contamination by feces from wildlife or domestic animals that frequent the area. Properly constructed spring houses can protect a water source from fecal contamination. The two springs that were free from coliform bacteria have enclosed spring structures. With the exception of one free-flowing, natural spring, all of the springs tested were protected by spring houses or spring boxes. The structures varied significantly from site to site. At one site, frogs were observed in a spring house that had an unscreened discharge pipe that could serve as an opening for other animals to enter. No inventory of potential sources of contamination was done during the course of this study. 


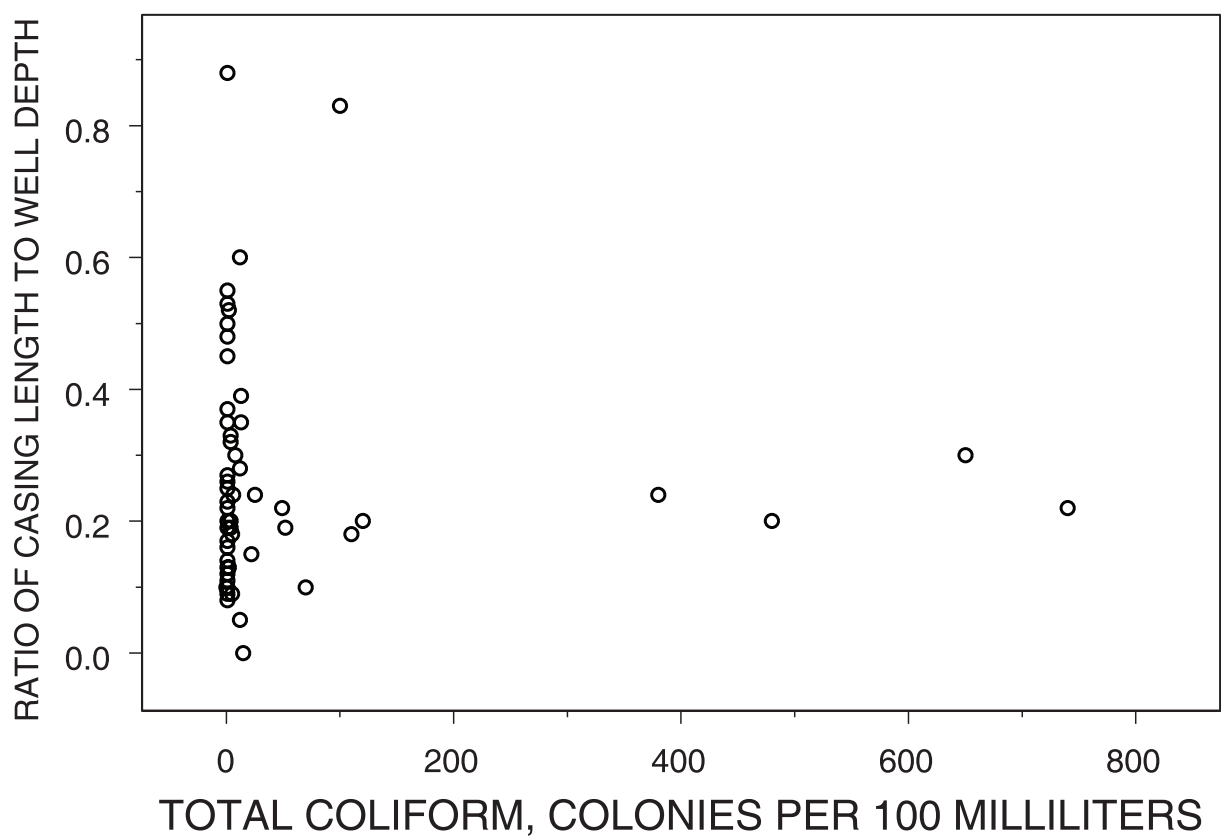

Figure 22. Relation between the ratio of casing length to well depth and the occurrence of bacteria in wells located in Morgan County, West Virginia.

\section{Summary and Conclusions}

With few exceptions, municipal and private users in the study area depend upon ground water for their water supplies. Aquifers in Morgan County are composed of carbonate, sandstone, and shale rocks of ages ranging from Late Ordovician to Early Mississippian. The rocks are characterized by thin to thick bedded formations. Interbedding occurs among the various limestones, shales, sandstones, and siltstones that includes calcareous shale and sandstone and cherty limestone and shale. The hydrogeology is complicated by the structural complexity typical of the Valley and Ridge Physiographic Province. That structural complexity consists of a series of steeply dipping north-south trending anticlines, synclines, and thrust faults that are intersected by cross-faulting in several locations throughout the study area.

Static ground-water altitudes decrease from recharge areas in the mountains to the valley floors. Along the valley floors, altitudes decrease from the southern part of the county to the Potomac River in the north. Thus, ground water ultimately flows in a northerly direction. Small drainages have developed where cross-faulting or jointing occurs and these drainages provide local recharge zones. Static water levels may vary among nearby or adjacent sites by as much as $200 \mathrm{ft}$ in some localities because of the complexity of the geologic stratigraphy and structure. This variability also may indicate the presence of separate or otherwise isolated aquifers at different depths because of the local structural complexity.

Transmissivities were determined for aquifers throughout the study area. Transmissivities ranged from 2 to $1,420 \mathrm{ft}^{2} / \mathrm{d}$. The largest transmissivities generally occurred at or near contacts between geologic units (at bedding planes) or in the presence of thrust-faults or cross-faults. Small transmissivities (less than or equal to $5 \mathrm{ft}^{2} / \mathrm{d}$ ) occurred in all aquifer units except the Marcellus Formation, which had transmissivities ranging from 54 to $327 \mathrm{ft}^{2} / \mathrm{d}$ and had the largest median transmissivity at $128 \mathrm{ft}^{2} / \mathrm{d}$. The largest transmissivity recorded was $1,490 \mathrm{ft}^{2} / \mathrm{d}$ from the Chemung Group, but near a bedding contact with the Brallier Formation. Production from wells within the study area is typically from one or two fracture zones.

Water quality and geochemistry are variable throughout the county and within aquifer units. Geochemically, the ground water ranges from nearly 100 percent sodium-bicarbonate water to nearly 100 percent calcium-magnesium-sulfate-chloride water as end-members. Most of the water tested is calcium-bicarbonate water, which is typical of water from a limestone aquifer. Geochemical mixing has occurred among or within aquifer units.

Water-quality characteristics for which values were greater than U.S. Environmental Protection Agency Maximum Contaminant Levels or Secondary Maximum Contaminant Levels include radon-222, pH, turbidity, iron, manganese, aluminum, and total- and fecal-coliform and E. coli bacteria. Concentrations of radon-222 were greater than the $300 \mathrm{pCi} / \mathrm{L}$ Proposed Maximum Contaminant Level in more than half of the wells tested. Total coliform occurred in 42 wells, fecal coliform in 5 wells, and E. coli in 2 wells. More than 35 percent of the wells tested had turbidity greater than 5 NTU. The largest measurement was 330 NTU. Pumping stress on aquifers with low production tended to increase turbidity. Specific conductance (SC) ranged from 44 to $737 \mu \mathrm{S} / \mathrm{cm}$. The median $\mathrm{SC}$ was $240 \mu \mathrm{S} / \mathrm{cm}$. Hardness as $\mathrm{CaCO}_{3}$ ranged from 16 to $400 \mathrm{mg} / \mathrm{L}$. The median hardness was $98 \mathrm{mg} / \mathrm{L}$. 


\section{Acknowledgments}

The authors thank Danny Evans of the West Virginia Conservation Agency and the Eastern Panhandle Conservation District for their cooperation in this study. We also gratefully acknowledge the Morgan County Rural Water Committee and the Morgan County Planning Commission for their assistance and West Virginia University for their collaboration during the course of the study. We particularly thank the many individuals, establishments, and authorities in the county that permitted access to their wells for collection of hydraulic and water-quality data.

\section{References Cited}

American National Standards Institute, 2004, Standard test method for radon in drinking water: Annual Book of ASTM Standards, sec. 11, v. 11.02, p. 662-664.

American Public Health Association, 1998, Standard methods for the examination of water and wastewater (20th ed.): Washington, D.C., American Public Health Association, American Water Works Association, and Water Environment Federation, p. 3-37 - 3-43.

Brownlow, A.H., 1979, Geochemistry: Englewood Cliffs, N.J., Prentice-Hall, p. 289-298.

Cardwell, D.H., Ervin, R.B., and Woodward, H.P., 1968, Geologic map of West Virginia: West Virginia Geological and Economic Survey, 2 sheets, scale 1:250,000.

Clark, W.E., Chisholm, J.L., and Frye, P.M., 1976, Water resources of the upper New River basin, West Virginia: West Virginia Geological and Economic Survey and West Virginia Deptartment of Natural Resources, Division of Water Resources, River Basin Bulletin 4.

Cooper, C.K., and Hanna, E.A., 1988, Field water-quality data collected at gaging stations in West Virginia, 1945-1975: U.S. Geological Survey Open-File Report 86-420K, 426 p.

Doll, W.L., Meyer, G., and Archer, R.J., 1963, Water resources of West Virginia: West Virginia Department of Natural Resources, Division of Water Resources report, $134 \mathrm{p}$.

Driscoll, F.G., 1986, Groundwater and wells: St. Paul, Minn., Johnson Filtration Systems Inc., 1,089 p.

Durfor, C.N., and Becker, Edith, 1964, Public water supplies of the 100 largest cities in the United States, 1962: U.S. Geological Survey Water-Supply Paper 1812, 364 p.
Edmunds, W.M., Bath, A.H., and Miles, D.L., 1982, Hydrochemical evolution of the East Midlands Triassic sandstone aquifer, England: Geochimica et Cosmochimica Acta, v. 46, p. 2069-2081.

Erskine, H.M., 1948, Principal springs of West Virginia, a report on the location, discharge, and temperature of the principal springs of West Virginia: West Virginia Conservation Commission and West Virginia State Water Commission, $51 \mathrm{p}$.

Faires, L.M., 1993, Methods of analysis by the U.S. Geological Survey National Water Quality Laboratory-Determination of metals in water by inductively coupled plasma-mass spectrometry: U.S. Geological Survey Open-File Report 92-634, $28 \mathrm{p}$.

Fenneman, N.M., 1946, Physical Divisions of the United States: U.S. Geological Survey, scale 1:7,000,000.

Ferrell, G.M., 1987, West Virginia ground-water quality: U.S. Geological Survey Open-File Report 87-0761, 11 p.

Fishman, M.J., ed., 1993, Methods of analysis by the U.S. Geological Survey National Water Quality Laboratory-Determination of inorganic and organic constituents in water and fluvial sediments: U.S. Geological Survey Open-File Report 93-125, 217 p.

Fishman, M.J., and Friedman, L.C., 1989, Methods for determination of inorganic substances in water and fluvial sediments: U.S. Geological Survey Techniques of WaterResources Investigations, book 5, chap. A1, 545 p.

Freeze, R.A., and Cherry, J.A., 1979, Groundwater: Englewood Cliffs, N.J., Prentice-Hall, 604 p.

Garbarino, J.R., 1999, Methods of analysis by the U.S. Geological Survey National Water Quality Laboratory-Determination of dissolved arsenic, boron, lithium, selenium, strontium, thallium, and vanadium using inductively coupled plasma-mass spectrometry: U.S. Geological Survey Open-File Report 99-093, 31 p.

Garbarino, J.R., and Struzeski, T.M., 1998, Methods of analysis by the U.S. Geological Survey National Water Quality Laboratory-Determination of elements in whole-water digests using inductively coupled plasma-optical emission spectrometry and inductively coupled plasma-mass spectrometry: U.S. Geological Survey Open-File Report 98-165, $101 \mathrm{p}$.

Garrels, R.M., and Christ, C.L., 1965, Solutions, minerals, and equilibria: San Francisco, Calif., Freeman, Cooper \& Company, p. 379-402.

Grimsley, G.P., 1916, Jefferson, Berkeley, and Morgan County report: West Virginia Geological Survey County Report, 644 p., 3 maps. 
Heath, R.C., 1983, Basic ground-water hydrology: U.S. Geological Survey Water-Supply Paper 2220, 85 p.

Hem, J.D., 1985, Study and interpretation of the chemical characteristics of natural water: U.S. Geological Survey Water-Supply Paper 2254, 264 p.

Hobba, W.A., Jr., 1985, Water in Hardy, Hampshire, and western Morgan Counties, West Virginia: West Virginia Geological and Economic Survey Environmental Geology EGB-19, 91 p.

Hobba, W.A., Jr., Fisher, D.W., Pearson, F.J., Jr., and Chemerys, J.C., 1979, Hydrology and geochemistry of thermal springs of the Appalachians: U.S. Geological Survey Professional Paper 1044-E, $36 \mathrm{p}$.

Hobba, W.A., Jr., Friel, E.A., and Chisholm, J.L., 1972, Water resources of the Potomac River basin, West Virginia: West Virginia Geological and Economic Survey River Basin Bulletin 3, $110 \mathrm{p}$.

Hoffman, J.F., 1962, Water and the future of West Virginia: West Virginia Division of Water Resources and West Virginia Institute of Technology Bulletin 1, $16 \mathrm{p}$.

Holmes, D.E., ed., 1995, Counties in West Virginia Blue Book-1995: Chapman Printing, vol. 77, p. 731-846.

Hsieh, P.A., and Shapiro, A.M., 1996, Hydraulic characteristics of fractured bedrock underlying the FSE well field at the Mirror Lake site, Grafton County, New Hampshire, in Morganwalp, D.W., and Aronson, D.A., eds., U.S. Geological Survey Toxic Substances Hydrology Program-Proceedings of the technical meeting, Colorado Springs, Colo., September 20-24, 1993: U.S. Geological Survey WaterResources Investigations Report 94-4015.

Ice, J.R., comp., 1933, New descriptive atlas of West Virginia: Clarksburg, W.Va., Clarksburg Publishing Company, 60 p.

Kozar, M.D., and Mathes, M.V., 2001, Aquifer characteristics data for West Virginia: U.S. Geological Survey WaterResources Investigations Report 01-4036, 74 p.

Kulander, B.R., Lessing, P., Dean, S.L., and Kulander, C.S., 1995, Geology of Stotlers Crossroads quadrangle, Berkeley and Morgan Counties, West Virginia: West Virginia Geological and Economic Survey Open-File Report OF9504, $1: 24,000$.

Lessing, P., Dean, S.L., and Kulander, B.R., 1997, Geology of Great Cacapon and Bellegrove quadrangles, Morgan County, West Virginia: West Virginia Geological and Economic Survey Open-File Report OF9701, 1:24,000.
Lessing, P., Hobba, W.A., Jr., Dean, S.L., and Kulander, B.R., 1991, Relations between warm springs and geology delineated by side-looking airborne-radar imagery in eastern West Virginia: U.S. Geological Survey Water-Resources Investigations Report 88-4096, 44 p.

Martens, J.H.C., 1945, Fifty common rocks and minerals of West Virginia: West Virginia Geological Survey Bulletin 9, $42 \mathrm{p}$.

Mathes, M.V., 2000, Relation of bacteria in limestone aquifers to septic systems in Berkeley County, West Virginia: U.S. Geological Survey Water-Resources Investigations Report 00-4229, 12 p.

Mathes, M.V., Jr., Kozar, M.D., and Brown, D.P., 1998, Summary of ground-water quality in West Virginia: West Virginia Division of Environmental Protection, Office of Water Resources, Ground-Water Program, 54 p.

McColloch, J.S., 1986, Springs of West Virginia: West Virginia Geological and Economic Survey, v. V06A, 493 p.

McColloch, J.S., and Lessing, Peter, 1980, Land use statistics for West Virginia: West Virginia Geological and Economic Survey Environmental Geology Bulletin 18A, 62 p.

McCoy, K.J., Podwysocki, M.H., Crider, E.A, and Weary, D.J., 2005a, Fracture trace map and single-well aquifer test results in a carbonate aquifer in Berkeley County, West Virginia: U.S. Geological Survey Open-File Report 2005-1040, accessed October 26, 2005, at http://pubs.usgs. gov/of/2005/1040/

McCoy, K.J., Podwysocki, M.H., Crider, E.A, and Weary, D.J., 2005b, Fracture trace map and single-well aquifer test results in a carbonate aquifer in Jefferson County, West Virginia: U.S. Geological Survey Open-File Report 2005-1407, accessed January 19, 2006, at http://pubs.usgs. gov/of/2005/1407/

Myers, D.N., and Wilde, F.D., eds., 2003, Biological indicators (3d ed.): U.S. Geological Survey Techniques of WaterResources Investigations, book 9, chap. A7, 163 p.

National Oceanic and Atmospheric Administration, 2002, Monthly normals of temperatures, precipitation, and heating and cooling degree days 1971-2000: Asheville, N.C., U.S. Department of Commerce, National Climatic Data Center, Climatography of the United States no. 81, 46-West Virginia, $23 \mathrm{p}$.

Otton, J.K., Gundersen, L.C.S., and Schumann, R.R., 1993, The geology of radon: U.S. Geological Survey General Interest Publication, $29 \mathrm{p}$. 
Patton, C.J., and Truitt, E.P., 1992, Methods of analysis by the U.S. Geological Survey National Water Quality Laboratory-Determination of total phosphorus by a Kjeldahl digestion method and an automated colorimetric finish that includes dialysis: U.S. Geological Survey Open-File Report 92-146, 39 p.

Perry, L.D., Costain, J.K., and Geiser, P.A., 1979, Heat flow in western Virginia and a model for the origin of thermal springs in the Appalachians: Journal of Geophysical Research, v. 84, no. B12, p. 6875-6883.

Reeves, Frank, 1932, Thermal springs of Virginia: Virginia Geological Survey, Bulletin 36, 56 p.

Reger, D.B., 1924, County reports-Mineral and Grant Counties: West Virginia Geological and Economic Survey, 866 p.

Schad, H., and Teutsch, G., 1994, Effects of the investigation scale on pumping test results in heterogeneous porous aquifers: Journal of Hydrology, v. 159, no. 1-4, p. 61-77.

Schwietering, J.F., 1981, Brief description of ground water conditions and aquifers in West Virginia with annotated bibliography: West Virginia Geological and Economic Survey Open File Report OF-8102, 121 p.

Shultz, R.A., Hobba, W.A., and Kozar, M.D., 1995, Geohydrology and ground-water quality of Berkeley County, West Virginia, with emphasis on the carbonate area: U.S. Geological Survey Water-Resources Investigations Report 93-4073, $88 \mathrm{p}$.

Siddiqui, S.H., and Parizek, R.R., 1972, Application of nonparametric statistical tests in hydrogeology: Ground Water, v. 10 , no. 2 , p. 26-31.

Teideman, C.R., and Hsieh, P.A., 2001, Assessing open-well aquifer test in fractured, crystalline rock: Ground Water, v. 39 , no. 1 , p. $68-78$.

Theis, C.V., 1935, The lowering of the piezometer surface and the rate and discharge of a well using ground-water storage: American Geophysical Union Transactions, v. 16, p. 519-524.

Toth, J., 1963, A theoretical analysis of groundwater flow in small drainage basins: Journal of Geophysical Research, v. 68, p. $4795-4812$.

U.S. Centers for Disease Control and Prevention, 2005, Escherichia coli O157:H7, accessed October 24, 2005, at http://www.cdc.gov/ncidod/dbmd/diseaseinfo/escherichiacoli_g.htm\#What\%20illness\%20does\%20E.\%20coli\%20O 157:H7\%20cause
U.S. Department of Commerce, 1991, Comparison of 1980 and 1990 population data West Virginia and Counties: U.S. Census Bureau, Washington, D.C., 9 p.

U.S. Department of Commerce, 2005, State and County quickfacts: U.S. Census Bureau, accessed October 26, 2005, at http://quickfacts.census.gov/qfd/states/54/54065.html

U.S. Environmental Protection Agency, 2005a, Consumer factsheet on nitrates/nitrites, accessed October 24, 2005, at http://www.epa.gov/safewater/contaminants/dw_contamfs/ nitrates.html

U.S. Environmental Protection Agency, 2005b, List of drinking water contaminants and MCLs, accessed October 24, 2005, at http://www.epa.gov/safewater/mcl.html

U.S. Environmental Protection Agency, 2005c, Proposed radon in drinking water rule, EPA 815-F-99-009, accessed October 24, 2005, at http://www.epa.gov/safewater/radon/ proposal.html

U.S. Environmental Protection Agency, 2005d, Secondary Drinking Water Regulations, guidance for nuisance chemicals, accessed October 24, 2005, at http://www.epa. gov/safewater/consumer/2ndstandards.html

West Virginia Bureau for Public Health, 1984, Water well design standards, ch. 16-1, series 3: West Virginia Bureau for Public Health report SW-255, 9 p.

Wilde, F.D., and Radtke, D.B., eds., 1998, Field measurements, in National field manual for the collection of water-quality data: U.S. Geological Survey Techniques of Water-Resources Investigations, book 9, chap. A6, [variously paged].

Wilde, F.D., Radtke, D.B., Gibs, Jacob, and Iwatsubo, R.T., eds., 1999, Collection of water samples, in National field manual for the collection of water-quality data: U.S. Geological Survey Techniques of Water-Resources Investigations, book 9, chap. A4, [variously paged].

Winograd, I.J., and Robertson, F.N., 1982, Deep oxygenated ground water-Anomaly or common occurrence?: Science, v. 216, p. 1227-1230.

Wyrick, G.G., and Borchers, J.W., 1981, Hydrologic effects of stress-relief fracturing in an Appalachian valley: U.S. Geological Survey Water-Supply Paper 2177, 51 p. 
Appendixes 1 through 3 


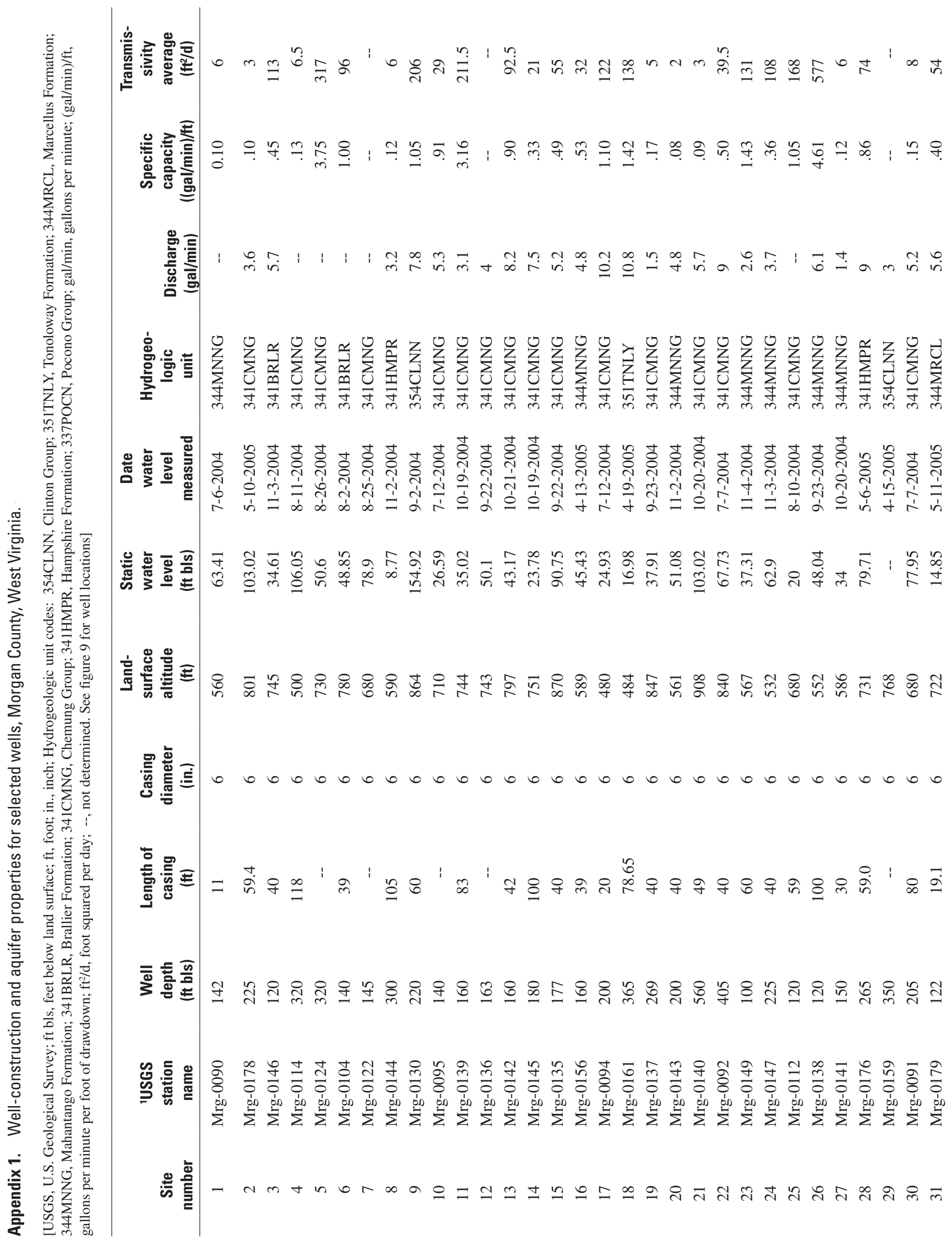




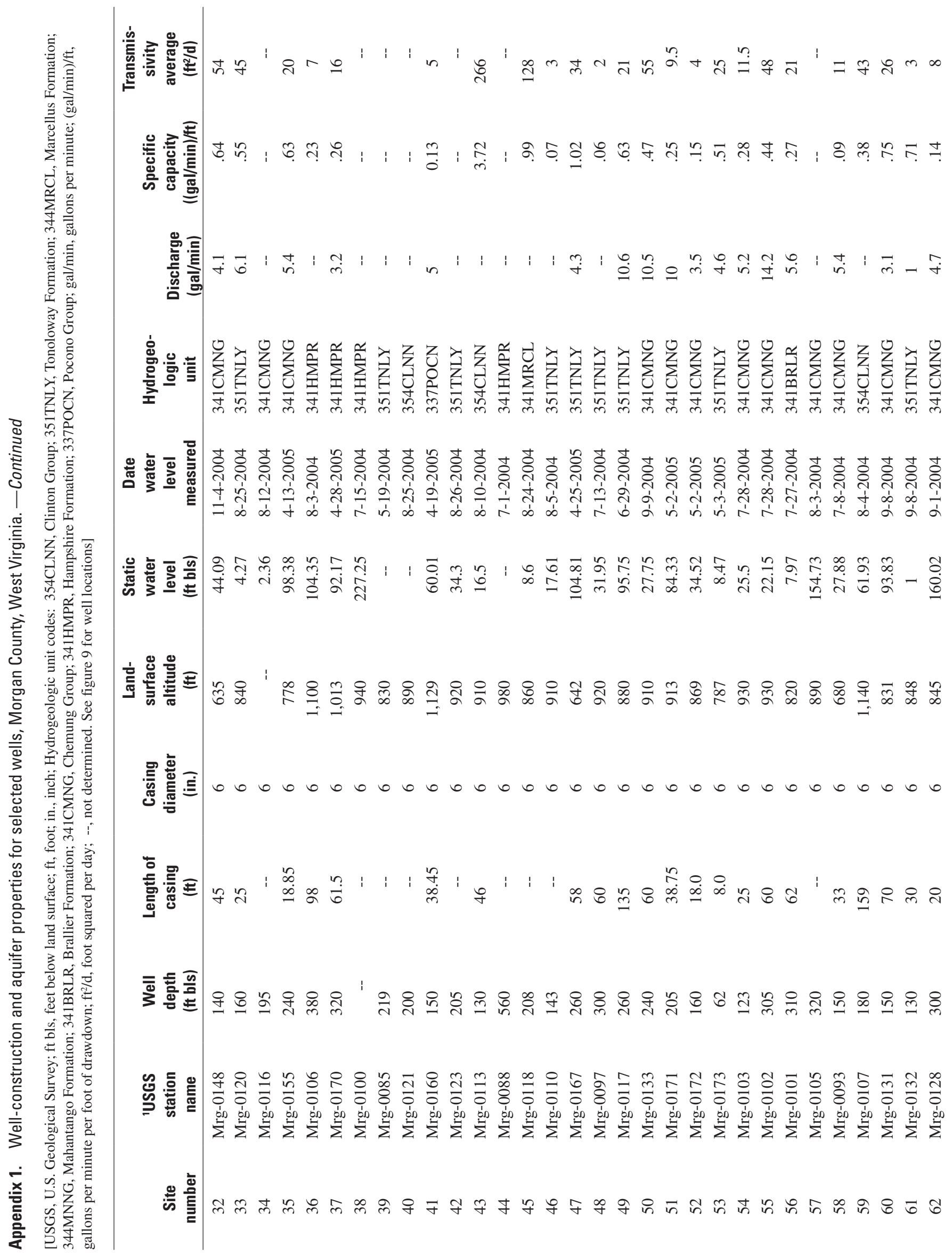




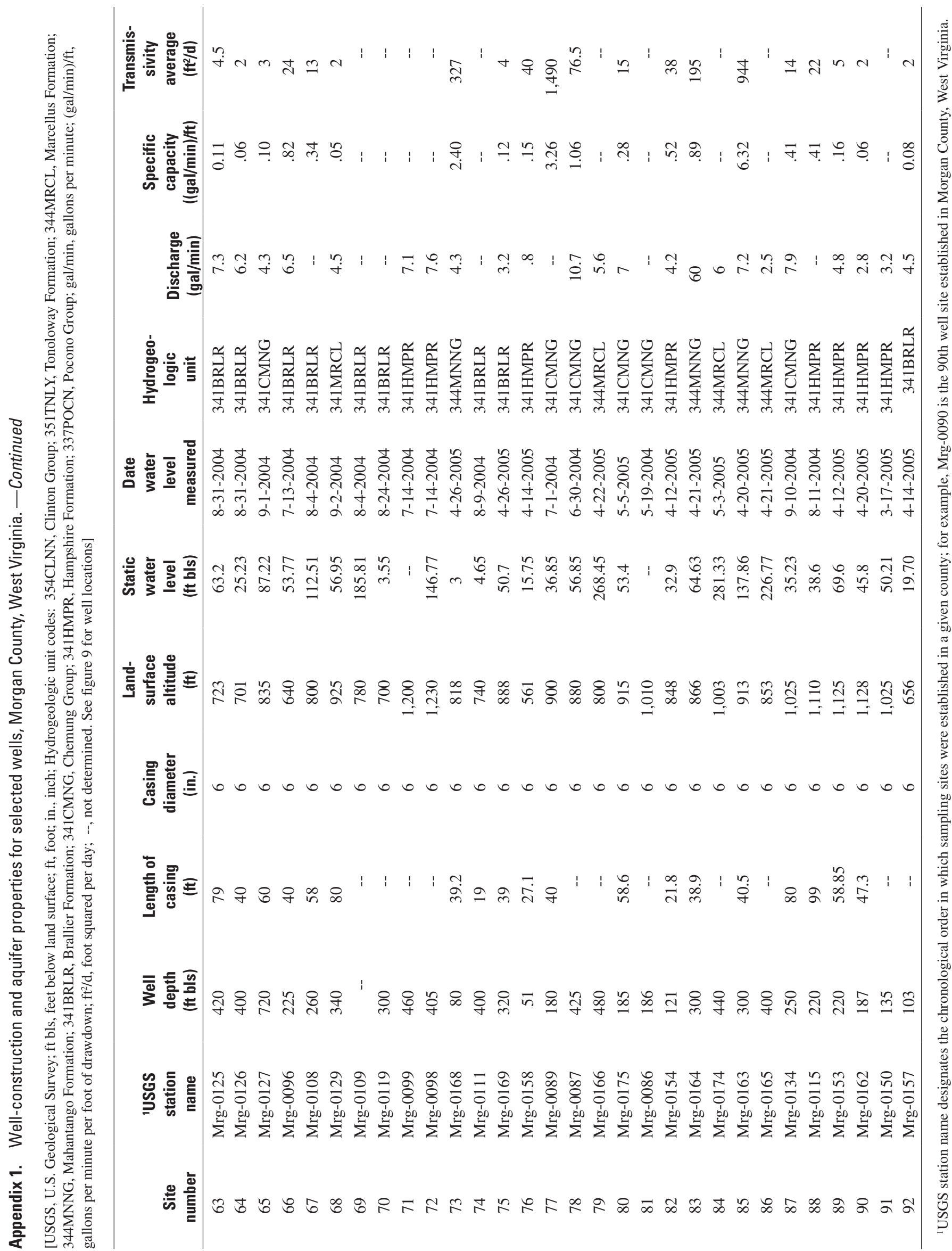




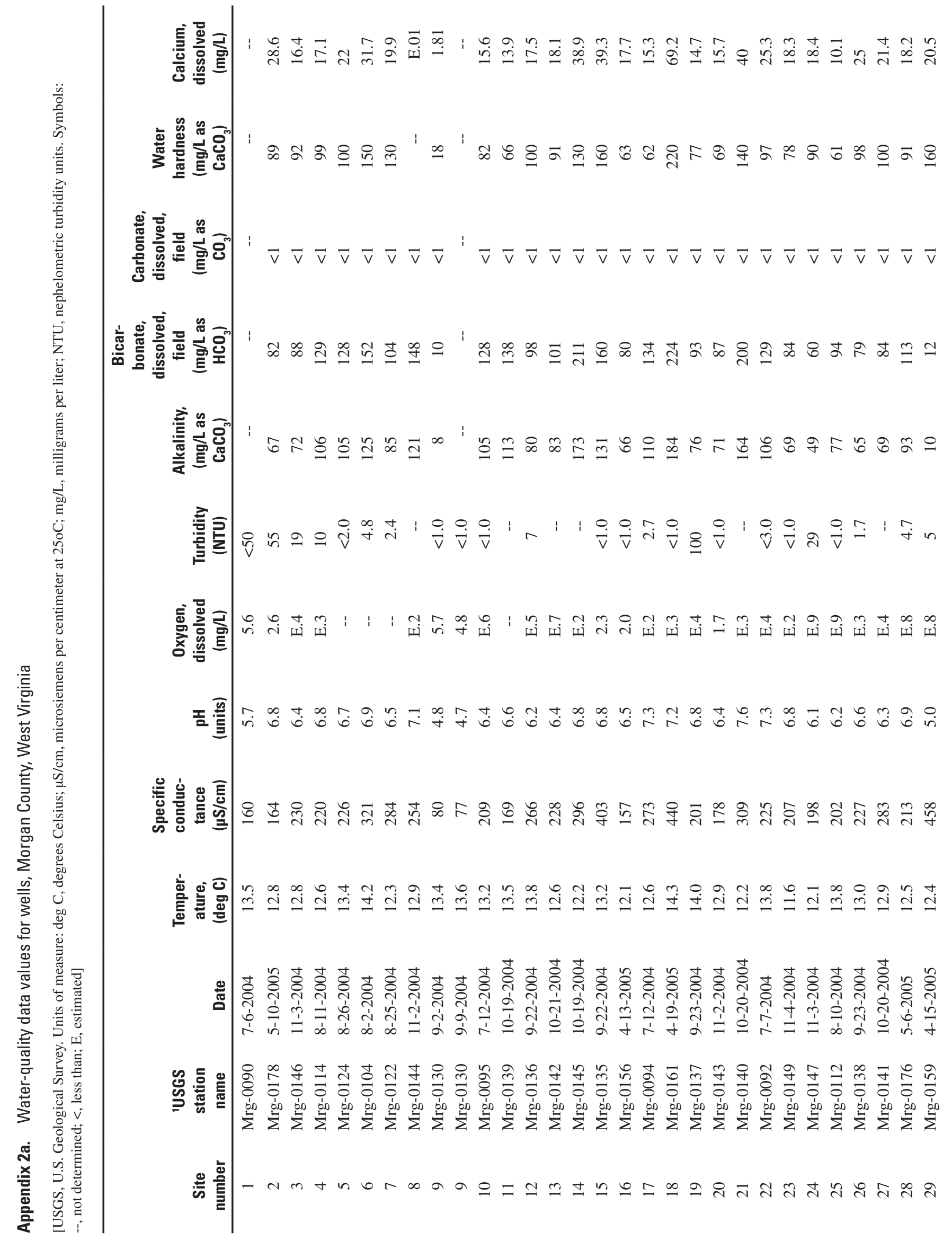




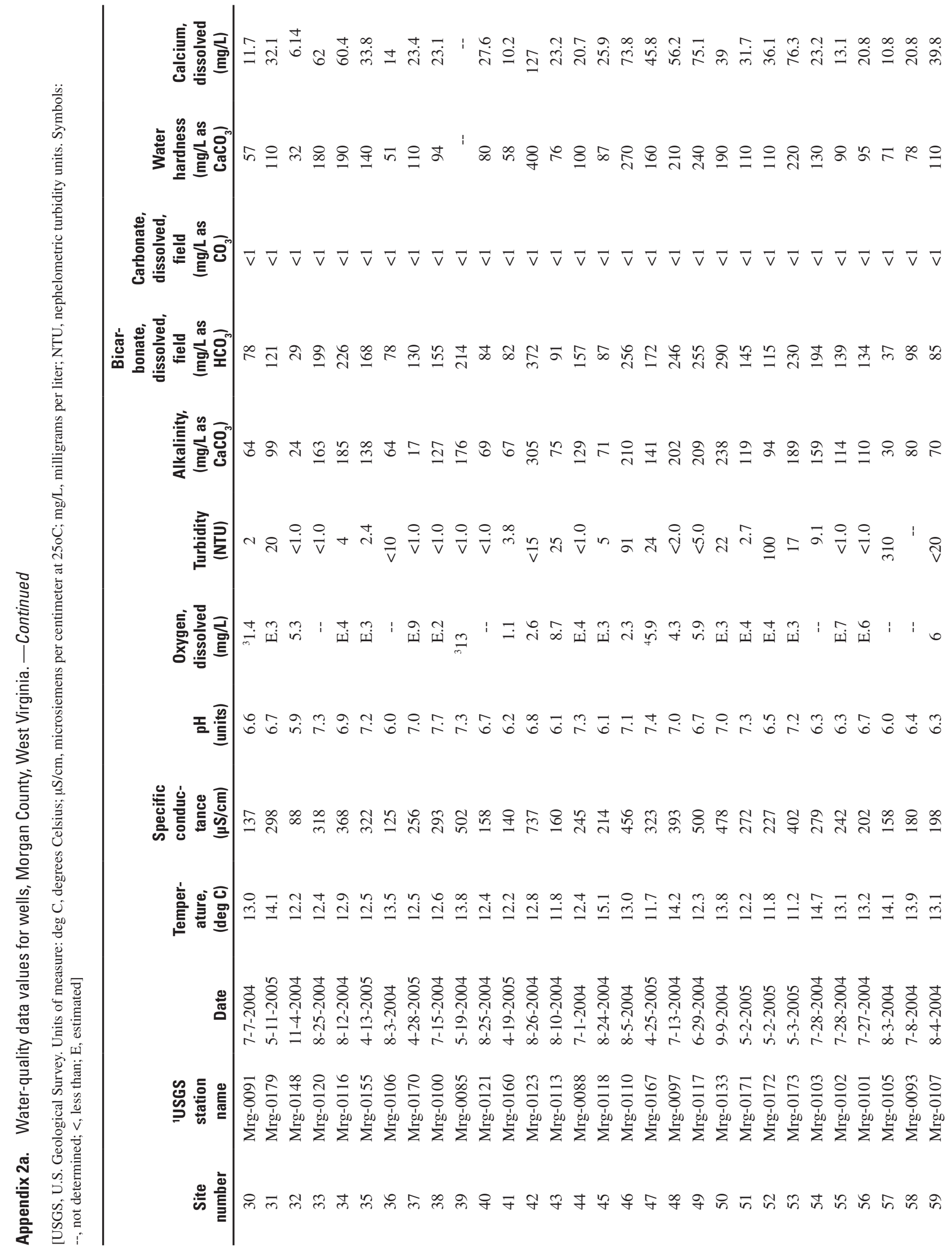




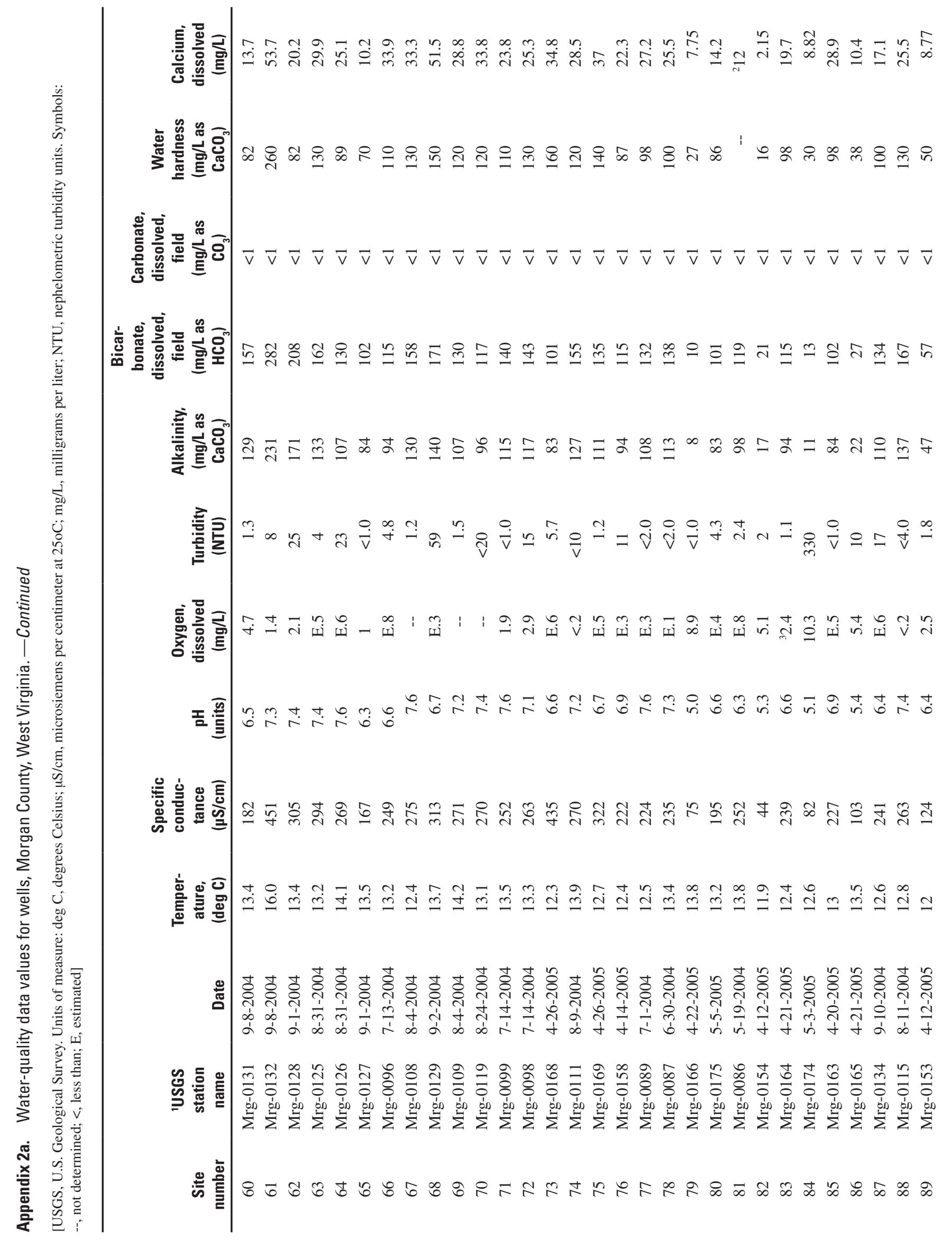




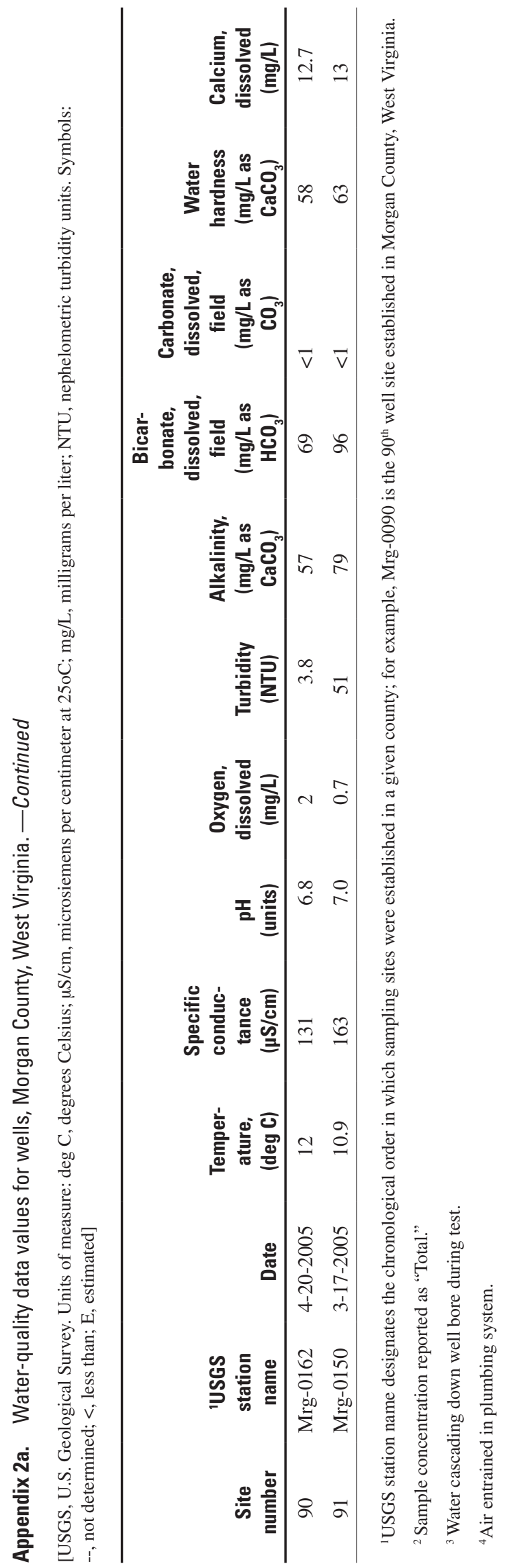




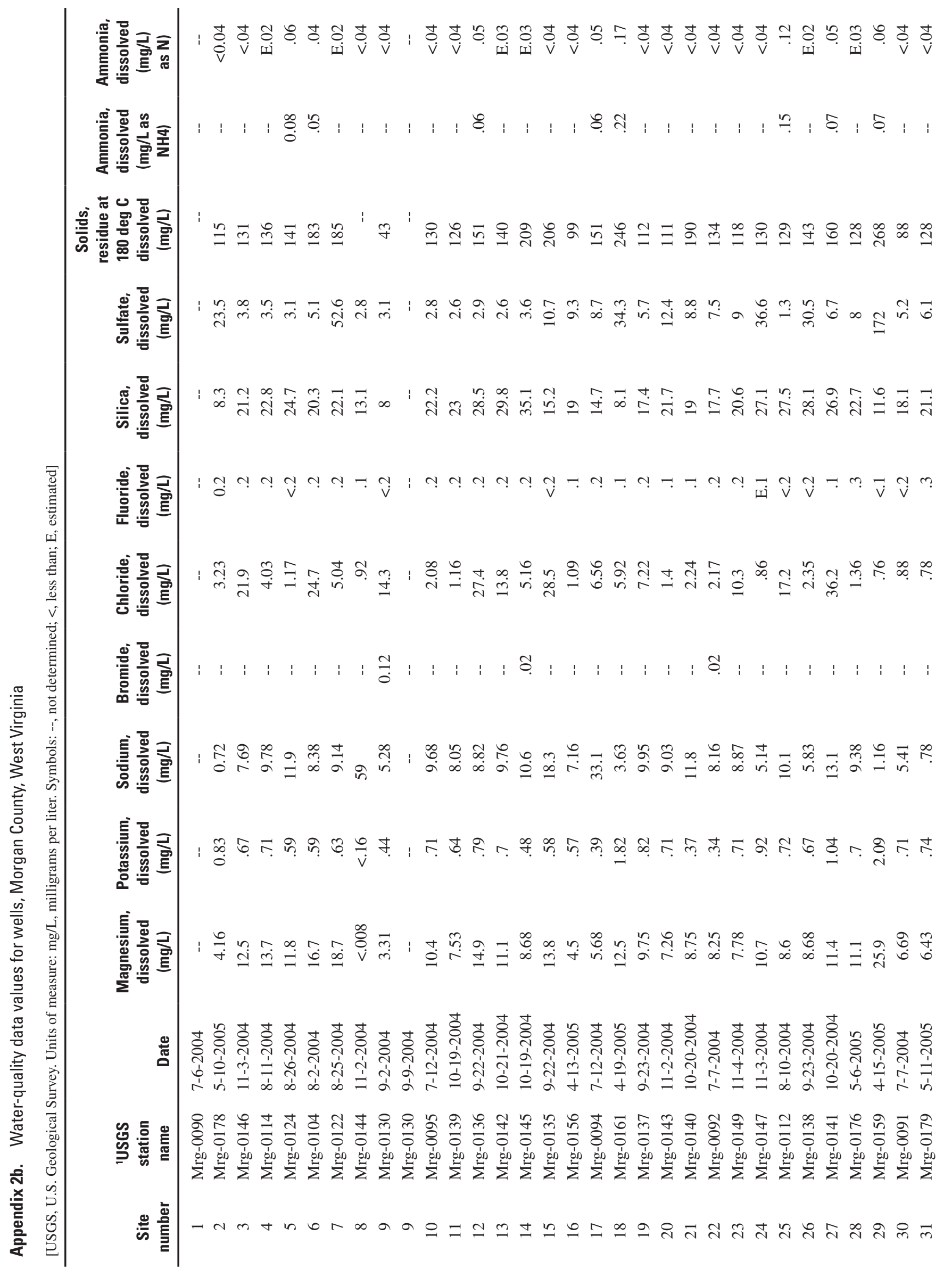




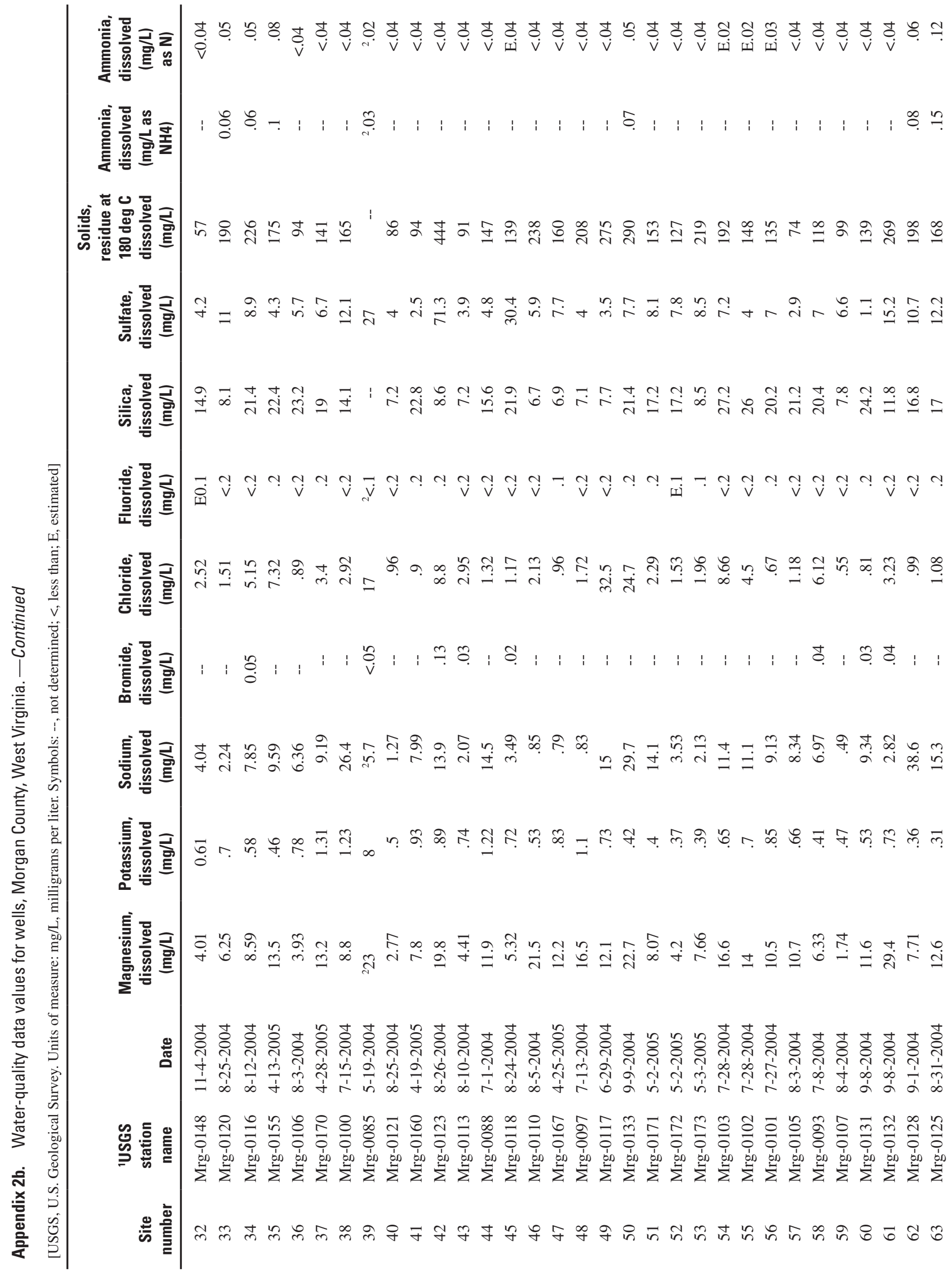




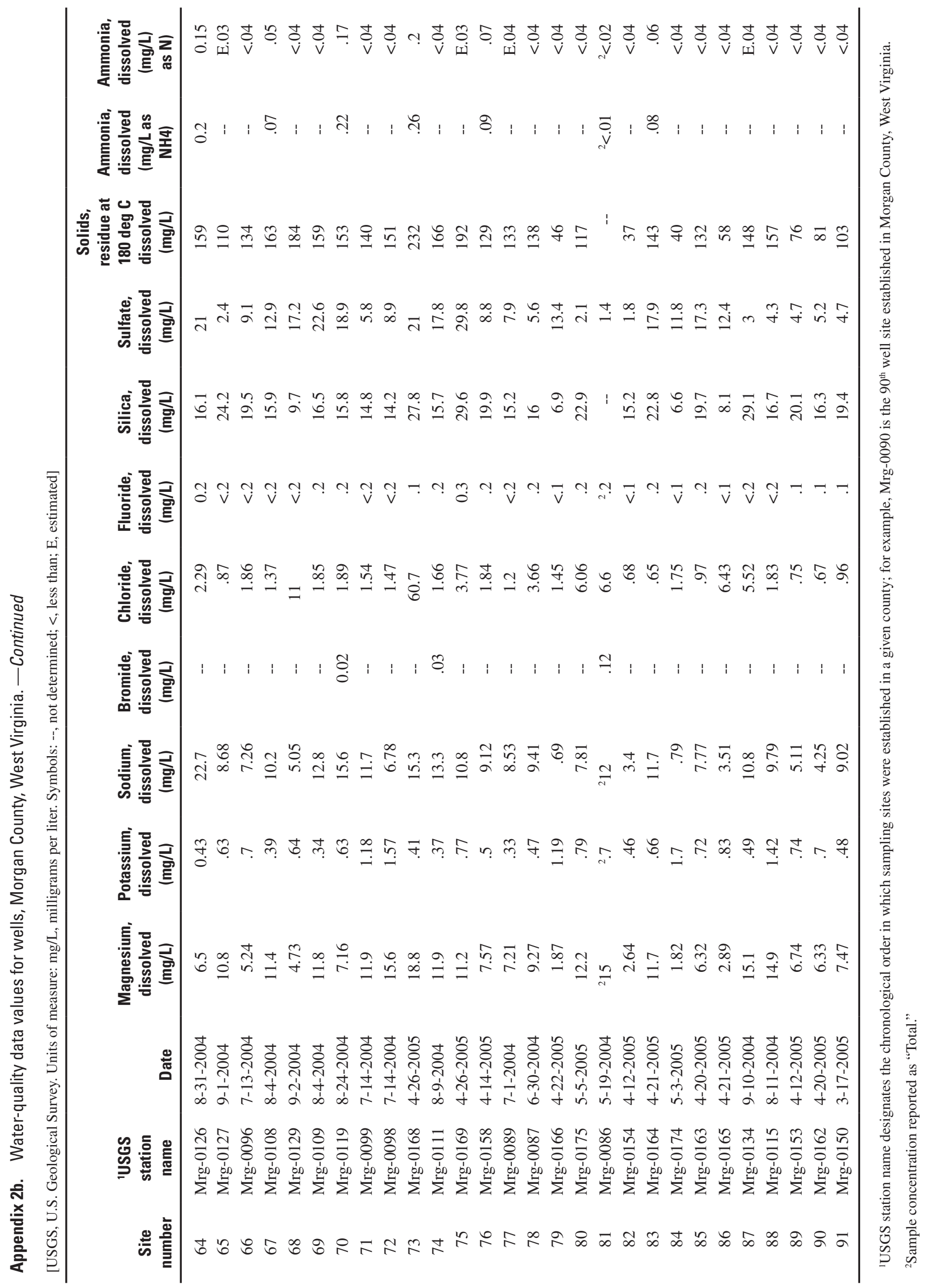




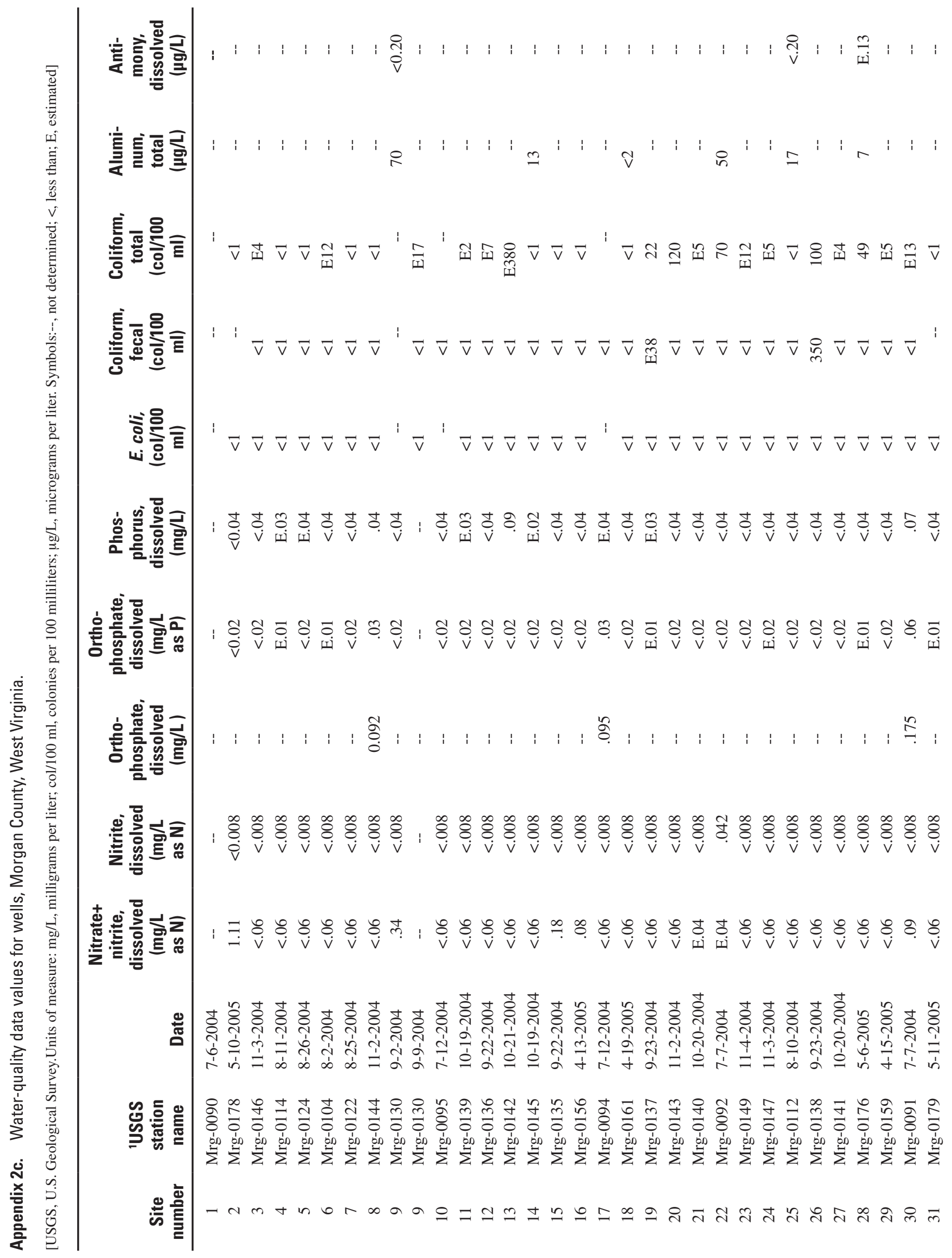




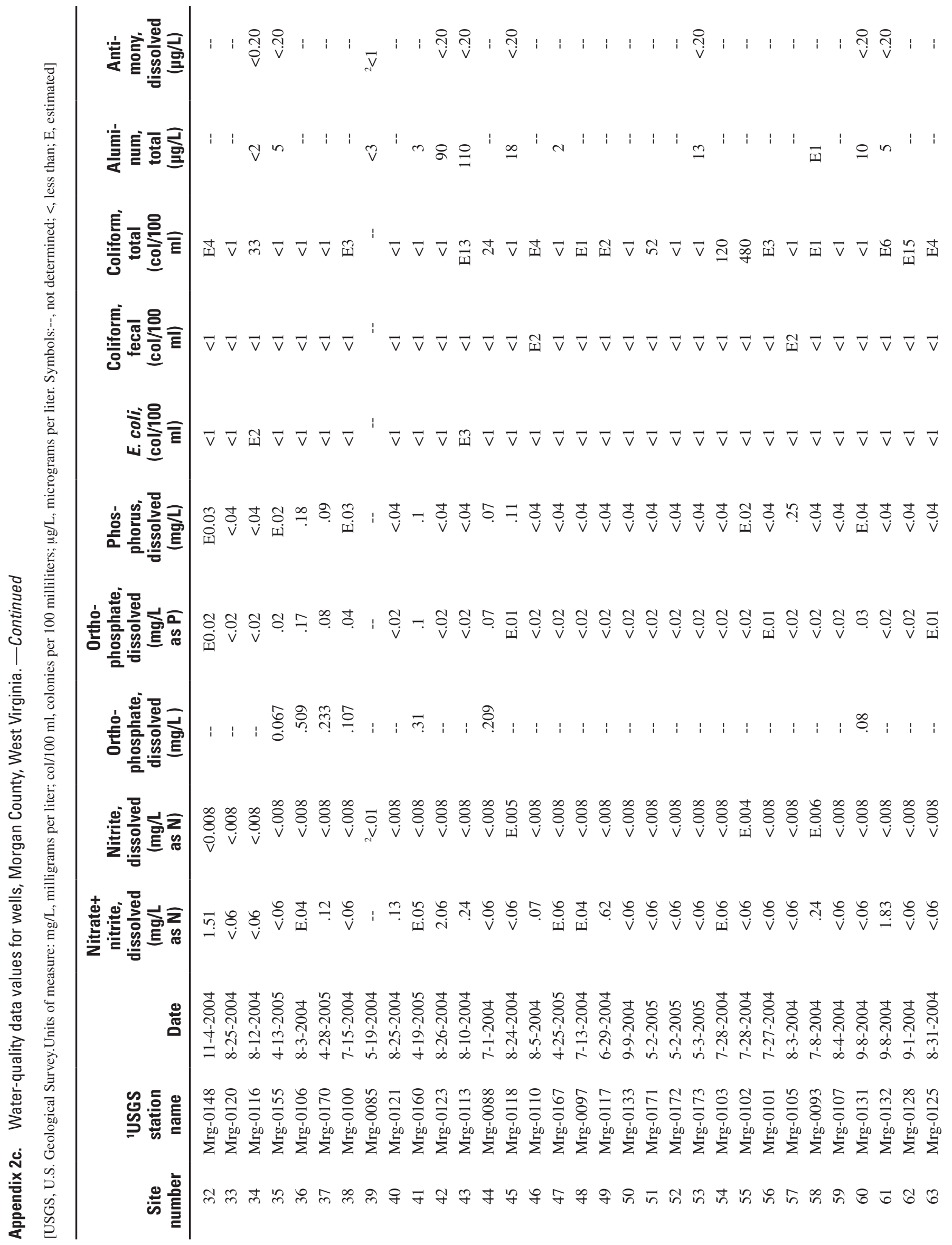




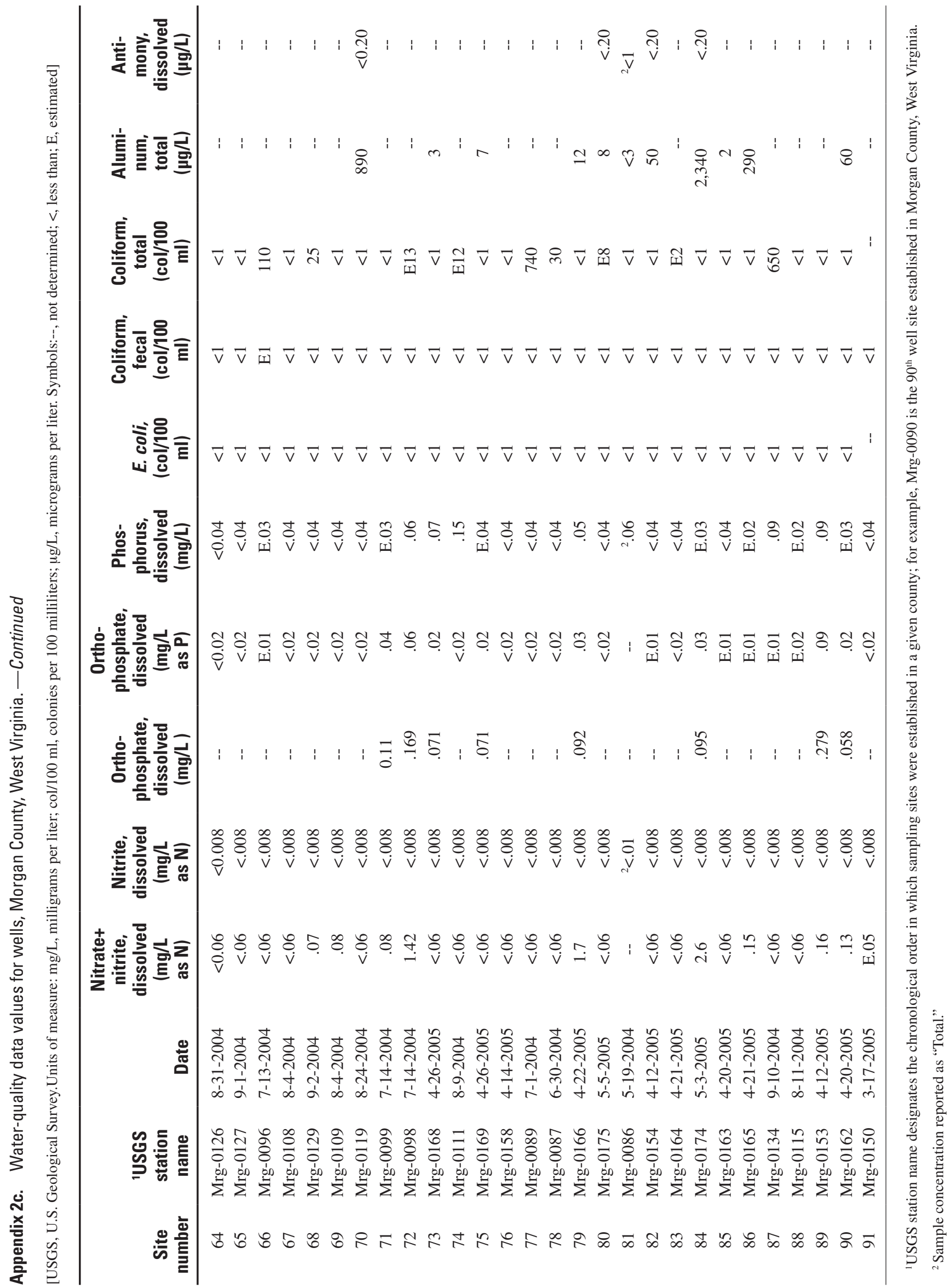




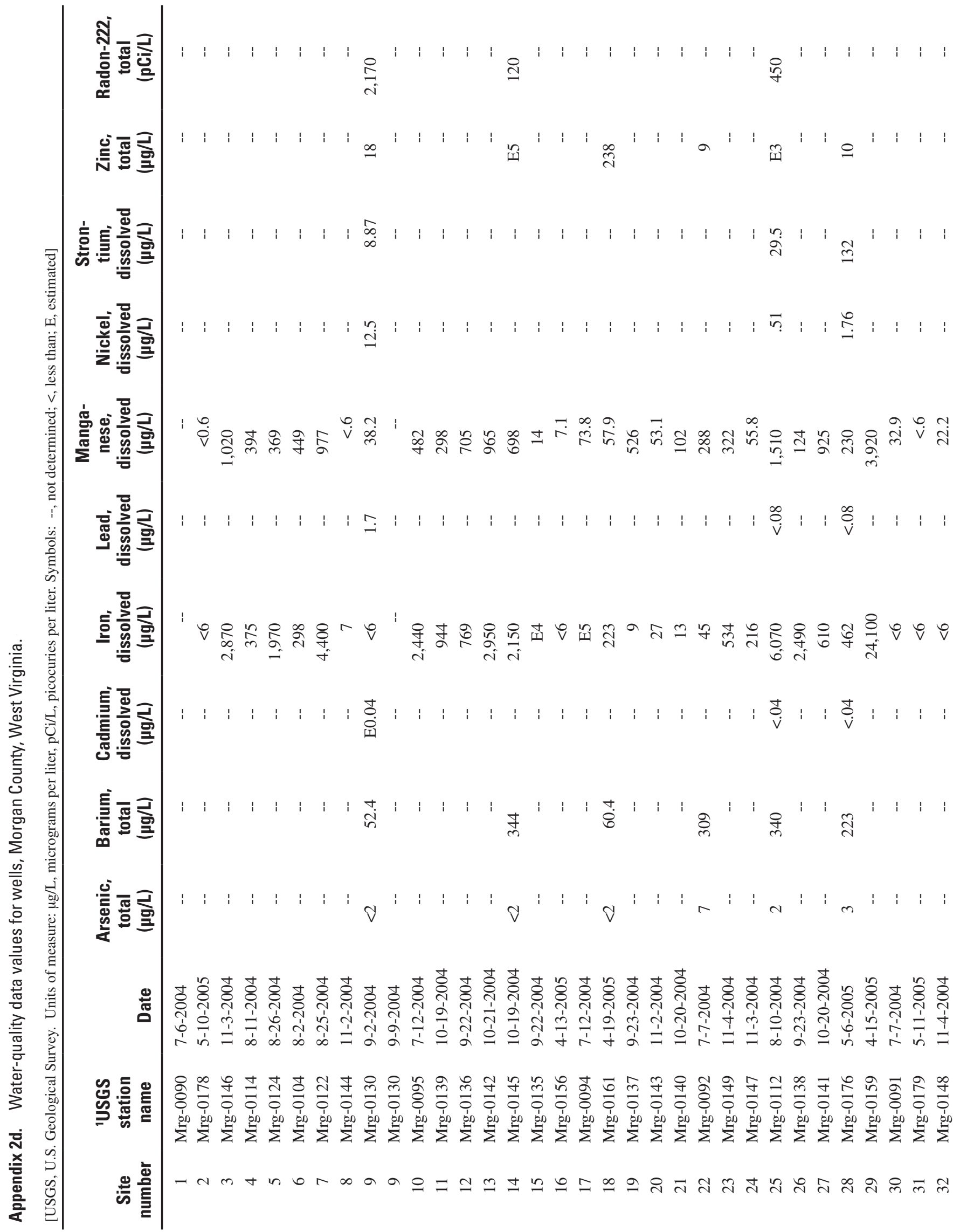




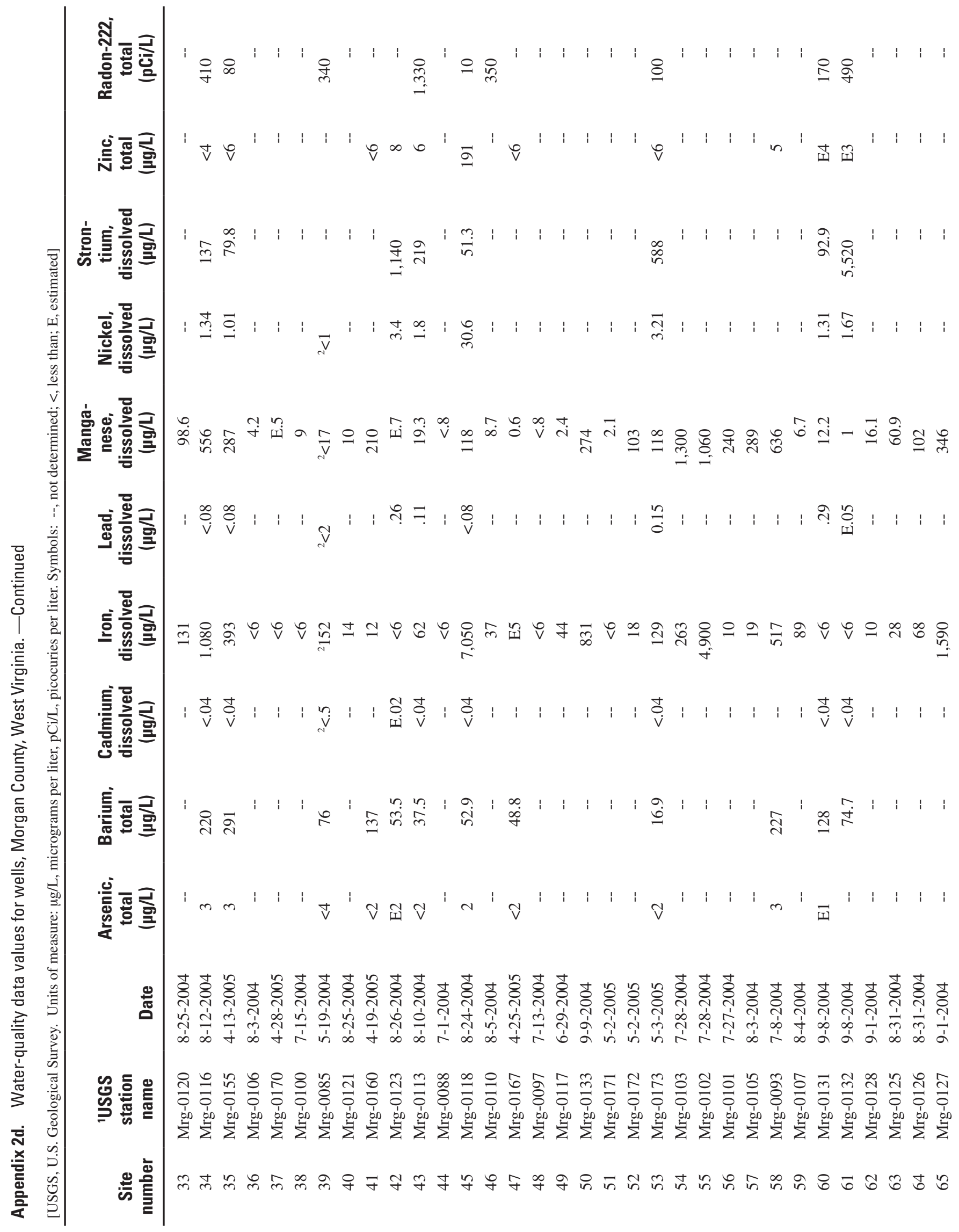




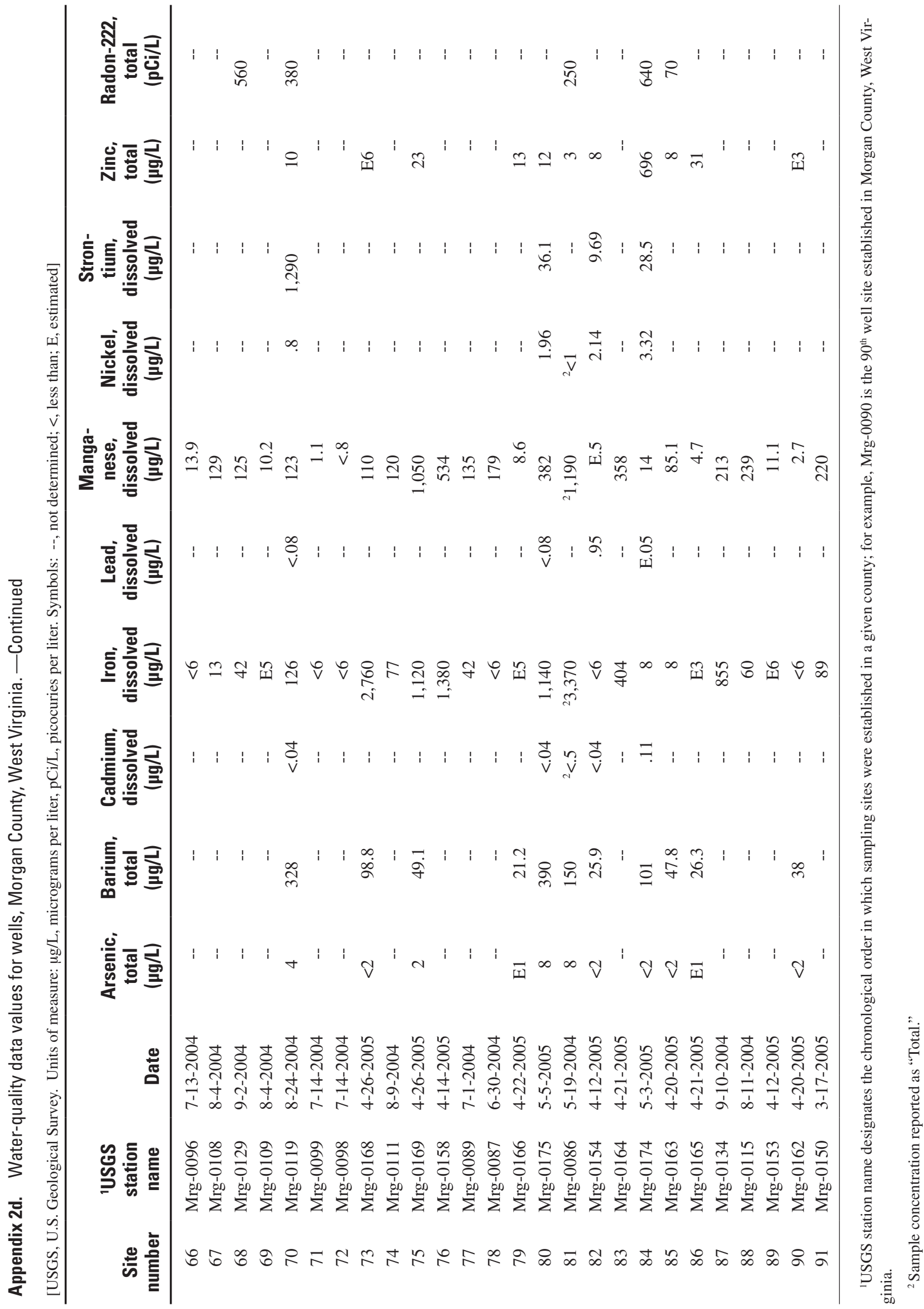




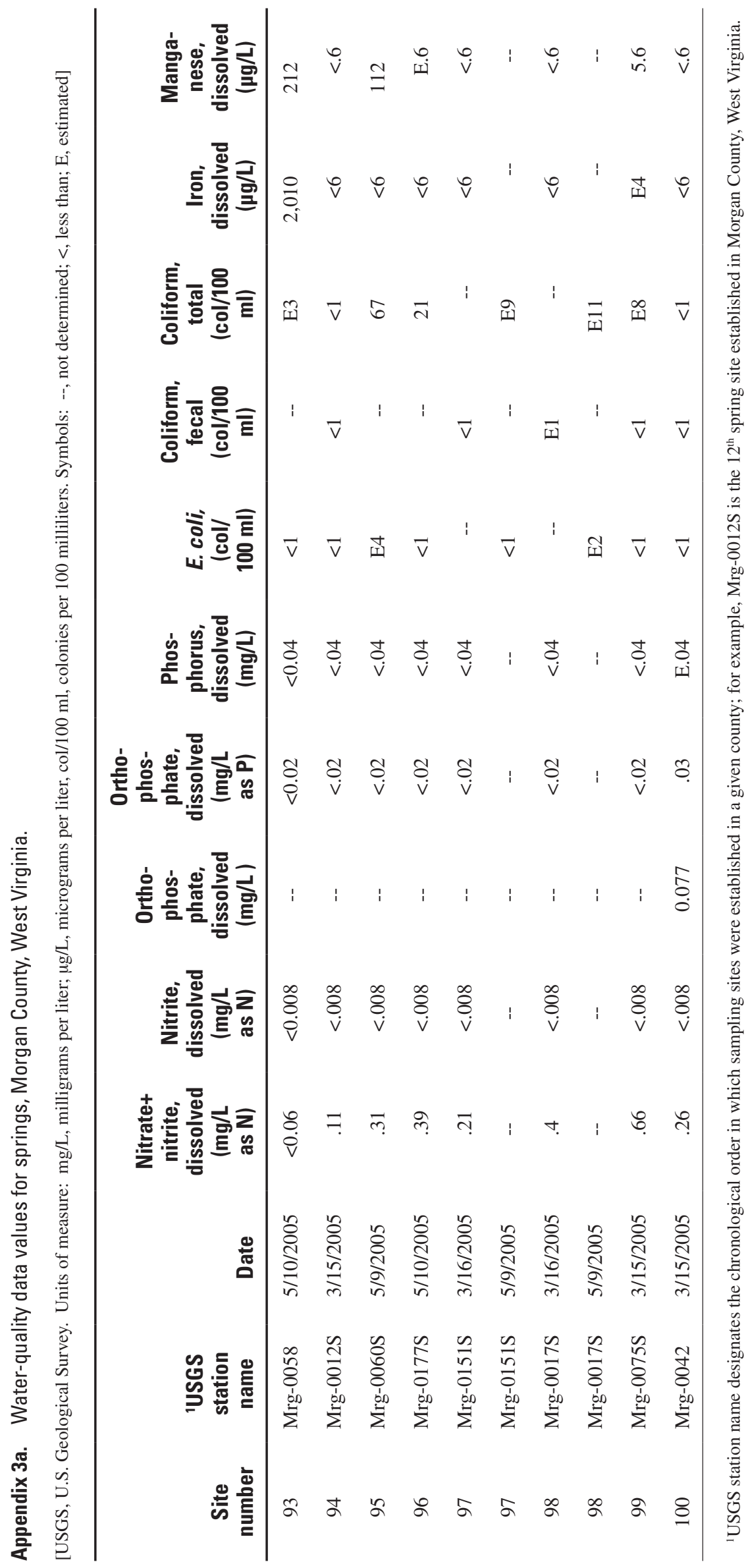




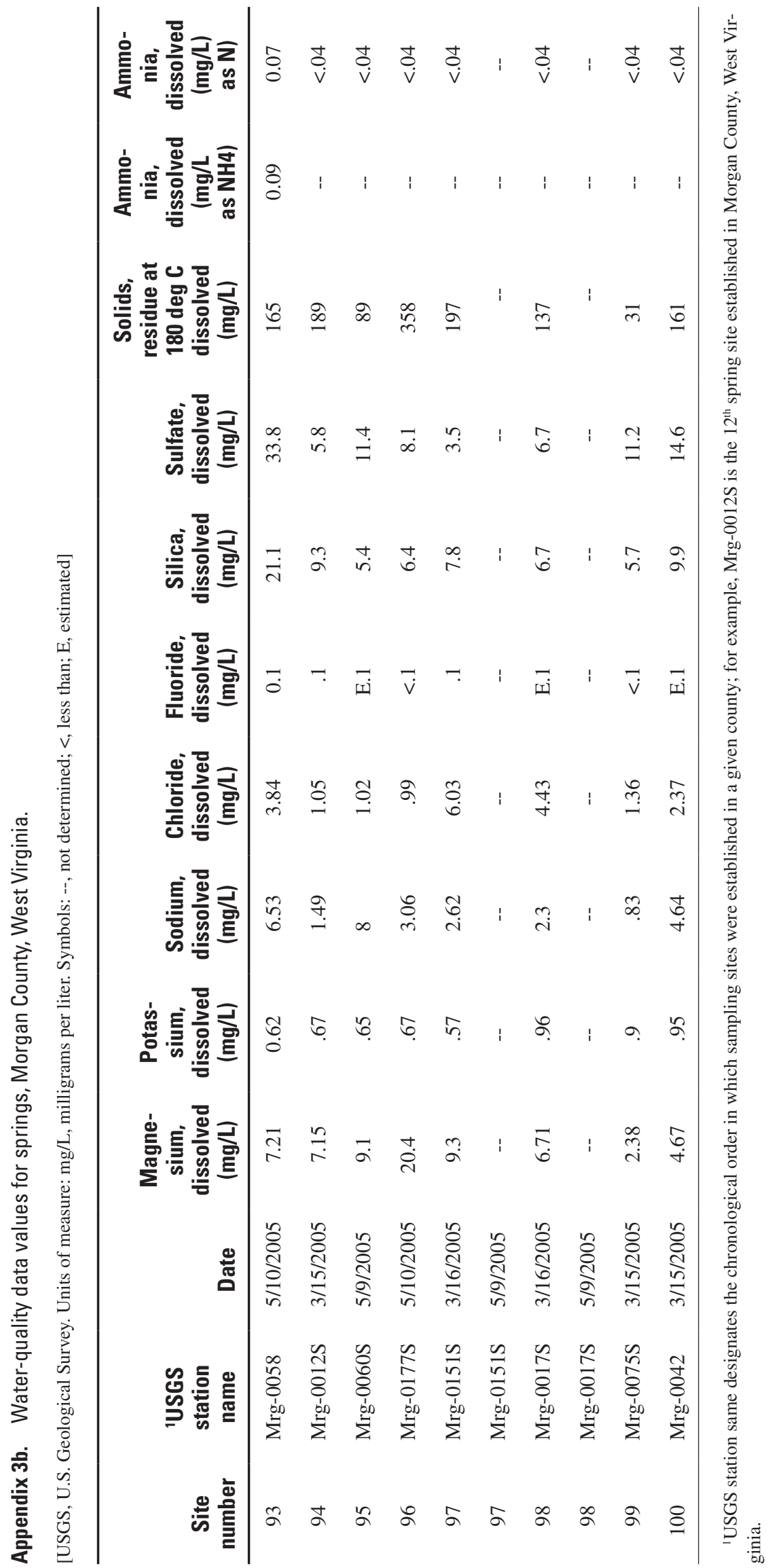




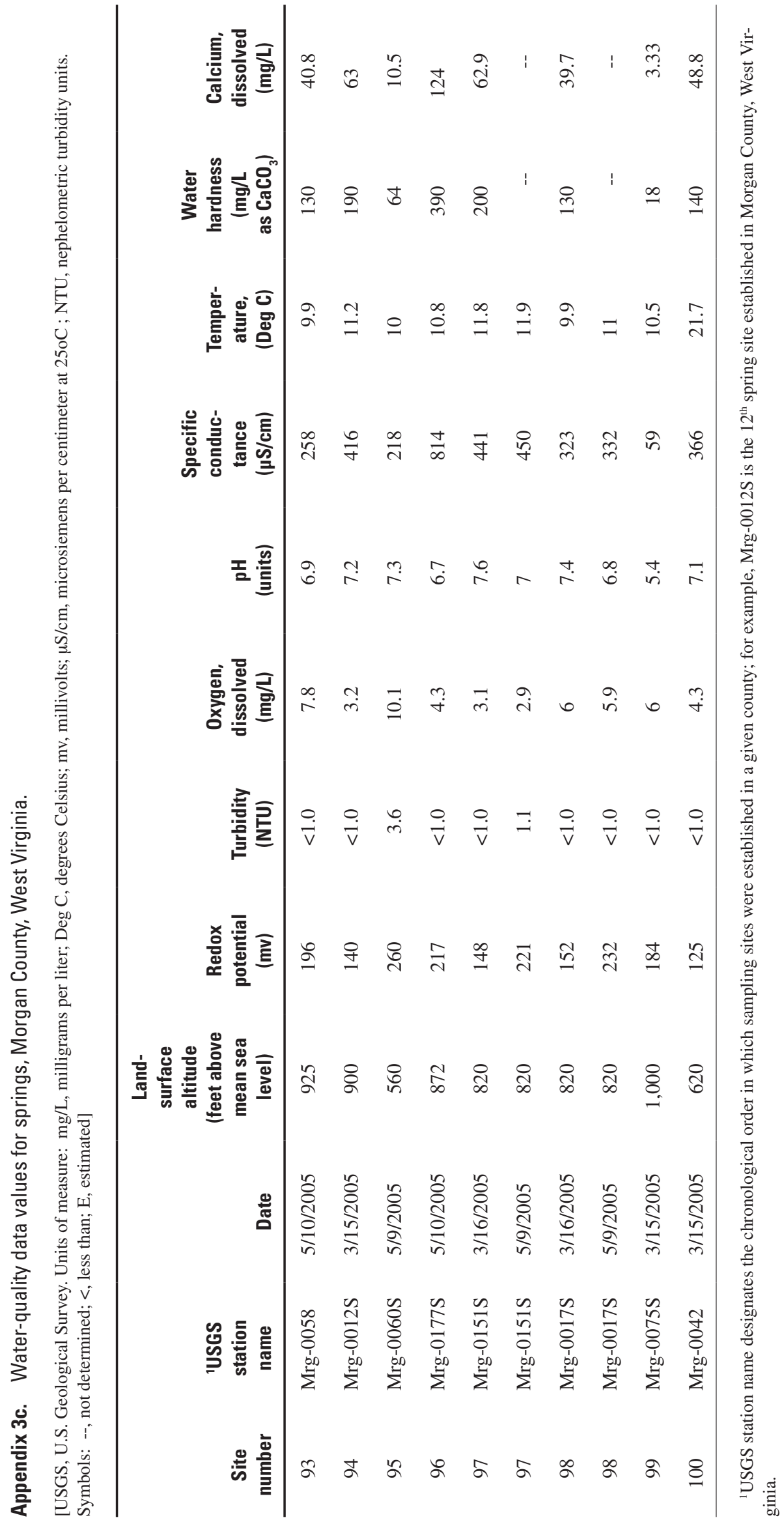





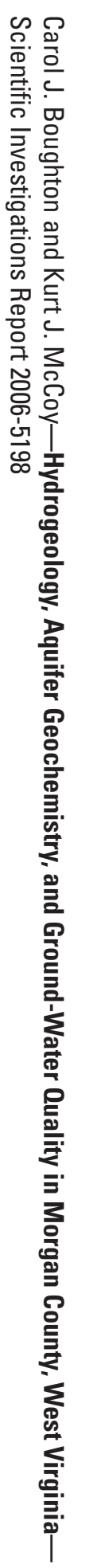

8 Printed on recycled paper 